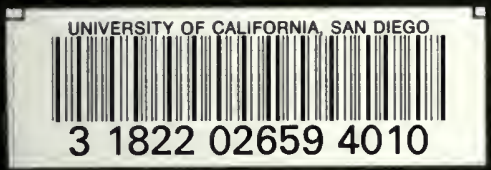

fornia

nal

ty 
Private Library

$=$ of $=$

W. F. Morrison

THE UNIVERSIIY LIBKARY

UNIVERSITY OF CALIFORNIA, SAN DIECO

LA JOLLA, CALIFORNIA

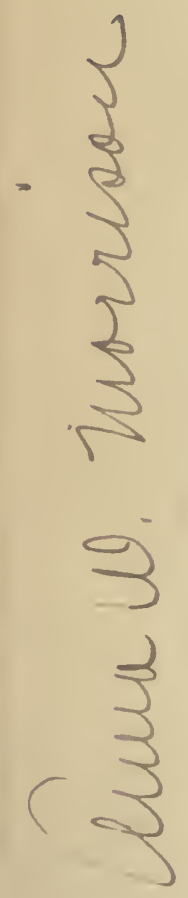




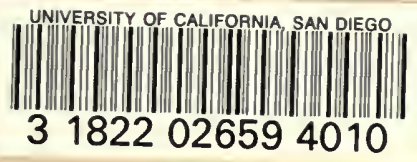


Digitized by the Internet Archive in 2007 with funding from Microsoft Corporation 


\section{THE MORAL CONDITION AND DEVELOPMENT OF THE CHILD}





\title{
The Moral Condition and Development of the Child
}

\author{
BY \\ W. ARTER WRIGHT, Ph. D., D. D.
}

WITH INTRODUCTION BY

TRUMBUll G. DUVALl, B. D., Ph. D.

Professor of Philosophy in Ohio Wesleyan University.

HODDER \& STOUGHTON

NEW YORK

GEORGE H. DORAN COMPANY 
Copyright, 1911

GEORGE H. DURAN COMPANY 


\section{TO MY CHILDREN,}

WHO IN TIIE REALIZATIONS OF LIEE HAVE

ILLUSTRATED THE TKEORIES

OF THIS BOOK. 



\section{INTRODUCTION}

IT was a saying of Borden Parker Bowne that, although a sound philosophy might conceivably be of no benefit to the world, there could be no doubt of the real damage done by an unsound philosophy. With even greater emphasis might one say this of theological dogma; for in no other field has the lust for system at the expense of life borne more bitter fruit. And good men have seldom strayed further than when, under the tyranny of the $a$ priori, they have essayed to extend their deductions to the moral and religious status of the child.

Not the least of the merits of the following discussion, while the author makes no claim of being a specialist in psychology, is his appreciation of the bearing of psychology upon his subject. The point of view and the method of approach adopted by the psychologist bring to light material that may be obtained in no other way. And no safe theological structure can be built without this material. The child-mind and the child-life have their own secrets to tell, and they only learn these who patiently ask what the facts are, and not what the facts ought to be.

But in these chapters there is more serious 
business than exploding unsound dogmas of childhood. The stress seems not so much to be laid upon the child as upon children, and the main plea is the children's plea for a higher standard of parentage and a recognition of the parents' place in the world. And this plea deserves to be heard. The child, summoned into existence by no will of his own, has every right to expect that his parents will undertake the moral burdens of fatherhood and motherhood. He has the right to expect them to maintain the wholesome idealism of the home: for it is the home that gives set and direction to his appreciations and shapes his unconscious tendencies and reasons for doing things. His opportunity for achieving a character-a perfectly fashioned will-depends, in the main, upon the fidelity of mother and father in meeting these conditions. To give the world a healthy-minded, generous youth, one who respects others as he respects himself, who has learned the lessons of self-control and unselfish service, means mothering and fathering the growing soul for almost a score of years, and is the greatest undertaking, as it is the true business of life. The world needs men and women of this sort, and it can not have too many of them. To give it any other sort is to sin grievously against society. Parents who fail at this point, whatever they may have amassed or achieved, have failed in the one thing where failure is irretrievable.

In these later years the psychologist has pro- 
duced abundant material which the theologian has as yet not appropriated. Much of this material bears directly on the problem of the moral and religious education of the child. And the student of social conditions has been daily tracing the vices and crimes of society back to their beginnings in the morally bankrupt home. There is a timeliness in this discussion, therefore, which ought to insure for it the wide interest and thoughtful consideration which it merits.

Trumbull Gillett Duvall.

Ohio Wesleyan University. 



\section{CONTENTS}

I. ORIGINS, - $\quad$ - $\quad$ - $\quad$ - $\quad$ - 19

II. The Child as a Fact Given by Nature, 42

III. The Birth of the SPIRIt, - - 59

IV. Is There a Moral Bias in Human Na- "

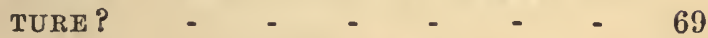

V. HEREDity AND ENVIRONMENT, - 80

VI. Hereditary Sin Disproven by Recovery, 89

VII. Acquired Traits Not Transmissible by

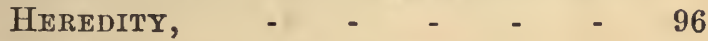

ViII. The Periods of Developarent:

Section 1. First Childhood, - 115

Section 2. Second Childhood, - 120

Section 3. Third Childhood, - 126

Section 4. Later Childhood, - 133

Section 5. The Years that Follow, 142

IX. The Moral Sense, - - - - 145

X. Scientific Era of Religious Instruction, 155

XI. BAPTISM, - $\quad$ - $\quad$ - $\quad$ - $\quad$ - $\quad$ - 163

XII. How Can a Child be Saved? - - 173

XIII. The Birth From Above, - $\quad$ - 178

XIV. WHICH ROAD? - - - - - 195

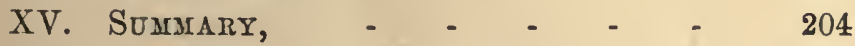





\section{FOREWORD}

Our point of view is that of Divine Immanence. All real forces are God's forces. Undoubtedly. man, and possibly devils, may use these forces in fighting against God. But when we discover how those forces operate in themselves, we know what God has planned. All laws, wherever found, whether biological, psychological, or moral, are God's laws and make known to us the divine method and will. Their origin being identical, they are all equally sacred and obligatory. I have never found myself in the predicament where a psychological law contradicted a revealed law, and hence where I must eliminate one or the other; but I do find aid from the biologic or psychologic law in the interpretation of the revealed law. Assuming the divine origin of both, I am bound to find an interpretation of both that harmonizes and not to leave them in apparent contradiction.

The "Boy Problem" is solved usually before it is attacked. If it remains until it becomes acute, it is never solved. Unless solved in childhood, it is insoluble except in rare cases. A youth is confessedly difficult to influence and guide. He has come to the period of self-guidance 
and independence, and is suspicious of all attempts to control him by others. He is influenced by the "gang" more easily and naturally than by those who are in places of authority. Unless he has already had safe principles instilled into him, by which he may safely direct his own course, the battle is probably already lost. The insuperable difficulty is not so much with the boy -for there is a pretty sure law of his characterformation-but with the parent who will not awaken to the problem until it is no longer soluble. The saddest hour that ever comes to a parent is that hour when he must reap the fruit of the neglect of the training of his child. It is far darker than the hour when the body of a loved child is consigned to the grave.

"How sharper than a serpent's tooth it is to have a thankless child!" A father said to me not long ago: "I do not know what to do with my boy. He left home this morning after breakfast and probably will not be home before midnight. I do not know where he is, or what he is doing. He has no respect for me." He seriously discussed turning him over to the State to be controlled in one of its institutions. Parents quite usually listen in incredulity when a pastor points out to them in advance that such an hour is coming. Afterwards, when it has come, they make frantic appeals for aid; but it is usually too late. God's laws of child-training can not be violated or neglected by Christian peo- 
ple with any greater impunity than His general laws by other people. That which they sow they must reap just as others do.

The practical bearing of the discussion in the following pages should be largely in the direction of a different approach to the religion of children. The traditional door of entrance for them into relations with God has been through the teaching that they have a sinful nature of which they must be conscious and make confession, and concerning which they must repent. It is proper here for me to point out the sad consequences of that teaching in my own experience. As I look back upon it now I am certain that it was wholly mistaken, and that my childhood was greatly wronged. I say this without attaching blame to any one; for all were under the dominion of a theory that was unquestioned at that time, and which still widely prevails.

I grew up in a home that was Christian in a very genuine sense. My father was a faithful preacher of the gospel for nearly fifty years. My parents' religious leading was always consistent and genuine. It was not their direct solicitude concerning me that caused the misdirected efforts; but rather the influence of the religious teaching heard on all hands, in pulpit and Sunday school and religious gatherings.

Very early, at most at seven years of age, I wanted to commence the religious life, and pre- 
sented myself again and again as a seeker during four or five years. Among the people who talked to me on the subject was a certain preacher, who was often in our home for some years and who never missed an opportunity of urging me to become a Christian. He was a very zealous man, though probably not very learned or wise. I do not know why I should have come to dread the contact with the man; for his suggestion was in line with all the teaching of those days, and I had not rebelled against it, but rather had striven to realize it. It must have been some instinct, better than my teaching or my thought, that gave me an aversion to his suggestions, and to him personally-an instinct that resented the idea that I was not a Christian. I do not remember that the matter was strongly urged upon me by any other person. So far as my home was concerned, I was treated as though I were a Christian, though this practice was not supported by any doctrinal teaching. In seeking for an experience, I never made the least headway. I can remenber the instructions given to me at the altar, that I should repent of my sins-not specific sins, but of sin in general. I was taught that I should feel that I was a sinner, and I tried to have a sorrowful feeling. But it was of no use. I could not enter into the experience portrayed, and finally, when about eleven or twelve years of age, I became discouraged, and for two or three years entered into some sinful habits. I thought that I 
had adopted the Calvinistic doctrine of the nonelect; that I was one such; that there was no salvation for me. I became hardened and rather careless in some matters. I say that I thought that I had adopted this doctrine. I would have explained my situation at that time by so saying. I very much doubt now that it was a real conviction. It did not take me long to discard it, at least, when a way into the Christian life was at last clear before me.

All this childish instruction I now believe was an entire mistake, and seven years of my life were spent in religious darkness, with great risk that my alienation from Christ should become permanent, by the teaching that I needed an experience of repentance from sin, and a conversion. I believe this without assuming that my childhood life was without fault. I at least was not in a state of rebellion against God. I wanted to be counted among His followers. Actual sin should have been dealt with as individual faults, as we deal with all of God's children, and not as a proof of a depraved heart.

If the following discussion shall save some from such years of suffering, and prevent such risks as I passed through, it, no doubt, will be amply justified.

W. Arter Wright.

Deiaware, Ohio, June 1, 1911. 



\title{
CHAPTER I
}

\author{
ORIGINS
}

From the standpoint of modern science nothing can be more absurd than the discussion of Original Sin by Augustin as he comes to deal with sin in its action in our animal nature. That which the scientist regards as the necessary impulse of nature, wisely and divinely arranged for the continuance of human beings on the earth, and the provision for their health and well-being, Augustin assumes to be the result of the introduction of sin. This sinfulness may be assumed as axiomatic from his point of view, because the functioning of nature is attended with fleshly gratification; as if the hatefulness and painfulness of an action were the only conditions that would save if from being sinful. He seeks to deduce from Scripture hints as to the pleasureless working of human nature before sin had entered the world.

The assumption that sin only is pleasurable is unfounded; the necessity of explaining away the gratification is forced; and any such interpretation of Scripture must be erroneous, unless we assume that the Bible was written by some authority as inimical to modern science as Augus- 
tin himself. This latter assumption I believe is entirely unnecessary; but as I turn away from. it, I turn away with equal decision from the whole traditional intepretation of human nature's relation to sin.

One can not read the literature of the day when the traditional doctrine of human depravity arose without having the strong suspicion that it all originated from the assumed sinfulness of the act of human procreation. It grew up in the same atmosphere which produced the celibate clergy and the immaculateness of the virgin lifetwo of the most prolific sources of the corruption of Christianity, as well as being doctrines of unbounded offense against the spirit of modern science. The purity of the race, or the excellence of any one of the races, is now held to be identified with the power of reproduction as with no other one human element. Biologically, virginity is the fundamental sin, and Nature has sought to protect living beings against it by her strongest passion. Race senility accompanies the vices which destroy this fundamental physical virtue. Race suicide is the deepest, the most prolific, the farthest-reaching vice of a boasting civilization. When religion strikes at the fundamental human function of reproduction as in its very nature sinful, it flies in the face of all modern thought and conviction. We owe it to our faith to eradicate this so fundamental error and offense, not only from our creed, but the least suggestion of it 
even from our consciousness. This monstrous barnacle is not of the essence of our faith. It must be as offensive to God as it is to truth.

It was the view of Schopenhauer that the "essential element in human nature, and finally in the whole of reality, consists in a mysterious impulse toward life, a blind restlessly struggling will wholly unguided of reason. . . . In nature intelligence yields place entirely to this vital impulsion; such knowledge as is here developed merely subserves the interests of self-preservation." (Eucken: "Problem of Human Life," 511.) This will or impulse of Schopenhauer may be compared to what Augustin called sin in human nature. Schopenhauer regarded existence as a calamity. If Augustin had frankly taken the view that human existence was to be deplored, then it would have been consistent to regard the passion toward reproduction as sinful.

If the doctrine of Original Sin grew from such a root as this, then the whole subject needs to be restudied and restated in the light of what we now know of human nature, conditioned as it is by a physical or animal foundation.

Augustin was orthodox and Pelagius was heterodox; but from the view of the modern student Pelagius's statements are verbally nearer the truth than are those of Augustin. This may be the mere accidents of words that have in reality changed their content. It is altogether likely that Pelagius was not so near modern belief as his 
words may indicate. At any rate we are not to disavow what is now evident, just because the form of words was once pronounced heretical. The words no longer convey the same conceptions that they did as used by Augustin. The whole point of view has been changed. It is no longer enlightening or helpful to affirm or deny some of the old points of controversy; e. g., it is approaching the subject under a wrong presupposition to affirm or deny that infants should be regenerated in order to be admitted into the Kingdom of God. It is not illuminating to affirm or deny that "children are in the same state in which the first man was before transgression;" and yet this was precisely the point of the Pelagian controversy. The whole subject of the moral condition of the child has to be restudied from the point of view of modern biology and psychology.

The Traditional View Was Too Materialistic.

Harnack points out that one of the early developments of Christianity, a contribution of Orientalism on the soil of Hellenism, was the "depreciation of the world, the contention that it were better never to have existed, that it was the result of a blunder, and that it was a prison, or at least a penitentiary for the spirit." Another development was "the conviction that the connection with the flesh ('that soiled robe') depreciated and stained the spirit; in fact that the latter would inevitably be ruined unless the 
connection were broken or its influence counteracted." ("Mission and Expansion of Christianity," I, 32.) We thus see that the later deductions concerning the sin inherent in the flesh, which are noted in Augustin's teaching and since, may have been a contribution of Oriental mythical thought, brought under the formative power of Hellenizing thought-something read into Christianity, and not a just product of it. Augustin thought of sin as something physical, something inhering in the flesh, and did not confine it to the will and the moral nature. To him a "movement" of the flesh could be a sin, even when that "movement" was subjugated by the will and denied gratification. This is as absurd as to affirm sin of the animals of the field or the interaction of chemical forces.*

- While Augustin has stated more explicitly than any other the doctrine of the medieval Church concerning the evil nature of the "movements" of the flesh, yet there is evidence that his belief far antedated him. It can hardly be traced to the Jews in the form in which he held it, for they have a saying in the Talmud which reflects a different scntiment. It says: "These four are reckoned as dead-the blind, the leper, the poor, and the childless." But the sentiment was so strong in the time of Origen, who lived from 185-254 A. D., that in his youth in his aspiration for purity he mutilated himself for the Kingdom of Heaven's sake. (Eusebius H. E., vi, 8.) If any of the fathers of the Church deserves to be styled the "greatest of the fathers," it was this Origen, undoubtcdly the most learned of them all. The volumes that he wrote are said to have been numbered in the thousands, and his impress on the Church has never perished.

Mcanwhile the doctrines of virginity and celibacy grew apace and the foundations of marriage were undermined, leading to the greatest crimes and scandals that ever disgraced the Christian Church. For many centuries marriage was regarded as a purely civil contract, and in that form bitterly assailed by the Church fathers. Chastity was preached not because it was a good thing in itself, but because man's fall and the necessity for his redemption was traced to an indiscretion committed in the Garden of Eden. All intercourse between the sexes was discountenanced; to have children under any circumstances was a sin. Young people were enjoined to enter into vows of celibacy, and multitudes of them did so. Marriage was regarded as evil and vicious. Decrees were made forbidding married women to approach the altar or to touch the Eucharist, and it was even declared to be doubtful whether marricd persons cohabiting with each other 


\section{MORAL CONDITION OF THE CHILD}

We will not overlook those instances of the lustful movements of the flesh which are not restrained, and those sexual relations which are admittedly sinful. Of such improper relations there are two classes: (1) Those which are physically forbidden; (2) those which are morally forbidden. Social science is making a careful study of the first class and denouncing marriage or sexual relations between certain classes of people: those who are so physically diseased or defective that they can not transmit to their offspring sound minds or healthy bodies. The known law of heredity out of such violation of physical laws brings to children its fearful penalty of a debilitated or

could be saved. St. Chrysostom declared in the fifth century that if man had not sinned the world would have been peopled by other means. Any married woman who desired to be a nun was allowed to leave her husband, and he was forbidden to take another wife. Marriage was forbidden during Lent and at sundry other specified seasons, until, as an old writer quietly remarks, "There were but few weeks or days in the year in which people could get married at all." "In the fifth century priests were expected at least to abstain from the privileges of marriage, if not from marriage itsclf. Pope Innocent I. refused holy orders to any priest who had married a widow, and commanded every priest to be deposed who should be guilty of the crime of having children by his wife. It was not, however, until the twelfth century that the wives of the clergy were driven forth for good, and that the Roman Catholic priesthood was firmly established upon a celibate basis. - . Marriage was restrained, but not indulgence. Some of the popes led scandalous lives, and the clergy who did abstain from marriage kept concubines, sometimes in large numbers. - . Enactments had to be passed forbidding priests from living with their mothers and sisters, because of the prevalence of Incest; nunneries and monasteries were hotbeds of debauchery, and congregations who had an unmarricd priest to minister stipulated in some cases, with a view to the protection of their wives and daughters, that he should keep a concubine. In a similar spirit it was decreed by a council that no priest should be allowed to go out at night without a candle." (From Marriage and IIeredity, by J. F. Nisbet, 40-45, who refers as his authority to Lea's Sacerdotal Celibacy.)

It is not at all remarkable that from centuries of such abhorrent doctrine and more horrible practices that we should have as a heritage the doctrine of Original Sin. We only affirm that it is high time that our age which has clear moral vision concerning the practices, which are the root of this doctrine, should now turn away from the doctrine, which is its inevitable fruit. Humanity is disgraced by the doctrine as really as by the practices. 
degenerate nervous constitution. Children of such parents will probably be physically weak or idiotic or criminal. Thus physical heredity of physical consequences is freely admitted and greatly to be emphasized.

But it will be readily noted that this is not the inheritance which has given rise to the doctrine of Original Sin. We pass to a consideration of the second class: those who violate moral standards. Here we are dealing with fleshly lust and sinful gratification. The sinfulness, however, does not directly consist in the physical act, according to the general estimate of mankind; but in the violation of certain moral standards that society has erected governing the sexual relation. So that we have no reason to expect that the fruit of this sin will be shown in the physical nature or constitution of the child; but as a moral fault, if the law of heredity holds, it should be manifest in the moral constitution. Does the law of heredity manifest itself in the moral nature of illegitimate children? Are they more vicious, more morally perverse, more inaccessible to virtuous influence than other children? There are no known facts to establish the affirmative of this. In Roman Catholic countries of South America from fifty to ninety per cent of the children are born out of wedlock, or were previous to the enactment of recent civil marriage laws. These children can not be differentiated from others by any marks of vice or sinfulness. They start, so 
far as personal moral equipment is concerned, on a level with others. Nor can it be shown that the case is different in the far smaller percentage of illegitimate children in our own land.

When we consider the environment of these children and its legitimate moral effects, we will see that there is a real handicap in the race for life. The immoral conditions which produced the illegitimate relations persist after birth and through life. They can not fail to leave their impression. The child grows up deprived of the helpfulness of one or both parents. Even when the relations were not the outcome of unusual depravity of one or both parents, the lack of a proper family life is a great deprivation to the moral character of the child. Aside from this consideration we have no ground for affirming that the illegitimate child is more sinful in tendency than are other children.

But we return from this digression on the perennial elements of this subject to the primitive discussion which laid the foundation of the traditional doctrine. Coelestius, the disciple of $\mathrm{Pe}$ lagius, is credited with holding that " $\mathrm{sin}$ is not born with a man-it is subsequently committed by the man: for it is shown to be a fault, not of nature, but of the will." ("Nicene and PostNicene Fathers," V, 239.) In condemning this opinion and excommunicating Coelestius, the Church seemed committed to the materialistic view of sin, as something born in the flesh, and to 
have denounced the spiritual view that it is of the moral nature. Pelagius is quoted by Augustin as saying: "Everything good and everything evil on account of which we are either laudable or blameworthy, is not born with us but is done by us : for we are born not fully developed, but with a capacity for either conduct; and we are procreated as without virtue, so also without vice; and previous to the action of our own proper will, that alone is man which God has formed." (do. 241.) The other statement for which both of these men were condemned and which, it was assumed, was identical in import, is far from being so ; it was, "Adam's sin injured only himself, and not the human race." The word "injure" is too physical a term to cover the transmission of such a spiritual fact as the guilt of sin. Again, Augustin says ("Original Sin," 45): "A regenerate man does not regenerate, but generates sons according to the flesh; and thus he transmits to his posterity not the condition of the regenerated but only of the generated." This play upon words, without any pretense of estimating the realities behind the words, has held the Church in bondage to the doctrine of the unregenerated condition of children at birth for fourteen hundred years. It sounds like holy foolery that the practices of parents and Churches in child-training during all these centuries should be based upon word-plays without meaning. What possible meaning could the word regenerate have in ap- 
plication to a new-born child! The child is not even a person; it is only a non-moral being as yet. Augustin again says: "The real objection against them (the heretics) is that they refuse to confess that unbaptized infants are liable to the condemnation of the first man, and that original sin has been transmitted to them and requires to be purged by regeneration." It is not so very wonderful that such a physical disease, as $\sin$ is thus thought to be, could be cured by such a physical remedy as baptism in material water.

But sin and its cure can be applied only to a moral being. Moral qualities pertain to persons. An infant is not a person. Universal recognition of this fact is evident from reference to a child as it. Human law recognizes this, and the whole field of common sense affirms it. It does not even have a mind that functions, to say nothing of a conscience. It has not self-consciousness, much less moral consciousness. Theology has for long been an exception to the otherwise universal acknowledgment of this truth. At just what point we shall say the child attains to personality, it is difficult and somewhat arbitrary to say. That it is on the way to personality at five years, ten years, there will be general agreement, no doubt. That it has attained full personality before the close of adolescence would not be agreed to by all. That it has no moral character at birth, that it has full moral character at seventeen, are the two fixed points. That it is a partial moral being be- 
tween these points seems to be the necessary conclusion. Where the personality comes from is a question that the materialist can hardly answer. G. Stanley Hall says ("Adolescence," I, 2): "Certain it is that the cellular theory needs to be supplemented by assuming, both in the organism as a whole and in the species, powers that can not be derived from the cells." So if we should find that at one time the child is not a moral being, and later that he is, we would not need to be staggered by the fact, as it is no more contrary to the history of the individual than many a physical crisis through which he has passed. He has received from without that which was not within himself. We have to assume an outside Builder even of the body of the child.

To affirm sin of a being without personality or moral character is a confused use of the word, in which we must be thinking of some physical as distinguished from some moral conditions. The child-condition is a sort of larva-condition of personality. At puberty it throws off the old enclosure and passes definitely into a new state of personality for which the larva state was a preparation. The subordination of the child to the parent is based as much in its moral inabilities as in its physical. The parent is moral character for the child, and he has no distinct moral responsibility in himself, although he is constantly growing toward it through the years.

We must, then, avoid the confusion of moral 
and physical terms, and clearly apprehend sin as a quality of a moral being, and allow the appetites of the flesh to stand uncondemned as long as they perform their work of maintaining a normal physical basis for the spiritual life. We may have a diseased body, a riotous and uncontrollable nervous constitution, a deranged brain; but a sinful physical nature we can not have without robbing ourselves of words which describe the condition of a spiritual being, and leaving ourselves without any means of portraying the nature and working as well as the abnormalities of that being, so different from the physical.*

Without doubt the great weakness of traditional theology in its hold upon the people is the seeming unreality of some of its doctrines. The world's vital creed is wrought out in the experimental laboratory of life. The theologian's creed often smells of the cloister and the study. Some people will give assent to a fictitious creed that at the same time takes no hold upon their lives. They will still continue to repeat shibboleths into which they neglect to translate conviction. This is a triumph for formalism, but a loss for godliness. Moreover, those who balk are they who are

- "It had been a tendency of the Enlightenment to see in evil a mere defect of our sensual nature, which would disappear in proportion as reason became stronger. Kant, on the contrary, traces evil to the will: for him it is not a mere falling short of the good, but is in direct antagonism to it; it is not dependent on outward conditions, but is "radically" evil. The problem becomes thus more acute, but the philosopher is not thereby constituted a believer in the dogma of the Fall and Original Sin, that 'most unseemly of all conceptions.' For man has also a permanent disposition toward goodness, and this must be energetically called upon to confront the foe."-(Eucken: "Problem of Human Life," 640.) 
most earnest and honest and thoughtful. The skeptics produced by this unreality are likely to be those who are the real leaders of men; while those who slip through are likely to be the uncritical followers of others' thought.

That which does not appeal to us as real does not seem to us important. Hence doctrinal discussion fails to awaken popular interest. It is in vain that any effort is made to electrify doctrines into life which seem remote from the practical results of life. On the other hand, those discussions of great principles which appear to be close to actual destiny are listened to with great interest. If the preacher of to-day will go into the field of realities, discover the principles which are there working, and come forth and announce them to the people, he will have a hearing in any pulpit, unless perchance the pulpit itself refuses to give him admission to it.

Into some of the theology of our religious books fictitious elements have been introduced on one side to build a theory, and then another fiction is introduced to cancel it, so that the result may be somewhere near what the universal sense of mankind demands. For an example, in Pope's work on "Christian Theology" (III, 317) we find him saying: "Children of wrath as belonging to the lineage of the first Adam, they are grafted into the second. . . Unholy by nature, they are sanctified through baptismal consecration to God." This is evidently dealing with imaginary 
transactions; there is nothing real about it on either side. The process of salvation is made a sort of arithmetical problem, worked out by some second person, without ever touching the actual personality of the person who is saved. John Jones from the hand of God was a child of God; but something happened with which he never had anything to do, which subtracted something from his acceptable relation to God. But this seems rather hard; so something on the other side was done, with which also he had nothing to do, which restored him to his original relation of acceptability.* This is a fiction, as needless as it is irrational. There is no warrant for saying that God really is, or ever was, angry with children before they had ever done wrong. The conception is revoltingly repudiated as dishonoring to God by the unbiased judgment of enlightened mankind. The author himself very well knows this, and hence he invents another fiction to right himself in practical results. (I will not insist

"Luther in his commentary on Galatians says: "And tbis (no doubt) all the propbets did foresee in spirit, that Cbrist sbould become the greatest transgressor, murdercr, adulterer, thief, rcbel, and blasphemer tbat ever was or could be in all tbe world. For He being made a sacrifice for the sins of the world, is not now an innocent person and witbout sins, He is not now tbe Son of God born of the Virgin Mary, but a sinner, whicb batb and carrietb tbe sin of Paul, who was a blaspbemer, an oppressor, and a persecutor; of Peter, which denied Cbrist; of David, which was an adulterer, a murderer, and caused the Gentiles to blaspheme tbe name of the Lord; and briefly, whicb batb and beareth the sins of all men in His body; not tbat He Himself committetb them, but for that $\mathrm{He}$ received tbem being committed or done of us, and laid tbem upon His own body that He migbt make satisfaction for tbem witb His blood. . . . Our most merciful Father - - sent His only Son into the world, and laid upon Him all tbe sins of all men, saying, Be Thou Peter that denier; Paul tbat persecutor, blaspbemer, and cruel oppressor; David that adulterer; that sinner tbat did eat tbe apple in Paradise; that tbief whicb banged upon tbe cross; and briefly, be Tbou the person whicb hath committed the sins of all men."-(Quoted by W. Hale Wbite: "Bunyan," 98, 99.) 
that it was his personal invention-for it is hoary with age; his responsibility may only be that he did not reject it.) It is as profound a fiction as was ever conceived to affirm that water baptism has anything whatever to do with the moral nature of a child. It is simply not true. No evidence for it from life can be produced. No rational necessity for it can be shown. I will not undertake to prove this negative position. Like any other axiomatic position, it is impossible to make its offensiveness to truth and justice any clearer to him that does not see it. But one inference from the position it is worth our while to arraign. If baptism is necessary to arrange children's relation with God, then those children whose parents are too negligent to attend to their baptism remain under the wrath of God." This horrible conclusion might have gained a standing in the darkest Middle Ages, and may still occasionally be heard among those who have not moved entirely out of the twilight; but it is so nearly extinct, and its death-gasps are so nearly inaudible that there is no motive in striking it another blow, unless to quickly end its dying misery. We are so far away from it in our thought that we are startled when we see the evidence that it once lived on this side of the Atlantic. But there is material evidence of it in Copp's Hill Graveyard in Boston, where there is a mound raised over the place where the fathers buried the little bodies of their unbaptized chil- 
dren. The superstition was so cruel that they believed that the very dust of their loved babies was so vile with original sin that it could not share the consecrated places where other dust, that had had a little water ceremonially sprinkled upon it, rested! I here record the revolt of my nature against this misuse of children's baptism. In another place I shall give reason for my unqualified approval of its rational and useful observance. (See Chap. XI.)

\section{Original Sin and the Virgin Birth.}

It has been thought possible that the story of the virgin birth of Jesus has had some relation to the assumed sinfulness of the act of human procreation. On the affirmatory side of that conclusion are the following considerations:

1. Those who accept that account would explain some of the silences of some current narratives by the supposition that it was a subject that would not be talked about until after Jesus was worshiped. One writer (Garvie: "Inner Life of Jesus," p. 90) thinks that it may have been "only after the death of the mother of Jesus" hence long after the death of Jesus Himself-that it came to be more openly spoken about. Concerning this it should be noted: unless it was known and used to establish the Deity of Jesus, the record of it was needless. If it came to be spoken of only after Jesus was regarded the Son of God, it is difficult to see why the account was 


\section{ORIGINS}

not altogether superfluous, in the thought of any other age than one that regarded natural procreation as sinful.

There were two persons to whom, if for any one, the knowledge of the supernatural conception was important, viz., Mary and Jesus. Yet those who seem to think it an important link in the establishment of Christ's Deity, think it was not an appropriate subject to be communicated to Jesus even when He was twelve years of age and had arrived at some degree of divine consciousness. They seem prone to put off the necessity of that information until Jesus had come to the Messianic consciousness by the direct operation or suggestion of the Spirit. But one is bound to ask, If not used to communicate and establish that consciousness; if that consciousness is possible by other means, of what value is the communication then? Is it needed to confirm the other communication, as if that in itself were doubtful? We feel much like insisting that the communication of the Holy Spirit to the consciousness of Jesus was so immeasurably more sure than any assurance coming through human channels concerning an event long past could possibly be, that the latter is not to be mentioned as a ground of assurance of His divine nature for Him.

Further, the importance of the knowledge of this event to Mary rests on the part that she would have in establishing by testimony to it the 
divinity of her Son. If now we suppose that she never so used it, and that it was used only after her death, we have destroyed its value for her, and hence for others.

If the value of the account to these two is thus eliminated, there remains no value in it except to the apologist, and for him it rests upon the false assumption, as we contend, of the doctrine of hereditary sin in normal human nature. If Mary is not the witness that established the fact, it clearly is in the region of speculation, the motive of which is to relieve Jesus of the taint of original sin.

2. From a biological point of view this story is of trivial importance in any age which knows the process of the origin of a physical human life. It is a physical fact that is to be accounted for in any possible supposition, and the alleged virginal conception in any case can account only for an animal life which is to be used by a spiritual being. That God should use one physical agency rather than another has no significance whatever as to the nature of the spiritual being, who shall instrumentally use the animal nature thus pro'duced.

Concerning the ascetic tendency which may have been a factor in the origin of the story, Garvie (op. cit. 93) says: "The ascetic tendency to depreciate marriage and to exalt celibacy did undoubtedly find encouragement in the belief in the virginity of the mother of Jesus. But this 
ascetic tendency appeared in the Christian Church at a later period than the narratives of the birth of Jesus. If it had had any connection with the origin of these narratives it would have been at pains so to tell the story as to put Mary's perpetual virginity beyond doubt or question, whereas the impression conveyed in the Gospels is that after the birth of Jesus, Mary lived with Joseph in wedlock. It is now generally agreed that the stories of the infancy are of undoubtedly Jewish origin, and in Judaism marriage was not depreciated, but regarded as honorable."

It is evident from the reasoning of certain authors that this matter of the virgin birth has something to do with the sinlessness of Jesus. It may be that that is its real if not entire significance in their minds. To quote again from Garvie, who may stand for many others who thus reason. He says (op. cit. 98) : "It is also certain that there is no other human personality, except Jesus, in which a hereditary tendency to sin and distrust has not appeared. It is a fact beyond question that all children are born members of a sinful race, and have been tainted from their source (italics ours). A sinless and godly development appears impossible for all who are completely, by natural generation, incorporated in the human race. . . . While it would be rash and bold-dogmatism to affirm that, had Jesus been born naturally, He must have displayed the inherited defects of the race, as we can conjecture 
that divine grace might have acted prior to thought and will so as to suppress all hostile elements to a perfect moral and religious development; yet as a supernatural mode of birth is ascribed to Him in records, the witness of which to His words and works secures our credit and commands our respect, it is not a vain imagination, but a good reason to connect these characteristics of His personality with this unique feature of His birth." The drift of the thought of this writer is easily seen: Jesus was sinless, because He was procreated in a unique way. But it remains to ask, Did Mary transmit to Jesus real human nature? If not, what is to be our estimate of the Incarnation fact? If she did, what has this unique birth to do with the fact of His sinlessness, if we assume, as does this author above, that all real human beings are sinful? Would it not be more to the point if we should account for His sinlessness from the birth of His spirit? (Our own view of the distinction of the birth of the spirit from that of the body is set forth in a later chapter, Vid. chapter III. It is only necessary here to suggest that it is not identical with the fleshly birth.) Garvie makes a strong reply to himself when he says: "It seems to the writer unfortunate that the term virgin birth throws so great emphasis on the absence of the paternal function, as though the maternal function under normal conditions were not as liable to be the channel of hereditary taint, or as 
though it were the union of two functions, that caused the transmission of evil."' (Op. cit. 99.) How inconsistent are they who admit that Joseph was competent to be the instructor and governor of the child Jesus, but not to be His physical father, and yet allow that to be the spiritual father of a child is a much higher function than that of being his physical father! We believe that we are marching rapidly toward that day when the spiritual will take a primary place in life and be emancipated from the hitherto dominance of the physical.

A further examination of this particular author, and possibly of others who draw similar conclusions, would show that he entirely mistakes the part which heredity plays, as when, for example, he speaks of Jesus inheriting from His mother "faith in, and surrender to, God." We shall show later on that moral and spiritual, individual as distinguished from race, qualities are not transmissible by heredity. (Vid. chapter VII.) Nor is he scientifically justified when he says (p. 105): "The pre-natal influence of the mother on the child was a channel of grace, confirming the tendency of faith."

Finally, the question may be considered to have bearings in three directions: (1). The integrity of the manuscripts. That is a question for the lower or textual critics to decide. (2) The influence of the doctrine of hereditary sin in the origin of the account in the Gospels. That ques- 
tion the higher critics may decide. (3) The theological bearing of the account. That is simply nothing. The theologian may look on in serene indifference while the question is being settled by the two sets of scholars mentioned, knowing that the doctrine of the Sonship of Jesus is not involved in the least degree. As already stated, it may not always have been a matter of indifference to the theologian. There may have been a time when everything from his point of view seemed to hang from it. But to emphasize this fact is only playing into the hands of the higher critic, who may claim, if the case is made strong enough, that the story is accounted for by that fact. It may still be a matter of weight, although involved in much difficulty, to the theologian who has inherited a scientific doctrine, now quite generally repudiated, that a spiritual or moral quality is a subject of heredity. It may still seem important to those who pin their faith to the marvelous and the extraordinary; but to him that believes that all processes of nature, common and extraordinary alike, are equally manifestations of the divine, and may be used by God as the instrument of His plans, it can not matter how this controversy is settled. His faith can be adjusted with equal ease to either solution, not because he has a spirit of indifference; but rather because he has the vision of God as filling all in all. Our contention is not an effort to eliminate the virgin birth as a part of the creed; we have no interest 
in that. But we do find it necessary to divorce from that belief the assumption that the sinlessness of Jesus depends upon it. For such a conclusion it is an entirely illogical premise and is utterly inadequate. From the point of view of transmissible hereditary sin, if Mary is the sole human parent of Jesus, for such a sequence she must be removed from the class of the sinful. Roman Catholic theologians were entirely logical in seeing the necessity of the doctrine of the Immaculate Conception of Mary, and then of her mother Anna, and all down the line of her ancestry, if they would be thorough. If the doctrine of Original sin makes the virgin birth a necessity to faith, there will be exactly the same necessity for the doctrine of the Immaculate Conception of Mary and her ancestry. 


\section{CHAPTER II}

THE CHILD AS A FACT GIVEN BY NATURE

WITH the above criticism of the traditional theological doctrine, we prefer now to turn away from this method of investigation to the true scientific method of recording what we actually see in the child as a fact of nature.

We will avoid the exegetical method for several reasons: 1 . It would involve an estimate of the point of view of Biblical writers, after the methods of the Higher Criticism; e. g., What must be said of Psalm 51:5, "Behold, I was brought forth in iniquity; and in sin did my mother conceive me?" Is it scientific prose; or poetic emotion? Is it a doctrinal enunciation; or the outburst of a penitent heart concerning an individual experience? We fancy that the outcome of such an examination would be somewhat affected by the personal equation.

2. The history of exegesis has shown that previous views have the deciding influence in exegetical balances, where Scripture passages, seemingly in opposition, can be quoted on both sides. So from the Biblical side I satisfy myself with re- 
calling the words of Jesus, "Of such is the Kingdom of heaven," as equally weighty with anything that can be quoted against them, and pass to what I believe a more decisive method of investigation.* Until the data and methods of exegesis are more correctly defined it will hardly be a sufficient method of settling even theological questions. The age-long controversy concerning the method of baptism, which bade fair to be eternal on the battlefield of exegesis, received its quietus when "The Teaching of the Twelve Apostles" was discovered or recovered from its long hiding. An ounce of fact is worth a ton of argument.

- We may anticipate the probability that those who regard us in error in rejecting the doctrine of Original Sin will bring forward some of the passages of Scripture that have been used to perpetuate that doctrine. Our limits do not pcrmit us to take up those passages in detail and show them harmonious with our position. We can only say that we feel that our Scriptural authority is sufficient in building on this saying of Jesus - "of such is the Kingdom of heaven." No possible interpretation of these words can leave standing the doctrine that children are sinful when born. If now some one is able to show that other passages of Scripturc are incompatible with it, while not interested in making Scripture thus contradict itself, we are not moved from our standpoint by it. In case of a contradiction bet ween Jes us and someother or many other Scripture writers, we stand by the word of Jesus as invincible authority. In case of an apparent contradiction, as by the words of David-"in sin did my mother conceive me"-we would seek if possible some explanation that would not make out such a direct contradiction between Jesus and David, such as: this passage is an expression of extreme emotion and not intended as a statement of universal application; it is a poetical statement, and must not be interpreted as prose, etc. Our motive would be to relieve Scripture of contradiction, and it would never occur to us that even sevcral such passages would make it neccssary to conclude that Jesues was mistaken in a statement so very simple, whose meaning is incontrovertible, and whose interpretation can not be twisted in support of the doctrine which we renounce. In other words, a clear word of Jesus is of such preeminent authority that it can not be overthrown by any number of other writers, even writers in the Scriptures themselves, Furthermore, if we have found an unmistakable teaching of Jesus, why must we seek further light in an age admittedly dark? For purposes of corroboration, it is needless; for purposes of refutation, it is futile; it could only be useful when the word of Jesus was of uneertain meaning. 


\section{MORAL CONDITION OF THE CHILD}

What Does the Book of Life Tell Us of a Child at the Time of Its Entrance Into the World?

That book presents us with an animal, indistinguishable up to this point from the other animals that inhabit the earth. I now quote at large from Prof. Edward Porter St. John, who is an authority good enough in science and religion to have his findings in the Sunday School Journal.

"Every human being begins his existence in the form of a one-celled germ, which is anatomically and biologically very like the lowest forms of animal life that are known. Later the embryo takes on a wormlike character. This is followed at about the third week of development by what embryologists universally call the fish stage. The body is elongated, there are four finlike limbs, the lungs appear only as a bladder-like rudiment, and the neck is furnished with gill slits. There are other resemblances in the shape of the brain and face.

"At about the beginning of the third month the gills have disappeared, the lungs have developed, and the limbs have taken on marked characteristics of reptilian life. At the fourth month the spine has the double curve of the lower vertebrates. In the sixth month the whole body, except the palms of the hands and the soles of the feet and a few other small spots, is covered with a fine, dark hair, known as the lanugo. The direction of 
the growth of this hair on various parts of the body is precisely like that on the corresponding parts of the bodies of apes and monkeys; for example, from the shoulder to the elbow the hair points down, from the wrist to the elbow the direction is reversed. This hair usually falls off before birth, though occasionally it persists on the scalp for some time, to be replaced later by the growth that is characteristic of men.

"At about this time the hands and the feet of the fetus are practically alike, the great toe being shorter than the others and projecting at an angle, as in the case of apes. Through several of the stages the fetus has a clearly defined tail, and at one period it is longer than the legs, as in some of the highest mammals. Throughout these various stages of prenatal development the brain and the nervous system show very close likeness to those of the animals of the corresponding levels.

"Even at birth the body of the child in some particulars resembles that of the ape more than that of the adult man. . . . In some of the early instincts the likeness between the child and the lower animals is quite marked. Especially remarkable is the fact that for a few weeks, beginning a few hours after birth, the child will support its entire weight for periods lasting from a few seconds to nearly two minutes by clinging with the hands to a cane or similar object. The power to do this is soon lost, and does not re- 
appear until a much later period."

(Sunday School Journal, 1910.)

I have made this extended quotation to show that this child is so evidently related to other animals thus far in its history that we are justified in calling it an animal, unless there are other revelations that make it transcend the animal kingdom. Are there sucl evidences?

It is perhaps quite difficult now for us to confine our attention to just what we see. We have seen other infants grow up to show reason, intelligence, conscience, imagination, and other marks of personality and moral character. It is almost inevitable that we think this being has all of these qualities, but for the present that it does not know how to express them, or that they are in a sort of undeveloped state, or-something; we may have never explained to ourselves just what. We spontaneously think he is a person; he has thoughts, if we only knew how to get at them. But this is allowing imagination, and not observation, to form our convictions. The child is what we see; we have no good right to read into him what we have seen developed into other children that had the same kind of beginning. It would require much marshaling of technical authorities to prove this in detail. I do not feel called upon to prove a negative, but simply to call attention to what the living child testifies. This little being has no morals; he has not even thoughts; he can not see objects or discern colors; he has not 
even perception, much less conceptions or ideas. "Infancy is mental vacuity. Human life makes its appearance wholly destitute of intellectual content. And not only is there the absence of knowledge, but also of the power of knowing. Mind potentially is a substantial foundation of powers and ideas, but at first there are neither ideas nor powers." (L. R. Fiske: "Man Building," 251-2.)

If the above can be said of the mental powers of the child, much more may it be said of the moral powers. Infancy is moral vacuity. Human life makes its appearance wholly destitute of moral content. The conscience, or moral nature of a child, is a vessel, indeed; but it is absolutely empty at birth of moral ideas and of moral character, either in the form of merit or demerit. The view of De Pressense is as follows: "Man begins with purely instinctive life, without any clear consciousness of itself. In this phase the individuality, the ego, the person, exists only in germ, and is not separable from indistinct impressions of which it is vaguely the subject. This instinctive life makes man in the first stage of his existence closely akin to the animal, though there are already indications of the essential difference which will ultimately appear between them. . . . It is governed by the sensations, affected and modified by them, and apparently submerged, like the swimmer who can not lift his head above the rapid stream that is carrying him along. He does not truly know, because he does 
not clearly distinguish himself from the object affecting him. Instinctive knowledge is then only sensation more or less confused. The will, at this stage, is nothing but an impulse urging on to a blind movement, under the influence of the instinctive feeling which makes man seek the pleasant and avoid the painful." ("A Study of Origins," 251, 252.) He sums up the activities of the soul in the three faculties: to know, to love, to will. The infant has none of these faculties in exercise. He is classified as a human being, not because of the manifestation of either of these or of any other faculty distinctly human, but solely because of his birth from human parents and the known development of other beings like him. The infant has few instincts, and these incomplete, but he has an enormous capacity to learn.

"The baby new to earth and sky,

What time his tender palm is prest

Against the circle of the breast,

Has never thought that 'this is I.'

But as he grows he gathers much, And learns the use of 'I' and 'me,'

And finds ' $I$ am not what I see,

And othar than the things I touch.'

So rounds he to a separate mind

From whence clear memory may begin,

As thro' the frame that binds him in

His isolation grows defined."

-Tennyson: In Memoriam. XLV. 


\section{What, Then, Is This New-born Baby?}

He is not a moral being. He is not even an intellectual being. If we say he is an animal, what is implied in that statement? It would be quite beside our present purpose to describe his muscular and anatomical construction. But it is not so far from our purpose to say that he is a nervous organization. All his present reactions from the outside world are nervous. The first nervous response from his new habitat is a gasp and a cry that establishes his new respiratory method of life. Now and increasingly in the days just ahead of him there are various actions of which he is capable, but they are all nervous responses to outward stimuli, plus certain inherited reflexes, which are generally known as instinctive tendencies. He does nothing as the result of thought. He does nothing as the result of willing, and consequently he does nothing as the product of a malicious will or an evil disposition. Nevertheless we will hear longheaded observers pointing out soon the evidences of his fallen nature. They will observe that he is mad. They will soon see that he is stubborn, etc. And they can point out numerous indications very soon that he is acting in the way he does in consequence of the sin of Adam.

Before we leave the child under this Adamic condemnation, let us observe a kitten. How many days after its birth will it be before it spits at 
you when you act upon it in a way that it does not like. Can it not show a pretty good case of cat-stubbornness and strike-back-a-tive-ness, while the child as yet is quite innocent of such action? Is it sin in the kitten? Is it the evil nature within it resulting from the transgression of some primitive Adamic cat? If this is absurd, why on similar evidence do we condemn the child? Before the dawn of reason and of the moral sense, is there anything culpable in a being that is nothing more than a nervous machine acting in a manner that tends to self-preservation? At this stage, is not self-defensive reaction the only virtue it can display? For the time divine wisdom can do nothing more for it.

I am sure that I shall be more than pardoned for introducing the following words, so illuminative of this point, from Prof. Edward Porter St. John. He says: "In the early selfishness, which later gives way to altruism, we gain another glimpse of nature's way of working. . . . One must get before he can give, and so she bends her energies at first of all to the building up of a strong personality, which shall be able to serve another generation. There are certain large moths in which the caterpillar stage lasts for weeks or months, during which time the insect lives to eat; in the adult stage, when they have acquired wings, they take no food at all, and live simply to prepare for the next generation. Here is nature's parable of the spiritual life. Here is 
the biological explanation of the unselfishness of parents-and of the selfishness of children as well.

"But in the egoism of the child we can see more than this of nature's plans; for she is never inconsistent with herself, and the development of morality is one of her chief concerns. Not only is it true that morality does not suffer from the natural selfishness of the child, but it is really dependent upon it. In the development of almost every one of its elements we can trace an egoistic or selfish stage. The child feels resentment for a wrong done to himself. If it were not so, how could he ever feel indignation for a wrong done to another? The boy is not content with simply exhibiting his own attainments; he must outdo another. The self-feeling which now finds expression in rivalry, will, by and by, manifest itself in the positive form of self-respect and the negative form of humility, which seem more admirable traits. But how can he ever feel humility unless he measures himself by another? And how can he so well gain his standards of self-respect as by comparing himself with one who has reached the higher level? Until a child has built up a feeling of ownership in property that is his own, how can he learn to sympathetically regard the property rights of another? Surely God has not blundered in shaping the soul of a child.' (Sunday School Journal, 1910, p. 487.)

The fact is that many things are charged against the child sheerly because he can not de- 
fend himself against the slander, and has to receive, under adult promises of punishment if he should talk back, many unpleasant conclusions. A little girl one day in tears said to her mother, "When you do that, it 's nervous; when I do it, it 's naughty.' In fact, this is just the reverse of the truth. An adult with a developed conscience and power of self-control can not do certain things without moral condemnation, which a child might do as the reaction of a nervous organization against an unpleasant stimulus, without feeling any sense of wrong. This little nervous organism, a full-blooded member of the animal kingdom, and only a candidate for the human kingdom, can not commit a sinful act until there is within him, given by some process profoundly mysterious, a standard of righteousness and apprehension of a Person whose rights are violated by the action. As yet there is not in the child the first gleam of such a standard, nor the remotest possibility of perceiving such a Person. How meaningless, then, to speak of his sinfulness, when he has not the most incipient power of sin!

How can they be essentially sinful in origin of whom one can so beautifully and truthfully say: "The breath of God breathes in them and through them upon our concerns. Motherhood dawns when they appear, and the inexpressible sanctity and tenderness and charm that wait upon their arrival are the cardinal blessings of life in its diviner aspects. Let nothing rob us of this 
humanness which proceeds from the Everlasting Father; permit nothing to make us forget that every life born of a woman is a visible expression. of the life of God. Whatever in our race is uplifting and most worthy, its strength, its perennial honor, its divine likeness and growth, depend alike on childhood." (Dr. S. P. Cadman in Brooklyn Eagle.)

But one replies, "The child has a sinful nature."

This word "nature" is made to do large work in the world. Upon its very vague and indefinite corporosity are piled many a burden of logic, theology, and philosophy. What do people mean by a sinful nature or fallen nature, which latter term is used to convey the same meaning? Is a sinful nature a nature that sins? No; it can not be that: for we have seen that the infant can not sin. Well, then, it may be said that a sinful nature is one that will develop into a nature that will sin. This puts sinfulness back in the order of nature where there is no volition, no moral choosing; back into the causal order of things where there are no alternatives; back in the iron grip of powers that ean not be other than they are, and for which no one but God, who made them so, is responsible. If there is one heresy in the world more heretical than another, it is the heresy that makes God the author of sin. Moreover, there is absolutely no logical necessity for this assumption of the sinfulness of human 
nature, as it comes from the hand of God. The well-known and easily observable facts concerning the child furnish all the conditions for all the actualizations of its after-life.

The infant is an animal. It is not sinful for an infant to be an animal and to act as an animal. But it is sinful for an infant forever to remain an animal, and after reason and conscience have arrived to act as an animal. This child is an organization of physical nerves to-day; but tomorrow, by some process, mysterious under any theory of his life, he will be a rational, a moral human spirit, without losing one of his appetites or fleshly passions or nervous impulses. To-day he can not act differently from what he does act, under any possibility within his control; but tomorrow he may go to the right or to the left, up or down, in any direction in which his animalism impels him, or in the direction in which his higher spiritual nature draws. The animalism of his condition accounts for all the facts of action and tendency, impulse and spiritual struggle that the assumed sinful nature accounted for. The animal nature, which is undisputed, provides the field of moral and spiritual conflict that will last as long as life lasts. In this struggle there is no sin implied, but a condition which may issue in sin at any moment that the person may so decide; but which will never so issue of necessity, never unless and until he so decides. To overcome the animal, subdue the animal, rise triumphant above 
the animal, is life's problem of personal character.

In the struggle with animalism, as in the traditional struggle with inbred sin, there is no personal deliverance and victory except through God's aid, which is graciously offered to all, and by it sinning is destroyed as a necessity.

It is not the problem of spiritual life to kill this animal, which God gave us at birth. It was God's first gift, and unmistakably represents His goodness and wisdom. But it was never given us as representing man's final condition; rather it is only the starting-point of life. As such it has nothing but an impelling force. It can not see the way for a man; it can not appreciate the worth of a man; it can not choose the way or the destiny of a man. It, then, needs control, limitation, denial, guidance. The moral problem of life, as related to the animal nature, is contained in these actions of mastery by the rational nature.* We are never to attempt to destroy any animal impulse, much less to claim that by the power of God's grace any animal impulse has been destroyed. These impulses are not sinfül. Life under grace tends to their strength and health rather than to their weakness and nega-

* "Men, it is true, no longer believe in the devil's agency; at least, they no longer believe in the power of calling up the devil and transacting business with him; otherwise there would be hundreds of such stories as that of Faust. But the spirit which created the story and rendered it credible to all Europe remains unchanged. . . . We do not make compacts, but we throw away our lives; we have no tempter face to face with us, offering illimitable powers in exchange for our futurity; but we have our own desires, impcrious, insiduous, and for them we barter our existence - for one moment's pleasure risking years of anguish."-(Lewes: "Life of Goetbe," II, 270.) 
tion. Their destruction is not sanctification, as many suppose; but is rather the retributive effect of their unrestrained abuse. They are to be used and mastered in the interest of the rational life, under the over-guidance of divine law and purpose, by the assistance of the Divine Spirit.

It is an ordinary assumption that sin inheres in the flesh. Writers who treat of the nature of Jesus argue that it was necessary for His personality to have a fleshly nature in which there is no taint. Says one writer: "How much more, then, in the nature of things, is it necessary that He who came to redeem men from sin should Himself be without sin in His own flesh! An immaculate spirit demands an immaculate organism." (Cooke: "Incarnation and Recent Criticism," 147.) What can this mean? It is hard to answer, unless we assume that the absence of sin in the flesh will be evidenced by the absence of fleshly appetite, passion, impulse. But such an absence is not purity, it is mutilation, destruction of the bodily function in one form or another. It is something that has no analogy or suggestion in the experience of Christians. The Christian who attains the highest degree and experience of purity does not thereby lose any animal appetite or passion; he receives only such a spiritual endowment that he is able completely to control them. This control is the vital and sufficient thing in a member of our race. Not absence of conflict, but victory, is human excellence. This demand 
for the elimination of passion and appetite, usually prejudgéd by being called "sinful appetites and passions," arises probably from the assumption that animal appetites and passions are in themselves sinful. But this throws the burden of sinfulness back on to God, who alone is responsible for human nature in this form, and who in the beginning pronounced them good.

A little reflection will bring the conviction that sin is a moral thing; a something where choice is involved; something which pertains to the will and the spirit; something which is not grounded in a nature; not an unavoidable, normal impulse; not a thing for the elminiation of which no provision is made by grace through faith in Jesus. Sin has a moral remedy; but appetite and passion have none except drugs and the surgeon's knife.

Have we, then, merely substituted one term for another-the term animalism for sin? Is this all a discussion about words? I think that can hardly be said. The whole conception has been changed. The traditional view had a sin on its hand for which there was no rational cause, either human or divine. The human causation, Adam's primeval sin, always involved injustice, confusion of moral conceptions, and an irrational philosophy. It has long been rejected by scientific minds. The assumed divine causation reflected on the goodness and equity of God, and should be given up in the interest of divine honor, even if we 
are left without any means of accounting for the moral history of the individual. Our explanation, on the other hand, throws back no great burden of responsibility on the first man; allows the wisdom, the goodness, and the justice of God to stand unchallenged, and at the same time affords every datum of explanation of the subsequent history of the child that the traditional view possessed. And it does much more : it allows us to use physical descriptions of physical conditions, and reserves to us the word "sin" for application to a fact purely moral and spiritual. It gives us a rational and possible basis for a life of struggle, which no man ever could avoid, whatever his professions and claims, which life God can smile upon and reward. It gives an explicable view of the sanctified life, which, under the supposition that animal propensity was sin, was made impossible and absurd. These are not small contributions to an explanation of our spiritual life and its reconciliation with our actual life in the body. Moreover, it creates no difficulties to offset its gains, unless it be the straightening out of some exegesis based on the materialistic view of sin. Having meditated much upon it, I know of no Scripture that may not be explained in an atmosphere of candor, although there are several that may be quoted in a controversial spirit. 


\section{CHAPTER III}

THE BIRTH OF THE SPIRIT

Has the child a soul? Lotze places the proof of a soul in the possession of a unity of consciousness. The test seems to be that a being having a soul (or a rational spirit) is one that recognizes itself as one being, or the experiences which it has as belonging to its one self. It is doubtful if the child can stand this test. His reactions against the external world are purely nervous. The nerves feel pain, but the child is not conscious of a pained self. His hands and feet are as external to his consciousness as any other objects he may see. To say that he has a potential soul, a something that will come to unity of consciousness soon, may be true enough. It is immaterial to our discussion, and its investigation would lead us far afield. It is enough to notice that such a soul is of no value to his present constitution of moral character.

That the new-born child has an animal soul, a forming principle which builds his body and animates it, is beyond question. As much possibly can be said for the cell which was its starting-point of being. But that he has not a ra- 
tional mind, rendering him capable of moral action, is almost as indisputable as that the cell had not. The relation between these two, the cell and the rational nature, constitutes one of the most interesting and intricate problems of human life. Whether the Bible holds to a tripartite or dual nature for man is, I believe, an unsolved puzzle. According to Franz Delitsch, in his great work, "Biblical Psychology," (103), the Scriptures make a sharp distinction between flesh and spirit, and yet the flesh is endowed with soul. This soul of flesh the child has; but there is as. yet no exhibition of the spirit. When is this higher spirit born?

Evolutionary philosophy can not furnish us an answer. There are two things for which Evolution has no explanation, nor can it give us the slightest hint concerning their origin. They are: the origin of life and the origin of spirit. Many attempts have been made to deduce life from matter; but they have always been unsuccessful, and for the time being, at least, they are now definitely abandoned. Just as little can Evolution account for the introduction of spirit. This task, then, we may place beyond human power to perform. We can not, apart from revelation, give any account of the origin of the human spirit. Its existence we accept as a fact; the evidences of it are abundant; but whence and how it came to be we have nothing to say, except that the Bible says we are sons of God. If Traducianism be true, that 


\section{THE BIRTH OF THE SPIRIT}

the spirit of the child is derived from the spirits of the parents, we might assume that it originated at conception; though the assumption would not be compelled and in itself is very difficult. If the origin of the spirit is subsequent to conception and previous to birth, it then seems a necessity of belief that the child's spirit is derived from its mother, but not from its father. The difficulties that gather about Traducianism seem to make it an almost impossible belief. On the other hand, if we accept the doctrine of Creationism, that each human spirit is a direct creation of the Divine Spirit, the time of its origin may fall within a wide range.

When the spirit is born, is about as easy to answer as where it is located, a question which has been one of the puzzles of philosophers, little and big, of all ages. If I am not mistaken, Joseph Cook lectured on this subject in his Boston course more than thirty years ago. But I do not remember that he solved the mystery.

The pre-existence of the spirit as pictured by Wordsworth in the following lines, is a beautiful poetic conception; but hardly needs serious discussion. Its truth or untruth is outside the limits of our investigation.

"Our birth is but a sleep and a forgetting:

The soul that rises with us, our life's star, Hath had elsewhere its setting, And cometh from afar;

Not in entire forgetfulness, And not in utter nakedness, 
But trailing clouds of glory do we come From God, who is our home:

Heaven lies about us in our infancy; Shades of the prison house begin to close

Upon the growing boy,

But he beholds the light and whence it flows:

He sees it in his joy;

The youth whom daily farther from the east

Must travel, still is Nature's Priest,

And by the vision splendid

Is on his way attended;

At length the man perceives it die away;

And fade into the light of common day."

(Wordsworth: "Ode to Immortality," V.)

The uncritical, no doubt, assume that a child is born with a rational spirit and may lift their eyebrows in astonishment that such a position could ever be questioned. But such persons would be at their wits' end if they should be asked when the spirit became identified with the child's body. Was it when it was a single cell? Was it when it was in the fish stage? or in the reptilian stage? or the simian stage? Did it come to it at its first gasp for breath? Did its first ery become the anguish of a human spirit? I fancy that it would be rather difficult to reply affirmatively to any of these questions, and I, at least, will not have the temerity to reply negatively. If we reason from the analogy of the origin of the body, and suppose that the spirit is not the product of any one moment of time, and that only its germinal potentiality is given in birth, and that this potentiality in no wise functions as it does in its complete manifestation, we may best account for all 
the facts. The ground for assuming this potential beginning is admittedly a priori. We can not observe in the child any more evidences of spirit than we can in the kitten; but we believe it belongs to the genus homo, and if not an idiot, has powers which will unfold into spirit-action after awhile, and respond to environment as the kitten never will.

Of one thing, however, there can hardly be a dispute: at birth the human spirit, if existent at all, has not come to its manifestation. So our inquiry may take the form: when does it come to manifestation, so as to be clothed with moral freedom and human responsibility? For myself there are no more rational difficulties in assuming that the spirit is coming to its birth than there are in assuming that it is coming to its manifestation and responsibility. But our purpose is equally served with the question in either form.

A child may profitably be contemplated as two selves: his realized self; what he can do. This depends upon his past; what he has learned to do. Second, his potential self; what he can learn to do and may become. This latter depends upon the contribution of others. His potential self is not yet born or actualized. If at birth thrown upon his own resources, what he can do is quite insignificant. He will never be able to talk, and without speech his thought will always be infantile and meager. One writer has said that he can never be a person unless he mingles with 


\section{MORAL CONDITION OF THE CHILD}

persons. It is certain that he will be so circumscribed in power, he will be so unlike other persons that we know as such, that the remark is practically true. A new-born babe, henceforth cared for by some kind animal, such as the fabled wolf which suckled Romulus and Remus, and never coming in contact with human kind, would be such a defective human being, and so much like the animals with which he grew up, that there would be no suggestion of personality except the form of his body. So the real self is the second self, which is yet to become after his physical birth, and the contribution to his being is chiefly through the mother and father who watch over him. They are giving birth to him all through the years of his developing selfhood.

In assuming the possibility of a germinal origin of the spirit apart from the germinal origin of the body, we recognize that we are quite beyond the boundary of the known. However, the supposition will be justified if by it we can rationalize, even in a small degree, this very mysterious realm. The objections to it seem to be born chiefly from materialism, and make the doctrine of immortality impossible. In our speculation we are doing much the same as we do after the death of the body. It is about as much outside the realm of the known to imagine the spirit as existing after the physical dissolution of the body as it is to imagine the physical organism before birth as not yet inhabited with a spirit. It 
is quite as rational to assume that the spirit is a separate direct creation of God as it is to believe that the spirit "returns to God who gave it" after the body is placed in the grave. If the latter is a belief dear to all the world, the former may well be used as its harmonious if not inevitable foundation.

In the attainment of human condition the child has a long way to go-farther than any other animal born into the world. There is more difference between the infant homo and the adult homo than between the infancy and adulthood of any other being which comes into the world. Not only is the distance to be traveled greater, but there is actually to be a translation from one kind of being into another, which does not occur with any other being subject to birth. Says Major J. W. Powell ("From Barbarism to Civilization," 505, p. 97) : "Every child is born destitute of things possessed in manhood, which distinguishes him from the lower animals. Of all industries he is artless; of all languages he is speechless; of all reasoning he is thoughtless; of all philosophies he is opinionless; but arts, institutions, languages, opinions, and mentations he acquires as the years go by from childhood to manhood. In all these respects the new-born babe is hardly the peer of the new-born beast; but as the years go by, ever and ever he exhibits his superiority in all of the great classes of activities, until the distance by which he is separated from the brute is so great 
that his realm of existence is in another kingdom of nature."

The prolonged infancy of the child not only means that he is born at the foot of the ladder and "crawls to maturity" at a far slower pace than any of the animal species; but also that he climbs so much higher. The lion is as old at three and six years as man is at fifteen and twenty-five, and yet it lives to half the total age of the man. Its infancy is only one-fifth as long; its adulthood is almost equal. Moreover, this prolonged infancy belongs only to those races of men who achieve the highest attainments of civilization. The Aleutian boy is an independent hunter at ten, and may marry. In Tahiti, children become practically free from parental control at eight, and may set up a sort of group life for themselves. (Chamberlain: "The Child," 53.) Says Tyler: "Man is a being of extraordinary complexity and of innumerable possibilities. He can rise to the heights of wisdom and power of which we as yet have little conception, or he can sink lower than any brute. He can press upward in the line of progress, can stray or straggle from the line of march, or stagnate or turn back. He has more possibilities of failure than the lower animal, and the attractions and allurements to stray from the upward course are more numerous and more powerful." ("Man in Evolution," 84.)

Lessing said that "education was revelation coming to the individual man." Spirit-formation, 
if this be true, is not synonymous with education: for the process is not a mere revelation of the outside world; because there are required certain subjective changes which condition the incoming revelation. At the first the child can take in a certain class of impressions only. Before others are perceived the very cells of the brain must undergo transformation, and the brain come to what may be called its human size. The new-born child probably does not use the front or intellectual part of the brain-only the medulla, and perhaps only the nervous ganglia at the base of the skull. ("The Child," 81.) If spirit-birth were education merely, then the time of its arrival might be noted when the child had attained some standard arbitrarily fixed. But there are certain periods in child development, fixed by nature, and they are by no means arbitrarily designated relatively to an advancing standard. These periods are attained and passed whether we note them or not, and condition entrance upon the succeeding stage. If we know what a human spirit is, and how it acts, we can easily determine when it has arrived, though we may not have perceived the moment of its coming. We can easily distinguish between the infantile and dependent being and the adult and completely responsible spirit. Nothing is more important in the administration of the home and the school and the Church than knowledge of these periods and their appropriate activities. Parental responsibility increases as childish 
irresponsibility is recognized. If the infant has not a rational spirit, the parent must discharge the functions of the spiritual life for the child. If the child of six years has not come to moral responsibility, the parent must assume before God and the community that responsibility for the child, and so on up in diminishing measure until the youth has come to the place in life where he may bear his moral burdens on his own shoulders. 


\section{CHAPTER IV}

IS THERE A MORAL BIAS IN HUMAN NATURE?

If the question be raised, Is there a bias toward sin in human nature, as we know it, that is not the consequence of actual transgression of law by the individual? we can not return an answer in a simple word. We eliminate the case of actual personal transgression: for it is conceded by all that in such a person there has resulted a weakness which gives sin the advantage in the contest.

In answering we must remember that human nature is complex-flesh and spirit, with the propensities and qualities of each in their various relations. In dealing with the new-born child we have to deal immediately, as we have seen, only with the flesh. But as this child is the individual that is to become a complete human being, we are hardly dealing candidly with the problem unless we seek to analyze human nature as it is in its developed but normal form. It might be conceded that the child needs no change of nature, but that that concession does not inevitably follow concerning the complete human being, who is the normal and inevitable development of the child. So we must face the question in its application to 
the human being that has arrived at the full form of his powers. With this understanding of our question, what shall be our answer?

First, we consider that part of human nature which we call the flesh: The animal nature certainly does furnish the conditions which make a struggle against sin necessary. It is not that $\sin$ is located in the animal nature, or that its workings are sinful in themselves. But it grows out of the fact that animalism has nothing in it but impulse. It has no self-limiting power within itself. It has nothing but a tendency to function or a pressure toward gratification.

Legitimate gratification is not sinful; but the flesh does not of itself stop at the line of legitimacy. Its only tendency, when it arrives at that line, is to push on. But the passing of that line is $\sin$; and the effort to hold it to that line constitutes a direct struggle of the spirit with the flesh. The sin that occurs from a transgression of the boundary is not a sin of the flesh-for the flesh can not sin; but it is a sin of the spirit, whose function of regency in the personality has not been made good. "Sin is no factor of the true humanity, but only a feature of empirical humanity which is absolutely fatal to the true. What is truly human is not sin, but the power to be tempted to sin. It is not perdition, but freedom." (Forsyth: "Person and Place of Jesus Christ," 302.)

So we have the paradoxical answer: the ani- 
mal nature has in it a pull toward sin; but that pull is not a state of sin or an act of sin. The state of $\sin$ is that condition of personality in which the fleshly impulse is enthroned. The degree of sinfulness of the state is a balance between the intensity of the fleshly impulse and the strength of the guiding spirit; just as the degree of danger in a horse is the balance between the animal spirits of the horse and the strength of the driver who guides and restrains him. The strength of the first, unmatched by the strength of the other, produces a condition of lawlessness and wreckage. The act of sin is the transgression of the legitimate boundaries of fleshly action. Neither state nor act is inevitable from the relation of flesh and spirit, the proffered aid of the Spirit of God being always assumed.

The question as it relates itself to the working of the spirit is still more intricate. There are certain sins that are not the result of the operation of the flesh, but are the result of the activities of the spirit itself. They are such sins as pride, haughtiness, selfishness, self-indulgence, etc.

By close analysis we will discover that these are but the exaggerated form of certain germinal, fundamental, personal principles, that are virtues. For example, self-respect is a fundamental virtue, without which character-building is impossible; but the exaggerated forms of this virtue are pride, vanity, haughtiness, etc. Paul says: "For I say through grace that was given to me, to every man 
that is among you, not to think of himself more highly than he ought to think; but so to think as to think soberly, according as God has dealt to each man a measure of faith." (Rom. 12:3.) Here it is clear that Paul allows that one should think "highly" of himself. Up to that point he is virtuous; but when he passes a certain point he becomes vicious.

Again, self-love is a fundamental virtue, furnishing the fulcrum for all moral appeal, and without it virtue would have no foundation in human motive; it would become a perfectly capricious thing. The Bible from beginning to end is full of appeals to this fundamental and normal human element. It is represented as a motive in the sacrificial career of Jesus Christ, "Who for the joy that was set before Him endured the cross, despising shame, and hath sat down at the right hand of the throne of God." (Heb. 12:2.) So that we think it is clear that self-love is a fundamental excellence in human or even in divine nature. But its exaggerated working is selfishness, in its manifold forms-a sin so comprehensive that it has been estimated as the one central principle of all sin.

Recognizing this distinction between the legitimate root-form of a principle, which is a virtue, and the exaggerated form, which is a sin, are we not able to see that here also is ground for a struggle within the activities of the spirit itself, similar to that which we have seen between the 
flesh and the spirit, and that the struggle is not of itself an indication of a sinful condition? The human spirit is to seek its welfare as an end of its existence; but the manner of the attainment of that end, paradoxically enough, is to transfer the center of its activities from its own being to the heart of God Himself. One must love himself; but when he looks for the means of promoting his welfare, he discovers that it is self-forgetfulness and mindfulness of the glory of God, of His Kingdom, and of His other children. This does not constitute a contradiction, even though it be a paradox. It is simply a revelation of the marvelous wisdom of God in His provision for the welfare of myself and my brother at the same time by a single action through an altruistic law.

That discovery, whenever it comes, will precipitate a crisis. Until the hour of that discovery it can not be said that the direct seeking of our individual good is a sin; it is only a mistake. Now, if one shall reject the operation of this altruistic law, the identical direct seeking of the good for one's self is no longer a mistake; it is a sin. But if one yields his self-seeking, he will avoid the sin and be lifted out of his mistake.

If any one shall regard this crisis and its solution as a conversion, we will have no controversy. We point out only that the change is a change in the spiritual nature, but not of moral character. There was no condemnation before; there is none after. It is a change that grows 
out of spiritual enlightenment and the workings of the already inwrought Divine Spirit. It is not a turning away from sin to holiness; it is only an essential step in holiness, and the life of God's children are full of such normal crises.

Our answer to the whole question, then, is somewhat a paradox. In the working of both flesh and spirit there is a pull, an impulse that leads toward sin, but stops short of it when the higher nature recognizes the boundaries where virtue ends and sin begins, draws the line and says that the movement must end at that line. It is a struggle with an impulse that, uncontrolled and unlimited, would end in sin, and thus it is not very far wrong to call it a struggle against sin. But it ought ever to be remembered that it is not a sinful struggle.

If one would look for a living illustration of what we have said, he may find it in the temptations of Jesus.* If struggle were sinful, Jesus, as a pure Being, could never have known the pull of temptation. That He did feel it in proportion to the wealth of His nature, the exaltation of His mission, and the power of His passion to accomplish that mission, we are ready to believe. The point of that temptation seems to be the demonstration of the truth of that testimony, which had just been given Him from heaven, that $\mathrm{He}$ was the

- Of Jesus it is said: "The only temptation with real power to Him was a temptation to good-to inferior forms of good. It was not the temptation to forsake the righteousness of $\mathrm{God}$, but to seek it by other paths, less moral and less patient paths, than God's highway of the holy cross."-(Forsyth: "Person and Place of Jesus Christ." 303.) 


\section{MORAL BIAS IN HUMAN NATURE 75}

Son of God. What was implied in that testimony? That He had creative power. Then, turn these stones into bread: for His hunger furnished a real occasion. If $\mathrm{He}$ be the Son of God, then it is very desirable that some unmistakable sign should be given to the people that they might believe it. Then, cast Thyself down from a pinnacle of the temple and let the people see that angels from heaven bear Thee up and no harm comes to Thee. If He be the Son of God, it is very necessary that all of earth's forces, evil as well as good, shall unite in the formation of His Kingdom. Then fall down at the feet of Satan; make some compromise with evil; seek an alliance with the powers of a degenerate world, and they will all join in bringing the world to Thy feet. All the objects presented in these temptations are legitimate. All of them Jesus sincerely desired to encompass, and His desire was commensurate in intensity with the passion of His nature. But the means in each case was illegitimate, and the moral divergence of means and end furnished to Him, and the same divergence may furnish to us, an intense conflict, a fierce temptation.

We then have to do in normal human nature with the double impulse-one toward sensuous gratification, and one toward spiritual or temperamental exaggeration. The flesh says : indulgence without limit; the mind says: indulgence as a means toward a higher purpose only. One of the elements of the spirit sáys : let me develop re- 
gardless of other virtues or other persons. The instructed spirit says: development can only be in God. All other growth is but losing the way, and consequently losing the goal.

There is not, then, in normal human nature a single bias unopposed, but an impulse met by a higher faculty, operating under the guidance of a higher law, and for a more ultimate end.* The condition of struggle with the flesh will end with the earth-life. The conditions of spiritual struggle are eternal. There are hints, which we may be in no situation to analyze or criticise, though not irrational in their suggestion, that angels who had not the fleshly bias at all, yet fell while in the situation of a pure spiritual condition.

If any one shall say that this discussion is academic only; that there is no individual adult that is normal, none whose nature is not damaged by some sin of his own, we will not join issue on the point. Its introduction was necessary to show what kind of a thing is the human nature which the child inherits.

To many it seems that the impulse of the flesh is too strong for the spiritual nature to resist. That if we may not use the word "bias," at least that the impulse sinward has the preponderance.

- Lydston states this truth in a little different way when he says: "It is fair to say that the human being is an animal primarily possessing instinctive tendencies to crime, but who is subjected under civilized conditions to certain inhibitory influences that have accumulated through the ages, and which prevent the average man from becoming vicious or criminal. When these inhibitions or restraints are removed, criminal act result."-("Diseases of Society," 27) He is speaking of crime, and hence speaks of external inhibitions; we are analyzing the tendency to sin, and hence bring to view the internal inbibitions. 
Hence, as a matter of fact, no individual ever passes through his career without giving way to sin. Is sin therefore a necessity of our inheritance? or how shall we explain this universal fact?

We may say that the Spirit of God is given to every man, or offered to all, to assist in withstanding the onslaught of impulse. This is accepted by all, but it does not clear up the situation. Even regenerate persons give the same general testimony: that they all at some time fall into sin. Is this, then, a disproof of the divine ability to keep one from sinning? Does this universal testimony establish a law of necessity? Has God put us under sin at our birth and furnished us with no way of escape even through Jesus Christ? To say that the universal experience proves sinful inheritance, is to allow that the same experience proves that there is no relief through faith in Jesus Christ through the Holy Spirit. This is a conclusion from which all will draw back. Is it not better to seek an explanation of the universal experience from the nature of freedom and the general influences that pervade all society, even the best-known Christian society?

"It has been concluded that regeneration so affects the will, the affections, and the intelligence as to establish in its subject a preponderant tendency toward God and His Kingdom of righteousness. But a right tendency is not necessarily one of perfect and indefectible strength. The complex life of the human soul makes it possible that the 
heavenly attraction should prevail over it, while yet it feels the drawings of the things of sense, and is in more or less danger of conceding too much to that inferior drawing." (Sheldon: "System of Doctrine," 459.)

It is only necessary to hold that sin is not necessitated; that any given experience may be an experience in holiness, as well as to allow that in the mysterious working of freedom it may be an experience in sin.

This discussion, if followed out, would lead us too far off from our subject. We leave it with the observation that any explanation that will satisfy in the case of the regenerated adults will also clarify the case of children. Their experience in sinning is no whit more universal than is that of those who have passed through adult conversion. It is a fair question for investigation whether, in the cases of carefully trained children, their record is not better than that of adult Christians. But our position does not demand the affirmation of this, and we leave it an open question. Justly Professor Tyler has said: "Appetites are old and deep-seated, rude and very strong. Man's senses are keen. Old motives, like fear or hate, are always threatening revolt against the higher and younger moral and religious ruling powers. .. It has been a long and fearful struggle. Rex regis rebellis. The king has always been in rebellion against the king. The lower always appeals from and against the higher. Ape and tiger 
die hard." ("Man in Evolution," 59.) This he says from the evolutionist's point of view. May we not hope on that assumption that the higher nature may continually strengthen, and the lower, being continually awed into obedience, may learn to be more tractable!

The question is often put in the form, Is human nature, unassisted by the Spirit of God, more inclined to evil than to good? In this form the subject is obscured rather than illuminated. Man is made for fellowship and communion with God through the Holy Spirit. We might as well investigate the physical powers of man by raising the question, What can he do without an atmosphere? When communion with God is rejected he is abnormal, unnatural, and the answer to the question, what he can do in that condition, has no significance. The proper inquiry is concerning man as God has planned his nature. We then would ask, Is man in his natural condition of fellowship with God more inclined to evil than to good? The answer even then must be: Man is in a moral struggle with his animal nature, but the issue is not uncertain so long as he maintains this living relation with God. 


\section{CHAPTER V}

\section{HEREDITY AND ENVIRONMENT}

Tоо мUсн and too little have been said about heredity: too much if mere physical heredity only is meant; too little if spiritual heredity also is considered. It is one of the unsolved problems, and agreement concerning it has not been reached. Perhaps it has never been properly conceived. Some exalt it to a supreme position; others think it may be overcome and nullified by environment.

Lewes in his "Life of Goethe" says: "It is profoundly false to say that "character is formed by circumstances,' unless the phrase with unphilosophic equivocation include the whole complexity of circumstances, from creation downward. Character is to circumstances what the organism is to the outer world: living in it, but not specially determined by it. . . Every biologist knows that circumstance has a modifying influence; but he also knows that modifications are possible only within certain limits. . . Goethe truly says that if Raphael were to paint peasants at an inn, he could not help making them look like apostles, whereas Teniers would make his apostles look like Dutch boors. Instead, therefore, of saying that 
man is the creature of circumstances, it would be nearer the mark to say that he is the architect of circumstances. It is character which builds a career out of circumstances." In dealing with such a surpassing genius as Goethe we may excuse Lewes somewhat for putting the case very strong. There is something that precedes circumstance, but it can hardly be character. And unless character does precede circumstances it can hardly be credited with building anything out of them. Ruskin ("Modern Painters," III, 42) gives even more credit to heredity, although, as we shall see, in a somewhat mixed conception. "The greatness or the smallness of a man is determined for him at his birth, as strictly as it is determined for a fruit, whether it is to be a currant or an apricot. Education, favorable circumstances, resolution, industry, may do much, in a certain sense they may do everything; that is to say, they determine whether the poor apricot shall fall in the form of a green bead, blighted by the east wind, and be trodden under foot; or whether it shall expand into tender pride and sweet brightness of golden velvet." These two sentences are hardly consistent with each other. The latter allows to circumstances what the former denies to them. A great man and a small man belong to the same species. Birth has fixed it that neither shall be of some other species. This granted, it is within the power of circumstance to modify the degree of manhood which either shall be. Lacassagne, a French crim- 
inologist, has said, "The social environment is the culture medium of criminality." But society not only fashions its criminals by its social conditions; it also produces by social conditions highclass citizens. The same law works for preservation in one direction, that in the opposite works for corruption. Its workings in the preservative line we see more clearly, however, in that form of society which we call the family, because the family has its opportunity at that period when character is most impressible and formative.* Dr. Lydston gives the following very striking illustration of the lines of destiny formed by environment: "Two boys were truants and went to a farmer's orchard to steal apples. One of the boys was caught: the other escaped. The one who was caught was turned over to the constable and placed in jail, where he was thrown among criminals long enough to fall under the influence of evil associations. When released he was much worse than when arrested, and got deeper and deeper into crime. The other boy, with whom he had gone to steal apples, remained in school,

* The first form of our Indian corn is a grass about two feet high, "bearing at its summit a handsome panicle of male flowers, and on the culm below one or two fertile spikes three inches long and half an inch in diameter, having the seeds arranged around the elongated rachis. . . This represented all that nature (heredity) could do. The vast cornfields of the West, the stalks fifteen feet in height, loaded with three or four ears, each nearly a foot in length and two or three inches in diameter, represent what nurture (environment) has done."-(Ward: "Applied Sociology," 126.)

The above is an example of improvement through the power of environment. The same author gives an illustration also of the degeneration that may be produced by environment. He tells of a grass which he found growing near Washington, D. C., pauperized but still very green, and to his astonishment, it was nothing clse than degenerated wheat. It had arrived at its present condition by having lost the care which man gives to it. 
was looked upon as respectable, acquired an education, became a lawyer, and finally a judge. Twenty-five years after the apple-stealing episode the boy who ran away and escaped punishment was the judge who sentenced to death for murder the boy who had been caught and whose punishment had started him in a career of crime." ("Diseases of Society," 95.)

A prominent preacher in Chicago said a few days ago, "We have handed down to us the ambitions and appetites, talents and taints, virtues and vices of our ancestors, just as we get from them our forms and features, our manners and voices." This is probably true, but possibly not by the identically, same heredity. The heredity of the flesh is somewhat differently conditioned from the heredity of mind. The form and feature came to us in the fleshly birth, and no matter what happens to us afterwards, they can not be wholly eradicated. But the virtues and vices of our ancestors will have little influence upon us unless we remain with them during those years when the spirit is coming to its birth. Physical heredity is about all that is given to us at birth. That which is born of the flesh is flesh. There is no sort of dispute concerning the power of heredity in the nervous system. This accounts for all that is certainly proven concerning it. The moral traits, the acquired traits, parents are not able to hand down to their children unless they also have their training. But training is usually credited to environ- 
ment. Many things are credited to heredity incorrectly, unless some broader than ordinary view is given to it. It is sometimes said, Some men were born Republicans or Presbyterians, and no earthly power can change their tendencies. On the contrary, this must be credited to training, and not to birth. If these same persons had been removed to the center of Africa at birth, they never would have had a notion of Republicanism or Presbyterianism.

But we raise the question, Is this intimate training environment, or on the level with other influences known as environment? Would it not be a better conception to think of soul-formation as the spiritual birth, and as being the spiritual heritage of the child from his parents? This would give to heredity all that is claimed for it, but would hold it to certain conditions, the absence of which would nullify it. When the eyes of the child look up into the eyes of the mother, which answer back with her own soul illumination; when she presses him close up to her bosom, and he feels in the physical heart-beat her spiritual pulsations of love for him; when prayer and solicitude ever create about him an atmosphere of spiritual dynamic that gives him courage and guidance, there is something more vital being communicated to him than can ever come from a dull and passive environment, to which he may or may not decide to respond. About the first recognition that a child has is the recognition of personality. 
"As early as the second month it distinguishes its mother's or nurse's touch in the dark. It learns the characteristic methods of holding, taking up, patting, and adapts itself to these personal variations. It is quite a different thing from the child's behavior toward things which are not persons." (Baldwin: "Mental Development in the Child," 335.) "When the child takes the next step from recognition of personality to the development of his own personality, he does so through the function of imitation. When the organism is ripe for the enlargement of its active range by new accommodations, then he begins to be dissatisfied with . . . contemplation, and starts on his career of imitation. And of course he imitates persons." Thus the soul of the child and the soul of the parent are in vital communication to a degree not existing between him and things. It is this ascertained law of vital relation between parent and child that demands some intenser name than the term environment conveys, and suggests the propriety of calling it heredity. No physical communication was ever more vital to him, even when he formed a part of the physical organism of the mother, than the spiritual tides that now flow through him from the ardent spiritual nature of father or mother. Much attention has been given to pre-natal impressions-perhaps not too much, if we are thinking of the nervous system alone. But the spirit of the mother has its supreme opportunity in the post-natal life, when the child has 
come to those human conditions where he may receive spiritual influences through channels of spirit, and not through mere blood arteries. Dr. Duvall, of Ohio Wesleyan University, allows the statement that the child grows up in the matrix of the home-life for the first nine years of his life as he grew in the matrix of his mother's body for the first nine months. The higher nature is spiritual; its period of gestation is the years when parental influences enfold it; streams of habit flow into it; bands of power are bound round it, directing its growth and controlling the spiritual nutriment that is built into its character. Let us take a single example of the invincible power of the parent, the law of Imitation. Imitation in a child is not volitional. He can not help imitating. His nature acts that way independently of choice. Yet every action performed through imitation drops some reflex back into his self-life. His self is but the product of his past actions. "What we do is a function of what we think; what we think is a function of what we have done." (Baldwin.) We thus can control the action of the child, and hence the character of the child through the actions we live before him, and the authority we have over him. Thus these years of childhood up to adolescence are much more important for character than anything known that can come to him in his pre-natal life. If this truth could be adequately appreciated by parents, they would not, as is now frequently done, allow the life of the 
street to beget the character of their child, to whom they have given only a physical structure.

If this be an allowable conception of spiritual heredity, then a child is greatly wronged whose parents do not give themselves vitally to him. They must allow the arteries of spiritual life to pump into his forming being that character which he has a right to inherit from them. The child that is brought up by nurses instead of by a mother is the spiritual offspring of the nurse rather than of the mother, and will be more indebted for character to the nurse than to its own mother. Nothing saves such a transaction from being a tragedy except the not unprecedented fact that the character of the nurse is often more noble than that of the mother. That mother is mistaken who assumes that in giving her child fleshly birth she has given him a spiritual being, which now she may have cultivated by a hired servant. Nothing but daily, living contact with herself will impart her own self to him. If separation from the parents is complete, the spiritual heritage from them will be insignificant. A spiritual heritage for our children can not be purchased with money; it must be drawn from us by living processes. A child is not indebted to his mother's milk so much for his character as he is to his mother's hope, courage, faith. "Children have certain inalienable rights which fatherhood and motherhood must recognize. They have a right to stand first in the affections, the interest, and the endeavor 
of the parents; they have a right to all that is good and noble and encouraging in the parent life; they have a right to find their home the most pleasant spot on earth; they have a right to all the means of refinement that lie within the limits of the parents' purse; they have a right to proper food and clothing for the body, but equally as great right to mental and moral nourishment, that neither body nor soul may be atrophied; they have the right to have the laws of their development, both physiological and psychological, well understood and held sacred by those in authority over them; they have a right to have their better nature so strengthened that when the seeds of evil speech and evil action fall upon their life they will take no abiding root, because the soil is already occupied with the fruits of better hopes." (MacDonald: "Child Study," 1343.)

"Nor nurse, nor parent dear can know The way these infant feet must go; And yet a nation's help and hope Are sealed within that horoscope." 


\section{CHAPTER VI}

HEREDITARY SIN IS DISPROVEN BY RECOVERY

If there is one thing we know about sin, it is that it is a waste of human resources. Its direct effect is to poison, tear down, dissipate, disintegrate, destroy the elements, power's, faculties, even the very tissue of human nature. Its power in a single lifetime to change a human being into a worse than beast is marvelous. The body becomes weak and refuses its functions, becomes incapable of its normal actions. The mind breaks down until it is dethroned, and the gross sinner must be directed and provided for by organized society. The soul loses every semblance to divinity, or even to normal humanity.

Now, if sin were hereditary, one generation would commence at the low level at which the last generation had arrived. A people whose habits were gross, whose practices were lawless, whose minds were vicious and impure, whose spiritual life was vile and unchaste, under the law of sinful development from generation to generation would be dragged down so low in fifty generations that it would take fifty generations to uplift them to the level of those who had lived under a pure gos- 
pel and obeyed the divine law. Is this true to the facts as known in the world?

Physical degeneracy is a fact that it is impossible to overlook. People who were imperfectly nourished, or whose physical habits brought physical weakness and loss, have approached the vanishing point, and many have passed it. Luxury and other physical vices have been the cause of different peoples' passing away from history. But this can not be said of moral degeneracy. If a people have so.lived as to keep up the physical resources, they show an ability to recover from the spiritual degeneracy of a hundred generations in one generation. The spiritual life of the Chinese must be pronounced as very unclean from the point of view of Christianity. So the Japanese. And yet out of the heritage of uncounted generations we find men coming in a single generation to take first rank in our leading American universities, and, having accepted the faith of Jesus, to rank among the most faithful and exemplary members of His Kingdom in our day. We may take even a more extreme example than those named. We can go into the heart of Africa and select a person for illustration. The life of the people of Africa has been astonishingly sinful, beyond all possibility of civilized people who have not witnessed it to conceive. It has never been relieved by a great moral or religious teacher. From the point of view of Christianity, and from 


\section{HEREDITARY SIN IS DISPROVEN 91}

that of any ethnic religion of history, the life of the people of Africa has been a continual stream of the most revolting and wasteful sin. The only. thing that is saved from human wreckage is the physical structure, which is found in most perfect form and strength.

And yet Bishop William Taylor brings from Africa a little child, whose heritage is this besotted life of her people for unknown centuries; places her in school; friends gather about her; by means gained through nursing and other employment she pushes her way through college, graduates in 1909 from the University of Southern California as the equal of any in her class, and takes her master's degree from the same institution the following year, and then seeks special preparation in a missionary training school to go back as a missionary to her own people. What is the meaning of this? Does it mean that sin is not a very evil thing? Does it mean that there is very little difference between those who have known its power and those who have lived above it? Or does it not rather prove, beyond a peradventure, that God allows all human beings to start on the same level morally? It was this same Bishop William Taylor who said, "There are no heathen children in the world." God is so just and equable in His ways with men that, so far as morals are concerned, each child is really in spiritual nature at the top. Every fall is a per- 
sonal fall. Children may become heathen; they are not born heathen. If the facts of life do not prove this, I am unable to interpret them.*

This question will be complicated somewhat, without doubt, by the question of environment. It will not be true that those converts to Christianity who remain in their native country, surrounded by their native people, can in a single generation be lifted out of their heritage. They will have the ways of thinking and the national habits, the prejudices and the moral practices of their people. They can not be lifted entirely out of environmental consequences until their whole race has been lifted out of them. That is another problem. The point, however, is: lift them out of their environment at birth; give them Christian teaching and Christian training, and they will take their place immediately among those of

* Evolutionary writers speak as if the Fall were an epoch in the history of the race. E. G. Henderson ("God and Man in the Light of To-day") says: "Man had reached a higher stage of development. To him for the first time right and wrong had meaning. To him for the first time belonged freedom of choice. To him for the first time was presented the upward and the downward course. But having reached the new stage in his development, he ought to have taken the uprard course, he ought to have chosen the good. He actually took the downward course. He chose evil instead of good. He turned aside from the path of progress. He fell into sin." (p. 113.) A moment's reflection will show that such a description of a race-act is and can be only a fiction. The above language is highly intelligible as the description of the act of an individual; but an individual in the evolutionary sense does not thus come "for the first time," etc. It is a race that thus emerges from the moral darkness of animal life into the moral light of a human life. The race could not fall into sin by an act. Only such a fall is possible in an individual. Such an account of the fall from an evolutionary point of view is reasonable only if we assume that at some time the race was an individual, as Genesis pictures. But that is a somewhat difficult assumption to fit into an evolutionary process. An attempt to think it through will result, we verily believe, in a rejection of the Fall as a race experience, and will leave the sinful condition of the race as the result of individual sins. 
another race whose ancestors have had the gospel for fifty generations. Moreover, while the individual can not be lifted out of his social and mental habits and practices in a generation, while abiding among those who are teaching him by example the old ways, yet, marvelous as it may seem, Christian Chinamen exhibit individual virtues of the most sacrificing type as a result of the acceptance of Christian doctrine. Chinamen died in the Boxer uprising with all the abandon to their Savior ever exhibited by the choicest spirits of any race.

In modern times there is no story exceeding that of the faithfulness of Susi and Chuma, two native Africans, the attendants of Dr. David Livingstone, who took charge of his remains after his death in the heart of Africa. The care and intelligence used in embalming his body, the resources shown in disguising it for conveyance through hostile tribes, the resistance even to the pressure of English officials to bury it on the way, the persistence when sick themselves through nine long months against obstacles and difficulties of every conceivable description, until at last they gave it into the care of relatives and friends in London, and all without promise of reward, reads like a romance of loyal-heartedness and is almost unequaled in literature. Yet these men, whose virtue shines out so suddenly and so brilliantly, had as their progenitors for thousands of years native 
Africans as degraded as sensuality can bring people and as deprived of moral light as Africa's long night is known to have been.

Thus it is seen that the human stock is not exhausted by the heredity of sin; and the only possible explanation for it is that there is no heredity of sin. Each child is directly God's child. Each child is provided with a human outfit morally, no matter how his parents may have wasted theirs.

Perhaps Lyman Abbott goes too far on the positive side of inheritance, but certainly not too far on the negative, when he says: "No man ever inherited sin. There is not any original sin. Men inherit appetites and passions, they inherit temptations, they inherit weaknesses and frailties and infirmities, but they do not inherit sin, and they do not inherit virtue. Virtue can not be handed down from father to son. . . . Weaknesses may be handed down so that it will be easier for your son to fall into sin, but virtue is victory by the individual himself, and the victory can not be won by another and the defeat can not be suffered by another. Men are neither born sinners nor saints." ("Modern Sermons," I, 6.)

And yet this does not deny the law of heredity, in which I most thoroughly believe. But it does announce that morals are not transferable from one generation to another. This generation through heredity is no worse in moral equipment because its ancestors were wicked; that one is no better because its ancestors were virtuous. He- 
redity is a thing of the flesh, of the nervous system, and hence has immense importance. God has given our children to us for fleshly weal or woe. We have much to say as to what they shall be; but we can not directly consign them to guiltiness and spiritual poverty by our sins, through the law of heredity.*

* "The purifying grace of God in human nature does weaken the power of sin, and to the degree that it loses its dominion over the flesh, (1) and its enticing influence over the spirit, to that extent is its transmissive power weakened." (2) (Cooke: Incarnation and Recent Criticism, 151.)

(1) "Power of sin in the flesh," is here manifestly intended to be understood. This would be probably true if there were any sin in the flesh, which there is not. Sin is not an attribute of a material substance. There may be disease in the flesh. Whether the grace of God weakens the power of disease, we will not discuss, because it is not relevant at this point. We can readily believe that it would, but it is simply a question of fact to be established.

That Paul speaks repeatedly of "sin in the flesh" we are aware, but even a slight examination will show that he is not thinking of the substance, flesh; but is using the word sarx as a figure of speech for a nature or person, who is giving himself to the dominion of fleshly impulses.

(2) This is an easy and at first view apparently pleasant assumption; one that has been much indulged in in recent years by different writers. But first, when heredity and environment are properly discriminated, the experience of the race furnishes no confirmation of it. It is now rejected by scientists, although the whole subject can hardly be said as yet to be worked out definitely. In the second place, if it were true, such a law of heredity would produce a condition of hopelessness for mankind. If moral qualities are transmissible by heredity, then the bad as well as the good would have their cumulative conscquences. Unfortunately the history of the race has been so preponderantly evil that such a law would long ago have brought us below salvability. However such a law would be on its upward side, the downward side must go with it, and would have placed mankind in a hopeless condition. There are few things from which we have escaped for which we should be more thankful than that the law of heredity does not include in its operation the transmission of moral qualities from generation to generation. 


\section{CHAPTER VII}

ACQUIRED TRAITS NOT TRANSMISSIBLE BY HEREDITY

IN seeking for a statement of the doctrine of hereditary sin that would fairly represent the general doctrine that has been held through the centuries, we have found a considerable variation of opinion. But Anselm and Augustin will agree in the following summary: God created human nature without sin. If Adam had not sinned, his posterity would have been without sin. But by sinning he corrupted human nature (not merely himself as an individual, but human nature, of which he was the only representative), and his posterity now partake of the modified human nature which he by sinning acquired. His acquired, not created or, as we would now say, inborn trait, is transmitted to posterity through heredity. Both these teachers make a distinction between human nature and the individual. They assume that Adam was both in himself; that he sinned, not as an individual, but as the embodiment of human nature. In this they will hardly be justified. The accident of being the first individual gave Adam no more power to modify human nature than any other ancestor, unless we assume in the start that heredity transmits acquired 
traits. Adam was as much an individual as any other that lives after him. The law of heredity will have no different effect in his case than if he had not been humanity's only representative. We dare to apply the law of heredity to him as exactly and as comprehensively as we would if there had been a thousand progenitors instead of one. It was no different law because he was the first man than if he had been in the second or the tenth generation. If the law of heredity does not transmit the acquired trait now, it would not do so then. This doctrine, then, will be much affected by our conclusion concerning this matter of fact. It has never been contended that heredity can operate to the restoration of humanity to his original righteousness; yet it is difficult to see why the law should not operate both ways if it operates at all.*

* The opposite of our contention is widely held, and even taught hy some writers appealing to puhlic influence. John B. Rohins says:

"We maintain that the hest families religiously transmit hetter qualities to their children than irreligious families; religious communities more than irreligious communities; and a religious nation more spiritual worth to its citizens than irreligious nations. These are some of the practical results of heredity."-(The Family, 129, cp. 137.)

That he announces practical sequences in the above statement is too apparent to need iteration, but that heredity is the law that accounts for it is a too swift and too unscientific conclusion to announce. The cases mentioned cover heredity and environment working together, which produce the results. But scicntific ohservation is against the conclusion that heredity alone will account for the transmission of religious qualities.

His Biblical illustrations are not much, if any, better than his scientific foundations. He refers to the persistence of race qualities in the Jews. These qualities, however, persist only while they remain under the peculiar Jewish environment and training. Many Jews have left their race connections, have married with Gentiles, and given up their religious culture. Does any one presume it to he possible to trace the hlood stream of Jewish parentage out into the Gentile peoples? The illustration proves that as long as you maintain the Jewish environment, Jewish types persist; but heredity has no power to perpetuate them as soon as this epvironment is ahandoned. 
Saleeby says, in his very recent (1909) work on "'Parenthood and Race Culture:" “' Heredity,' by Professor J. A. Thomson, is the most recent and most valuable (work) for general purposes of all books on the subject of heredity. No layman should express opinions on heredity or eugenics until he has read it, for it is extremely improbable that they will be valuable." We shall agree that this is a subject which must be submitted to the testimony of experts. We need not transfer Professor Thomson's extended argument. The subject has been surrounded with various misunderstandings. These he undertakes to clear away. Having done so, he lends his authority unquestionably to the side that acquired traits are not transmissible by heredity. We permit ourselves the following extract which he quotes from Thomas Fuller, "Scripture Observations," No. VIII. It puts our question in a vivid form:

"Lord, I find the genealogy of my Savior strangely checkered with four remarkable changes in four immediate generations.

"1. Roboam begat Abia; that is, a bad father begat a bad son.

"2. Abia begat Asa; that is, a bad father, a good son.

"3. Asa begat Josaphat; that is, a good father, a good son.

"4. Josaphat begat Joram; that is, a good father, a bad son.

"I see, Lord, from hence that my father's piety 
can not be entailed; that is bad news for me. But I see also that actual impiety is not always hereditary; that is good news for my son."

The idea that acquired qualities are transmitted to succeeding generations lends itself readily to the imagination and passes from one speaker to another to adorn many a theory. It has become very current in connection with popular conceptions of evolutionary theories to account for the mutations of species in successive generations. It has been oft repeated as a self-evident truth that "the giraffe has attained its long neck by stretching it for many generations; swimming birds have got webbed feet because they stretched their toes in the water; wading birds have got long legs because they stretched them; the mole has very small eyes because it has ceased to use them; the whalebone whale has no functional teeth because it has acquired the habit of swallowing its food without mastication." This sounds much like evolution, and evolution is a victorious theory; therefore this must be taken for granted. Yet it is not believed that the long neck of the giraffe is due to the stretching; but rather that the stretching is due to the long neck. That is, a new species of animals had a start in the leaf-eating direction by the modification of an animal born with a neck longer than usual, from some cause to us untraceable - a cause certainly not traceable to the acquirement of its ancestor. The start was not due to environment, but to the selection of ger- 
minal variation in heredity, which variation, however, fits into the environment, or the animal manifesting it would perish and the tendency proceed no farther.

Mutilations, such as dehorning cattle, cutting off dogs' tails, binding the feet of Chinese girls, circumcision, ear and nose-boring among savages, continued many generations, have had no influence upon offspring. It is conceded that any modification that does not affect the germ cells has no tendency to influence children.

The popular belief that moral qualities are hereditary is due to the fact largely that heredity and environment are not often separated. These two influences combined are usually able to reproduce the moral character of the parents. It is often believed that children of drunken parents are predisposed toward inebriety. This is a case rather different from the transmission of moral traits. The popular belief is probably not well substantiated, and other factors than acquired traits are involved. "Intemperate habits of parents may be the expression of an inherited psychopathic disposition, and it is this which is transmitted to the offspring." Children of drunken parents grow up in a drunkard's home; often are fed on alcoholic drinks from infancy. Moreover, there are facts of heredity that make credible the idea that a toxin or anti-toxin in the blood of the father may have its effects upon the child. Alcohol has an effect upon the whole nervous constitution that 
might easily be transmitted. In this case it is not the moral quality of the act of drunkenness that is transmitted, but the physical effect of alcohol, producing degeneracy of the nervous system, showing itself in some physical weakness in the child. But even this is still in the region of controverted theory, awaiting confirmation. "Most of the babies born in the slums are splendid little specimens of humanity - so far as physique is concerned-bearing no marks of the degeneration of their parents. In a word, heredity works-the racial poisons apart-so that each generation gets a fresh start. If there be no process of selection, each new generation begins where its predecessor began and is as a whole neither worse nor better, whether physically or psychically." (Saleeby, 22.) The famous Jukes family of New York State has so often been quoted that it is well wrought into the belief of people that bad parents have bad children through the power of heredity. In this case, however, there was first of all a degenerate physical heritage producing its inevitable crop of insane and degenerate criminals. Concerning this physical inheritance there is no dispute; but this case in no way substantiates the claim that wicked parents have wicked children through the power of inborn moral inheritance What children of this family escaped a physical degeneracy were kept in a corrupt environment, which insured the moral reproduction of the parents. The law of moral heritage can only be 
shown in those cases where no physical deformity is known in the parentage, and where the offspring is removed from the evil environment established by the evil parents.

The doctrine of the heredity of the spirit from our parents must assume that the disposition of the child will be like that of the parents. If this were a true assumption, then all children of the same parents would be of like disposition and have the same moral qualities. This is not even approximately true. Again, an analysis of the moral and character qualities of the parents does not account for the moral constitution of the child. Abraham Lincoln was a conspicuous example of one who can not be accounted for by his parents. The biographical mystery of his personality, so often mentioned, would no longer hold the attention if the assumed law of heredity should be put aside as invalid. Who can account on the basis of this law for the fact that Aaron Burr, the greatest moral degenerate that America has ever produced, is the grandson of Jonathan Edwards, the greatest spiritual genius that America has yet produced?

Still there are noticeable resemblances between children and parents. Musicians are often the children of musicians; many other instances of resemblance may be noted. (1) The influence of environment may account for most of this. We do inherit from our parents a physical life. The peculiarities of this physique show them- 
selves in our nervous constitution. This nervous system in contact with a certain environment will seek the lines of least resistance, which should produce great similarity in developed personality between parent and child. The physical predisposition of the child is likely to follow the same or similar lines that were taken by the predisposition of the parent: The musician will have very delicate, susceptible nerves. His case is somewhat complicated. Musical temperament implies both heredity and culture. The delicate nervous constitution-a thing of the flesh-must be inherited; it can never be acquired or produced by any reaction on the environment. But to be a really great musician-especially a vocalist-one must also have a great, a cultured soul-a matter of the spirit, which comes only by culture and environment. Some fine, nervous temperaments, able to give the technique of music, need a broad literary education, that they may have great thoughts to express. Other physical constructions are favorable to a certain course, as they react on a certain environment. This seems adequate to account for all that is proven concerning the inheritance of disposition. On the other hand, from the same family will come children of the most diverse temperaments - an utterly incomprehensible fact from the old theory. It is well established that the moral and religious acquirements of parents in the direction of righteousness can not be transmitted directly. They must be 


\section{MORAL CONDITION OF THE CHILD}

independently acquired by the child. It would be strange injustice that God had put us under the operation of a law by which we could inherit the sins of our parents, but could not inherit their virtues.*

The persistence of a similar environment through several generations may produce the semblance of heredity without ever establishing it in the least degree. "The Alpine plants which Naegeli transferred to a southern garden were changed by their new surroundings; their descendants were likewise changed, and the new

* All will admit this kind of inheritance, There is no trouble in regard to characteristics that are evil. All admit this kind of inheritance. 'Like begets like.' The books are full of it. Adam sinned and begat a child in his own sinful likeness. All other Adams have done the same thing. Here heredity serves a good purpose. It furnishes a foundation for all our theologies and theodicies. . . . Has God made it possible for us to inherit irreligion, or an evil nature, and not made it possible for us to inhcrit religion, or a good nature? If so, then why did He make us creatures of inheritance at all? Would a wise and good God place in our natures a law that becomes effective only when, and as soon as, we become evil? Would it not have been better to have left this law out altogether?"-(Robins: "The Family," 142, 143.)

The possibility that this latter question might have an affirmative reply did not seem to have entercd the mind of this author. His argument cuts the ground from underneath himself as well as from underneath those whom he combats. Science says that neither virtues nor vices, as moral qualities, are hercditable, and hence God is vindicated as thoroughly as in his conclusion that both are transmissible. But from his point of view, that of the heritage of original sin, his argument is very effective.

This author, and doubtless many others, base their belicf upon Exod. 20: 5, 34: 7; Num. 14: 18, in which it is said that God visits "the iniquity of the fathers upon the children, upon the third and upon the fourth generation." They take this as a statement of the law of hcredity. Such, however, it is not. It is a social law, and in the form in which it was practiced in that period of society is indefensible to-day. It will be noticed that it is not a law of hercdity, which wovld never run out in its influcnces, but it covers just generations cnough to comprehend those who might at the time be living with the father-criminal at the time of the commission of his crime. It is not hereditary in its character: for it does not specifically apply to those who are to be born after the commission of the crime, but to those who may be already living with the sinner, and presumably participants in his dced, or sympathetic with it afterwards. The commentary on this law is the cases where sinners were punished with their wife or wives, their children and relatives, and even their cattle. It in no sense is an anticipation of the modern law of heredity by which the very physical stock of a man is degenerated by some race poison, and its effects handed down to his posterity forever 
characters reappeared with constancy generation after generation. But this was acquired or modificational, not heredity or innate resemblance, as shown by the fact that removal from the garden to poor gravelly soil was followed by a reappearance of the original Alpine characteristics." (Thomson: "Heredity," 184.) So a parent whose upright character is due to his environment may be the father of a son, who in similar moral influences is like him. That sequence kept up for a few generations, however, would have no effect through heredity to keep a son from evil character who was brought up under evil influences during the formative period of his life. We can transmit to our children human nature, which is in itself neither moral nor immoral. Environment makes the child moral or immoral, without regard to who was his parent, in so far as any influence outside of his own freedom accounts for what he is.

James Harvey Robinson, professor of History in Columbia University, says: "Almost all biologists now agree that acquired characters are not transmitted hereditarily; for we do not come about in a way to permit this. The assiduity of one generation in acquiring increasing culture or its lethargy in neglecting the heritage of the past does not affect the minute egg from which the next generation springs. Culture does not get into the blood; not even language, man's earliest characteristic achievement. Had Aristotle him- 
self been reared among the chimpanzees he might have been a Gruebelkopf, but he would not have known how to talk." ("Survey," May 6, 1911.)

The impossibility of handing down any positive moral traits is apparent again from the nature of the content of consciousness. In our nature there are certain powers capable of receiving and dealing with that which comes to us from without. This is the gift of heredity. But this power innate does not of itself furnish itself with any material to work with or to build into character. That must all come from the outer world. The soul is at first an empty chamber with no hidden inhabitants in secret closets which after a while present themselves to it. Says Baldwin: "There is no question in psychological circles today of the absolute mental creation which was formerly assumed. The newer doctrine of 'mental content,' on the one hand, which holds that no elements of representation can get into consciousness except as they have been already present in some form in presentation; and, on the other hand, the doctrine that the activities of consciousness are always conditioned on the content of presentation and representation present at the time-these positions make it impossible to hold that the agent or mind can make anything for itself 'out of whole cloth,' so to speak." ("Social and Ethical Interpretations," 100.) One may say, indeed, that these powers forming consciousness are weak or defective; but that is quite dif- 
ferent from saying that they are sinful, which involves a voluntary element.

But after all we persistently believe in the heritage of a disposition that is born with us, to which we attribute the moral course of our life. We need not deny the reality of disposition; but we need to give more attention to its interpretation. What are the elements of the disposition with which the child is born? We answer: $\mathrm{He}$ is social, curious, imitative, active, etc. Among these qualities there is none that can be identified as sheerly evil. What, then, is an evil disposition? How does it arise? There is a certain average of qualities which we call human nature, the possession of which is thought to constitute normality, and is sometimes called "horse sense," because we have no proper term for it. Baldwin, seeking a term for it, calls it "average social judgment." Deviation from this is called peculiarity of disposition. The difference of disposition depends upon the preponderance of traits. It might remove some presuppositions from our mind if we should compare the "average social judgment" of the various races and peoples. What a different thing it is in China from what it is in America! How different in civilization now from what it was a thousand years ago. This might indicate that its standards are quite under the power of education and environment, rather than an invariable innate something.

How do individuals vary from this human 
standard of character? By heredity and education. One is born so defective mentally that he can never keep step with society, and we call him an idiot and place him in an institution to be cared for. The aberration of another is not in the same direction, yet he is against the standards of society; will not comply with them; interferes with the rights of others. He is a criminal. Some of these we kill; some we imprison for life; some we undertake to reform. What is the matter with them? Why are they as they are? Well, some of them are born with this disposition. Is this disposition a positive element in their nature, or a defect, a minus quantity? Confining our answer now to those born with the criminal disposition, we believe it is a minus, not a plus quantity. They are not born with a whole human nature plus something which we call sin; but with a human nature in which something is lacking. Miss Maude E. Miner, secretary of the New York Probation Association, says in the Second Annual Report concerning the girls coming under the custody of the society: "The large number are not guilty of moral obliquity because they are naturally bad, vicious, and depraved. In my work with girls in and out of courts and prisons during the last five years I can truthfully say that I have seen very few girls who could be so classed. In comparison with the total number few have chosen the life deliberately. The general truth is that they have drifted into a life of vice through weak- 
ness of will or through domination by a stronger will, and have gone down enslaved by drugs, drink, and 'the life' itself. Many of the girls are weak-willed, and in some instances weakminded, and they have not had the normal resisting power." ("The Survey," May 27, 1911, pp. 337,8 .) Let one stand before a company of men in a State reformatory institution assembled for chapel exercises. If one has not studied the situation he will experience a surprise. These men, for the most part, are not the bold, reckless, bravado, daring fellows that he expected to see. They are not in possession of all that average men have, plus an element that leads them to defy society. They are weak men, defectives. Calling them men, we see that they are not fully men. Being less than men, we call them effeminate, although we do not apologize to the ladies. They have not full, broad jaws, but rather undersized, receding chins, showing them defective in willpower. Instead of round heads and square foreheads, they are thin between the temples. Their eyes are restless and unsteady. They are not all so; for there is another class here also. But we may rightly conclude that those who have the right to the charity of judgment because of heritage are, as we have described, with different variations showing the same general defects. The others that show the lion's strength, whom you would not want to meet in the dark, we may reasonably believe are they who have been trained 
to crime. Their environment, not their inheritance, has been their ruin.

If under the head of disposition we are thinking of the born genius, it is yet a debatable question whether his genius is due to strength or weakness, a plus to average human nature or a minus. While forming an opinion on this question, let one study Edgar Allan Poe, our greatest American poetic genius, and answer the question for himself. At any rate this matter of disposition does not seem to be a direct moral equipment, indicating a certain attitude of the will; but rather something seated in the physical equipment of nerves, or that which sustains the nerves, either in the brain or the viscera. These are subject to hereditary laws, with all the moral advantage or disadvantage that they imply; but the moral or spiritual qualities so often accredited to heredity are not directly derivable from ancestors. Born dispositions are imbedded in the physical qualities ; moral dispositions are personal acquirements of life.

Other differences of disposition, not classified as degenerate or criminal, are simply the preponderance of certain traits or their absence in usual size, and are rationally traceable to the physical equipment or the culture of the physical or moral nature. One has a different disposition when drunk from that which he has when sober, when tired than when rested, when hungry than when satisfied. As one may strengthen his arm by ex- 
ercise, so he may his sense of justice, or purity, or honesty. Why he emphasizes this or that in his growth is as mysterious as why he chooses this or that avocation; but it is just as little traceable to heredity. No man is born a lawyer; no man is born a hero.

The transmissibility of Adam's sin or its moral effects can not take the form of transmission from the individual father to his son; for of such transmission there is not the slightest evidence. Indeed, it is not thought of in that form. The form of its popular belief is that the whole human race now occupy a common level of depravity, and that individual exhibitions of wickedness are chargeable not to the nature derived from one's immediate ancestors, but to one's choice. Each individual, unless evidently a degenerate, must bear his own moral responsibility. Logically, then, the conclusion which this popular belief must draw is that, as a consequence of Adam's sin, God gave to the whole race a different and a lower moral constitution than it had possessed before.

As thus conceived there is no possibility of investigation: for we have no knowledge of what the constitution of the race was before the assumed fall. But the conclusion can not be upheld on the foundation of heredity: for the transmission of moral qualities, which of course are acquired, is not provided for by the working of heredity. The belief must rest upon a special act 


\section{MORAL CONDITION OF THE CHILD}

of divine judgment, by which God visited moral calamity not only upon Adam, who had sinned, but upon the individuals who constitute his posterity, who had not sinned. To say that "in Adam's fall we sinned all," is a moral and metaphysical confusion of thought no longer permissible. The belief, then, has no foundation in any known law; it is held in the face of our estimate of justice, and attributes to God what the universal consciousness of mankind condemns in men; we must say it is arbitrarily held, with no support save the inertia of a past credulity.

That God should have lowered the physical efficiency of the race is a possible conception, based upon the law of heredity, whose justice we shall in a moment consider; but even this does not imply that into the constitution of this fallen race an active principle of sin was injected which made inevitable all the acts of sin committed by men in all history. To go so far as that is a serious charge against Deity: for such a fiat is something more than a negative act-something more than withdrawing from man some power or efficiency which he had before. It is the creation and implantation of an active principle of evil, and in making man a sinner served not the ends of divine justice, but the purposes of his Satanic Majesty. In so far as it transcended Adam's personality in its effects, it was no corrective of evil in him, while it worked an indisputable injustice to all other men. 
The workings of the law of physical heredity we can not gainsay. Whether we can construe it or not in our apologetics, it remains an unquestioned fact. But we surely need not make the problem more difficult by any exaggeration of the facts. We should carefully study its workings and know its extent and limitation before we make it a problem or feel the need of its defense.

1. God has written it in the constitution of humanity. It is an implication of the solidarity of the race. However much trouble it may seem to have caused, its blessings are beyond all measuring. Indeed, the race as known is an impossibility without it.

2. It tends to betterment. By its workings defectives come to such a point that at last they drop out, while anything in the direction of perfection tends to greater stability and greater reproductiveness. So that we may say: the law weeds out the poorest and preserves and increases the best.

3. While the race is physically a unit, morally each individual is a unit, subject to influence from others, but not to complete mastery. So the very nature of morality is such-having at its heart individual freedom-that there is no ground for desiring that moral character be subject to heredity or believing that it is. 


\section{CHAPTER VIII}

\section{THE PERIODS OF DEVELOPMENT}

There are certain natural stages in the development of the child, but they vary somewhat in different children. Their noticeable expression depends much upon the influences that gather about the child at the time. So many items are involved in this development that their grouping is more or less arbitrary, and hence different authors may vary much in their delimitation and classification. We will name the following periods and will seek only such description as suggests the opportunity of moral impression. In this, however, it is easy to make mistake by omission. We are coming to see more and more that every physical fact may have some relation to moral change as it does to intellectual. We note also that certain developments cross the lines of division and characterize two or more periods: 1 . First childhood to the seventh month; 2. Second childhood to the end of the second year; 3 . Third childhood to the end of the seventh year; 4 . Later childhood, from the seventh to the twelfth year; 5. Adolescence. Our subject does not directly carry us farther than later childhood; what we shall say of later periods 
will be guided by the purpose only of showing the fruitage of childhood training and guidance.

\section{Section I. The First Childhood.}

The new-born babe is a very interesting being, but very helpless and very insignificant in his attainments. He can see nothing, can hear nothing, and can feel no sorrow. It is probable that in all the actions of which he is capable he could get along quite as well with a spinal cord and could dispense for the time being with his brain. Nature has done very much and very little for him: very little in present realization, very much in giving him a capacity for becoming. A fly, a bee, or a mosquito is born comparatively complete, ready for business at its first salutation. Any one of these can take up its life-tasks and make its way immediately. It knows everything it ever can know; it can do everything now it ever can do. The penalty, however, of this full equipment is that it can never become; it can never learn anything; it can never change into any other condition. All the resources of its whole lifetime are immediately available; nothing will ever be added to them. Not so the child. He has no complete instincts, so that he can do scarcely anything with their help; and he has no reason or thought by which he may make his way. But his capacity to become is boundless. He knows nothing, but can learn everything. He is next to nothing; his ca- 
pacity to be can be measured only in divine units of being. The psalmist's conception is justified by the latest conclusions of research: "Thou hast made him a little lower than God." "The baby lives in a sort of coelentareate stage of almost vegetative life. His whole business seems to be to eat, digest, breathe and sleep, to survive and grow. His education consists very largely in making his physical'surroundings as favorable to bodily health as they possibly can be. But the baby gives dim promise of something higher and better. ... He kicks and wriggles; he will soon run and walk. The young child wishes to be continually in motion. He can not sit still long. The muscular system is the seat and center of his development. . . This muscular exercise is lifting all his vital organs, heart, lungs, digestive system, and is giving him the first elements of power-a tough body. It is tuning up the nervous system and stimulating the brain. . . . He is still in the muscular stage, but curiosity and wonder and some thought show the dawn of the era of mind which quickly follows." (Tyler: "Man in Evolution," 87.)

The first childhood is the period of the first dentition; it is the instinctive period. Virchow calls a child at this stage a "spinal reflex being." He has a purely reflex activity up to about the third month. That means that his actions have no volitional element, and consequently no moral quality, any more than the motions of a frog un- 
der an electric stimulus. The baby: comes into the world with an apparatus ready to act as if angry; but such action can have no moral significance. Preyer likens the early cries of a child "to the peeping of a chick breaking its shell, or the bleating of a new-born lamb, and observes that they have no more intellectual or emotional significance than the first cries of these animals. They are produced as well by a child without a cerebrum as by a child with one. The basal ganglia and the appropriate stimulus are all that are necessary on the neural side for their production." (Major: "First Steps in Mental Growth," 282, 3.) However, the cries soon come to have the value of expressing hunger, pain, cold, discomfort. The first step in the development of the sense of sight is the perception of light, which is soon after birth. This is followed sometimes as early as the fourth day by the ability to hear sounds. Light reflected from bright-colored objects will be noted. The co-ordination of the muscles which direct the eyes, the fixation of the eyes upon objects, and following the objects with the eyes, are the next steps in sight development. This has been observed, and therefore clear visual perception established, when the child was from one to two months old. Among objects which attracted the child first and most was the human face; the mother's face and voice may be known within two months. When two senses work together they hold the attention more closely than one working 
alone. We emphasize the importance of this early recognition of the mother because, as we have argued in another place, the spirit of the child is to be formed by the spirit of the mother chiefly, and before any other object begins its work the mother has gripped the spirit of the child and has begun her work. Very early he differentiates the character of sounds, whether agreeable or otherwise, and is soothed by gentle sounds and distressed by harsh sounds. The ear is the sense organ through which the nervous system is most powerfully and profoundly acted upon. Loud or sudden noises produce instinctive fear in the early days. True or genuine fear, however, is not possible to a child under three or four months; for that implies a definite idea of evil or danger. A child that has suffered much is more likely to show these apparent fears than one that is stronger and healthier. This fear is excited by sudden changes, and fear of strangers is sometimes awakened when he is four to twelve months old. Thus again nature is shutting out the strange world and locking him up with his mother and the family life where he is cherished and whose right it is to fashion his soul.

The following general remarks have their application as well to later periods; but they are introduced here because they are not inapplicable to this earliest period. Perhaps the most important thing to be noted in the very early period of life is that "habits of feeling" and fundamental 
tastes may. be formed and modified. Feelings lie quite close to the instincts. For this reason it has been thought that they could not be changed. But even the instincts of animals can be modified. A chicken, if not given the opportunity to follow within the first few days, will never develop it; or, if opportunity is given, will learn to follow human beings. When quite young an animal may be made vicious by teasing, which by kindness could be made docile and kind. A colt may be so fooled with as to be almost useless afterwards as a horse. So the habitual mood of a child may be turned this way or that to a very essential degree. A child may be teased into habitual suspicion. He may be nagged into habitual defensiveness. A great battle in after life may be brought about by the carelessness with which he is handled. Many people handle babies as if they were playthings, entirely for their own amusement, regardless of the present or permanent impression on their nature. They do not forecast the permanent twist made in the disposition by their thoughtless actions and words. Yet there is no future time when the impressions made are so deep and, therefore, so permanent. Thoughtless hands should never touch a child.

Character's formation is largely the question of the acquirement of certain tastes. When these lie deep down in the nature they will load the balances of the great decisions made in life between the right road and the wrong. Does a child 
love the beautiful, the true, the chaste; does he love to study, to investigate, to discover facts and truths? Each one of these tastes is like a hook on which may be securely fastened certain moral appeals in the after life. Appeals have influence not because of their own weight and justness, but rather because of the reaction that the nature makes to which the appeal is made. So in the first or second childhood we are arranging the conditions on which future conquests may be secured. This chance lost, and after-efforts will have little effect. Habits, which are originally merely habits imposed by the parent, come later to be rationalized, adopted, and made the basis of feeling and intellectual attitudes.

\section{Section II. Second Childhood.}

Many conceive of the nature of a child as an infolded being like a rosebud. The petals, the stamens, and every element are already there in the form in which they will afterwards be manifested. One may take the rose and analyze it and find all of these parts as they will afterwards appear in the complete rose. It may change its color and acquire toughness of texture as it opens, but nothing new will be added to it as it unfolds. Such is a rather popular conception of the child. Many do not conceive of the possibility of adding anything to his nature or putting anything into his character. They think of the child as having a 
certain spiritual form, given to him through inheritance, and there is nothing to do but to give him a chance to unfold. At about fourteen years of age he will have acquired the power to give the real and final expression to his nature, which he will do notwithstanding any influences that may have been brought to bear to change him. Indeed, they think that any interference with his spontaneous development would be likely to mar him, just as any manipulation of a rosebud would permanently mar its potential beauty. Parents accepting this theory of the child-nature object to teaching him practices or instilling in him habits that anticipate his ultimate choices. They would not approve of infant baptism, or the learning the forms of prayer, or church-going habits, or anything in general of a religious nature that is not his personal choice.

This assumption is certainly of the greatest and most fundamental importance. If true, there is little significance in the parental function. To have given the child physical birth and to provide physical sustenance and educational opportunities is about all that a parent can do. The people who adopt this view do not apply it in its educational form. They do not wait to see what is in a child's mind before sending him to school. On questions of mathematics, logic, or history they would not submit the decision to him. It is apparent, even to those believing this general view of the child, that the mental life is rather 


\section{MORAL CONDITION OF THE CHILD}

empty until it is filled. But by some rather exceptional mode of reasoning they are ready to act on this theory concerning his moral and religious nature.

The view is just as untrue morally as it is mentally. No doubt at birth there are certain elements given that can with difficulty and only partially be changed. These are all implications of the nervous constitution; it will be very hard to modify that or defy its workings. If we know the nerve weaknesses we may protect him at that point and secure to him a different and a longer career than would be afforded by the average environment. The nerve qualities will aid or defeat the avocation in life. They may make possible or impossible the career of a musician, and modify to a degree the possible success in various other pursuits. But it is quite an extreme to say the child is a born musician, or poet, or mathematician. It is better to think of him as an empty vessel of a certain size and texture. He is made so that he can hold certain things and a certain amount; but the vessel has nothing in it yet. It will never have in it anything that is not put in it. It will be very hard to put into it something that it was not made to hold, or to make it hold more than nature constructed it for. Yet no one in advance can profitably estimate the charactercapacity of a child. I think the prognosticators would have missed it on Abraham Lincoln by very large measurements. We can not make a brute 
of the child-unless he is born an idiot; we can not make him an angel. But somewhere between these limits he will be what we put into him mentally and morally. His boundaries are set by human nature; but inside this limitation we may put in the moral qualities that we choose, provided we will work according to the law of his being. The strength of the animal impulse will give the conditions of the moral contest which will ensue; but for the spiritual side of that conflict we may equip him. If this be the true view of human nature, then the parental function is as essential morally as it is physically. Physically the parents give to him being; morally they may also give him well-being. He will perish physically if they do not supply him material food; he will just as surely perish spiritually if they do not supply him with spirit-food. As both parents are essential to his physical existence, so both parents have an essential part in his spiritual building. The function of the mother in rearing the child is generally conceded; but the elements that a father contributes are not so usually observed. A boy is wonderfully handicapped who loses either early in life. The kindlier qualities, the elements noted in good manners are apt to be unacquired unless a mother-love shall instill them. On the other hand, the deeper elements of honor and moral endurance are not acquired so easily without the father. A shell of respectability will be built up in a boy who grows up with women; but 


\section{MORAL CONDITION OF THE CHILD}

he will be unreliable in the rugged struggles known to public life-I speak of tendency, knowing well how successfully certain fathers and mothers have overcome their difficulties when compelled to work out the problem alone.

This view of the child increases immensely the parental responsibility and accentuates the importance of influences received as early as the period we are now studying. He is now receiving elements of life, real character-stuff, through eye and ear, and nothing capable of making an impression upon him is unimportant. The child in this period learns to walk and to talk; mastication begins, which is the first break in his close physical connection with the mother-life. These powers indicate the broadening of the sources of influence that reach him. Hitherto he could receive only those influences which came to him; now he can go after impressions, and when they are not apparent, can ask for them. While at this time the majority of the higher animals-also automatic idiots-have their mental development arrested, the child parts company forever with them; for he is now beginning in real earnest that mental growth which distinguishes him from them. The social life is now established and will grow more and more. Fear and anger, the animal emotions, are very early exhibited. If the fear is allayed or dispelled, its exhibition becomes rare; if the anger is never allowed to avail anything, it be- 
comes very infrequent. Affection and sympathy, the higher emotions, come later; and compassion, one of the highest emotions, does not appear until near the close of the period. Different authors have noted the evident sorrow of the child when the picture of a man was cut into by a pair of scissors. These higher emotions, being encouraged, grow rapidly and become habitual.

Among intellectual qualities, attention, memory, volition, and somatic consciousness, powers shared by the lower animals, are first developed, while active imagination and reason, the essentially human powers, are the last to be developed. Some idea of number is now shown. Imitation, the power which is of so great importance through all the years of parental guidance, now appears. It is the spiritual hand which the child outstretches and with which he takes to himself all within sight and hearing. It is deeply imbedded in the nature; arises as an impulse previous to reason and volition, so that he can have no choice; lie must imitate. Before reason or volition can play any great rôle this activity has the child's development in its grip and reigns supreme. Its causal law is, "The idea of a movement is already the beginning of that movement." The idea is not completely known until it has been experienced. In other places we have called attention to the advantage that it gives the parent. We need not dwell further upon it here. The 
period of the creative imagination begins now and extends on to the tenth year. Its importance will appear in the next period.

\section{Section III. The Third Childhood.}

The Third Childhood extends from the end of the second to the seventh year. In the work of parental direction of character-formation this is undoubtedly the most important period of all. It has been preceded by a physical foundationlaying; it will be followed by other periods important in child self-direction; but this is the golden opportunity for the work of parent or guardian spirit. Imitation and authority have their fullest operation now, the two arms which may encompass the child-life with a fair degree of absoluteness. The important physical changes are the second dentition and the arrival of the brain to its full size. He is now slowly growing out of the absolute domination of the emotional element. In the ideal imitative period, from the fourth to the tenth year, he is building with the best material that is within his observation, and with the power of a creative imagination which runs through the same time he is dissecting this observed material and building up its elements into a life-castle of his own. He will not rebel at authority if consistently and unvaryingly applied. He is now forming habits that lie at the deepest foundation of his life, which like guard- 
rails will fence the whole subsequent career. Blessed is the child whose parent now recognizes and conscientiously uses his opportunity, which is very ample, but once passed, can never be recalled.

Imitation precedes the acquisition of language and is a powerful aid in its acquirement. Indeed, language is acquired through the imitation of sounds. While imitation is an activity which the lower animals exercise, and is sometimes accounted a power of low grade for that reason, yet in the forms above mimicry only self-acting beings or souls imitate. Not only is language its product, but habit is also: for habit is nothing more than self-imitation. Underneath it lies a power which gives it all the greater effect in character-formation, the power of admiration or love. "The individual sees ideals before him and impersonates them; loves them, and imitates them. Gradually he acquires as a second nature his ideals, and must keep growing on into new and higher ideals." Thus imitation is based on love, and it is emphatically true of the actively appropriating nature of a child that what he loves he becomes-as true as that other law: what he does he becomes. Imitation plays an important rôle from another point of view : it is a sort of emancipation from a self without content to a self which he admires. Here, as everywhere, nature abhors a vacuum. Imitation is powerful again, because it begins so early, about the fifteenth week, and holds its compelling place on until rea- 
soning has crowded it from its regnant rule in the adolescent years.

As we analyze this imitative activity we discover there is a slight tendency to imitate things, as an engine; but much more to imitate persons. Another important element of this tendency is that the child imitates the adult much more than other children or animals, and the imitation of adults increases with the years up till eleven years of age. Thus the Almighty has given the parent an advantage over any competitors in influence during these years. Neither things nor animals nor undeveloped children can take away the child from the molding influence of the parent. There are tied up in this law unmeasured possibilities for the good of the future generation.

The Creative Imagination: the Romancing Period.-We adults are learning that we do not live under the intellectual dominion purely of the world of objective fact. The mind is constructive. Its ultimate construction is limited by the material that comes to it from without; but the form in which it builds and the arrangement of the mental product is by no means identical with the objective material. We are idealists, to whom the objective world furnishes the bricks and mortar that we are using in building our castles, which are the true home of the soul.

It is not wonderful, then, that it is quite easy for the child to be estranged from the literal facts of sensation and perception. By himself he will 
construct a world for himself, and others can greatly aid him. The elements of this imaginative world are supplied by ears and eyes. The mind never imagines anything the elements of which it has not experienced. But the use he makes of these elements is not the same that a mirror makes of the objects supplied it. With an old hat on his head, a glove on one hand, and a basket loaded with a few toys, he will make a journey to the farthest limits of his habitable orb without ever going out the door. What an opportunity does this activity afford the guardian spirit of his life to direct in his world-building by supplying ideal and beautiful material out of which a soul-enlarging world may be constructed! What an opportunity it affords to careless or mischievous minds to furnish material for a world of terror and vice! Charles Lamb recalls the time "when through the ignorant officiousness of his old nurse, whose disciplinary methods were worse than the faults she sought to correct, as well as the terror-starting illustrations of his father's Stackhouse Bible, night time, solitude, and the dark were his hell; for from his fourth to his eighth year he never laid his head upon his pillow without an assurance, which realized its own prophecy, of seeing some frightful specter." Goblins and ghosts are more accessible instruments of torture, and by no means less effective, than the rod with irresponsible, conscienceless, and thoughtless parents and others. The applica- 


\section{MORAL CONDITION OF THE CHILD}

tion of the rod might have been beneficial, even if cruel and needless, its hurt would have been temporary; but the goblins and ghosts will never let up their stings and starts while life shall last. Burns catalogues his infant tormentors as "devils, ghosts, fairies, brownies, warlocks, spunkies, kelpies, elf-candles, dead-lights, wraiths, apparitions, cantraips, giants, enchanted towers, dragons, and other trumpery." One wonders what else could be outside of this list. He said: "It had so strange an effect upon my imagination that to this hour, in my nocturnal rambles, I sometimes keep a sharp lookout on suspicious places; and though nobody can be more skeptical than I am in such matters, yet it often takes an effort of philosophy to shake off these idle terrors."

Wordsworth evidently had a similar experience; for he speaks of

"Huge and mighty forms, that do not live

Like living men, moved slowly through the mind By day, and were a trouble to my dreams."

Barring accidents, children will not be more afraid of the dark than the daylight. It is probable that because people have pictured the darkness as inhabited by the strange and mysterious powers, against which the child can not protect itself when suggested, that they often show exception to this statement. In so far as accidental suggestions are likely to occur should we be on our guard against imparting fears of this kind. The "spooks" and the apparitions should be exor- 
cised from childhood land by a generation of careful and truthful teaching - a teaching which must not leave the darkness uninhabited to be peopled by any mischance with the "bogey" spirits; but which will instill the quiet confidence that "God dwelleth in the darkness as in the light," and His child may abide without fear or danger.

The romancing tendency of the child should be carefully discriminated in its moral character. It does not have the moral character of lying, although at times it may have that appearance. The child makes an imaginary world out of words as well as out of actions. It is not exceptional that this imaginative falsification may come forth in answer to questions, and the child seem in an effort to deceive. It may be paradoxical that there is such a normal activity as this in the child whose nature receives a dreadful shock at dishonesty in others. The key to the solution is that the two elements run side by side and are not to him consciously opposed to each other. The make-believe world is not a violation to truth in his own feeling. If parents will carefully make the distinction, it need not be so regarded by us, even when that made-up world has such a vivid possession of the mind that it is difficult to disentangle the fact. Our romance to children need not violate their nature; but a distinct misstatement of fact to them will destroy our influence ovèr them. Sir Oliver Lodge holds that children "should be told the exact truth when they" ask 
a serious question." A little boy put this contradiction of truth and romance in form one day, when he said, "What my mother says is so, even when it ain't so." I leave to others the solution of the Santa Claus problem, with this incident: A little fellow said at the recent Christmas, "I have found out about this Santa Claus business, and now I am going to find out about this Jesus business." Sydney Smith said that "he would a thousand times prefer that his child should die in the bloom of youth rather than it should live and learn to disbelieve."

Mrs. Lamoreaux calls attention to one of the dangers of misunderstanding this activity of the mind. She says: "This world of make-believe is as real to him as the world which is seen through his eyes, and often he can not distinguish between the two. Many a little heart has quivered over the punishment inflicted for 'lying,' when willful misrepresentation was not in his thoughts. However, harsh treatment of a vivid imagination may result in real deception later on; for the child can not help 'seeing things' too wonderful to be enjoyed alone, and then, perforce, there must be deliberate planning to escape the punishment.

"This harshness also begins to raise an invisible barrier between the child and the parent. It was felt by a little maiden of rare fancy, who said in a whisper at the conclusion of one of these marvelous tales, 'But don't tell mamma.' The impassable wall between many a mother and 
daughter in later years, once consisted of but a scattered stone here and there." ("The Unfolding Life," 66,67.) This activity should be cultivated by an active sympathy. It is one of the rich powers of the being. The constructive imaginative power will be needed in any vocation of life. To see things that are not yet is the essential element of the statesman, the merchant, the doctor, the preacher, the reformer, as well as the poet and the painter. That person is a more helpful parent or teacher who can become a child again and enter again into the world of makebelieve with the child. The literature of stories and heroes that assist this faculty is not only commendable, but essential to normal development at this time. Blessed the child who has a grandmother or grandfather who has passed out of the hard facts "that are seen" and has come again to the land of vision and will tell him the wonderful excursions made by fancy in that delightful world where all things are as we please to have them.

\section{Section IV. Later Childhood.}

In a very real sense each period prepares for the succeeding one. The problems connected with any period are partly solved by the good or bad foundation laid in the preceding one. The difficulties of Later Childhood, which extends from the seventh to the twelfth year, in any case 


\section{MORAL CONDITION OF THE CHILD}

great, are more easily mastered if wisdom has already guided the hand of the parent up to this point. We are always reaping what we have already sown. So emphatic is this truth that if a child's character-direction is now to be undertaken for the first time, it would be a bold prophet that would announce the probability of success. We will assume that there is simply to be the continuance of good work already begun. In this case there will be no sharp corner to be turned. The changes to be noted will not transpire some bright morning, making that day's task greatly different from what it was the day before. Nevertheless the changes are real, and one must be prepared for them and be able to discern at last when they have arrived, even though they have approached by imperceptible increments.

Former lines of activity still continue; some to be intensified; some to diminish gradually; others are introduced that are more or less new. Physically this is a period of slow growth, but the health is good and the vigor strong, excepting that at the age of eight or nine the child is easily fatigued. There is great increase in manual dexterity, and corresponding to it the sense of utility has grown. "What can you do with it?" "What 's it good for?" are frequent questions. There is an increase in objectivity of attitude as distinguished from the imaginativeness of the earlier period. Fact has more charm than fiction now. The child insists on reality. He will 
like a story better if in answer to his question we can insist that it is true. "The wise teacher will discard imaginative illustrations and use those drawn from history, biography, science, and his own experience." Doing rather than dreaming is his ideal.

Now, if not before, he spends much time out of doors. This tends to independence and spontaneity of movement as compared with the former imitativeness. This is attributable partly to the accidents of parental direction rather than to the disappearance of the tendency to imitate. There is plenty of action still, but it is not now the mere release of nervous energy; it is guided more by purpose and aim. The brain now attains its full human size, which may well suggest the entrance upon a new stage of life. Yet it is a period comparatively uninteresting to investigators and perhaps to people generally. Less is written about it than concerning Early Childhood on the one hand, and Adolescence on the other. The naïvete and "innocence" of childhood have passed; the earnestness of Adolescence has not arrived. The child from seven to twelve must for a time be content to be rather uninteresting and sit in the shadows little observed. This is probably less trying than at some other periods; for he does not readily express himself publicly. He is observing rather than being observed; often he prefers to do this from some seclusion where his presence is not noticed. An effort to make him 
express himself before others must likely be based on an appeal to his vanity and may be an injury rather than a benefit. He is now allowing impressions to sink down deep into his nature; after a while they will come to expression. Selfishness now asserts itself very strongly. Acquisitiveness is very active. These qualities make the use of rewards and punishments very effective, and for that very reason they may be misused unduly to accentuate these natural tendencies. It will take great tact to direct them toward good developments. Honor rolls, badges, buttons, grades, and rank are very influential. The feeling of justice is very strong; playing fair is a standard of great potency. Curiosity, heretofore a strong passion, is now regnant. It is now the time when a boy will shut himself up for half a day and take a clock to pieces to see how it is made. This passion for knowledge should be regarded as God's thirst implanted in the soul to be satisfied to the fullest. possible extent. It would be abortive to crush it; it is soul-growth to strengthen it. However, it may lead in any moral or immoral direction; the work of the good guide is to direct it in the interests of the higher and eternal life. Authority is now naturally acknowledged. Previously he may have followed inclination without any recognition of its contradiction to the will of another; now he recognizes the two wills and, if rightly directed, learns to submit his own without wrench or strain to his nature. The sense of right and 
wrong is stronger than it was formerly, but yet does not often prove a determinative power of decision. He still leans on the moral consciousness of others. This fact aids rather than hinders in rendering obedience to others.

The social instinct is now greatly strengthened. Its direction raises one of the most difficult problems yet encountered. $\mathrm{He}$ is still appreciative of companionship in general; but companionship of the same sex and age becomes imperative. The "gang" spirit now arises with all its indifference to every other question except companionship. This is a law of nature unrepealable; how shall it be dealt with? We assume that every natural law may be used in the higher development of the child. Some parents respond to this demand with no thought of directing it to the higher nature, and let the impulse have its wild way. The boy at least is turned loose to find his own "gang," and the problem of character is surrendered. The unresisting response to this wild demand is no more rational than it would have been to give way before the wild striving of any other natural impulse. The impulse means companionship. The problem is to provide such as will be helpful and not ruinous. Parents themselves may unbend and become children with their children, supplying at once the yearning of the child and gaining a stronger hold upon them. It is also the opportunity of re-enforcing the resources of the home from the best of the outside 
world. Such companions as would help in the character problem may be invited into the home. The companionship of life through literature is suggested by the need. Inquiry will open up a field of influence from this source that is almost compelling. As a matter of fact there is no child so difficult as the one that is seclusive, individual, unsocial. One can not steer a ship that is standing still. One can not guide a life that moves not. This social impulse is the great danger and the great opportunity. It is the period of hero-worship. This element may enable one to hold in check and direct other activities not so directly noble or easily controlled.

This is the period when the child starts to school. This event renders the problem very complex. Of our public school system we are justly proud as being, all things considered, the highest mark of our civilization. Our public school teachers rank far above the average of our people in intelligence and morals. To mention school life as intensifying the difficulties of child-culture above any one factor yet encountered, is not to speak slightingly of these. But the school neutralizes the distinctive features of the home to a considerable degree. It is a leveler. Into it go the influences of all the homes of the community, and some of them are careless and indifferent to a degree that renders the children from them a moral infection. These homes have none of the ideals for which we are pleading; crime and filth 
and moral shame have no opposition, but are yielded to under the slightest occasion. The children from such homes array their authority and influence against all the rules and standards of the homes that seek in the wisest way to develop virtue and high character. Your little seven-yearold is' to be submitted to this moral blast when you are not there to protect or to neutralize. Surely that presents conditions of an uncertain issue if not of an unfair struggle. It would lead us wide afield to discuss it, but the only means of combating that influence, apart from aiding the school teacher, is to join with others in the effort to uplift that degraded home. Its existence is a menace to your child as well as to the destiny of the child that comes from it. Under certain circumstances it might be duty to refuse to send your own child to the school if the danger were imminent and too great for a child to meet without almost certain destruction. The State has no more right to harbor a moral infection in the school than it has a physical one.

During this period, if ever, the church-going habit must be established. Differences of view might be encountered, and some reasonable, if not compelling, objections given for its neglect hitherto. But all subterfuges should now be swept aside. Those who believe that the Church has a mission, which can be accomplished only for those who attend its services, must now endeavor to establish a love for and a habit of Church attend- 
ance. Neglect up to this hour may have been a mistake; further neglect is fatal. The child that neglects church attendance up till twelve years of age, barring spiritual accidents, will join that large crowd from our Christian homes who never become Christians. The feeling of need of the Church is a childhood growth; if then suppressed, there is no natural period for its development.

There is no development of this period more burdened with destiny than that of the memory. Memory was an early activity, but it was not retentive. It was sufficient for the personalityformation of that passing time; but it did not bridge the years of childhood and maturity. The bonds of association in an infant's memory are like ropes of sand; unless continually rebuilt, they fall away. But our present period is the "Golden Memory Period." "The physical side of memory is most interesting. On the covering of the brain, each in its own place, the images or impression brought in by the senses and the activity are registered. So sensitive and so susceptible are the brain cells during childhood that these impressions are received as clay receives the touch of the sculptor's finger, and under right conditions they are ineffaceable. When the soul acts upon these images they live again, and we say, 'We remember.', (Mrs. Lamoreaux: "The Unfoläing Life," 69.)

So to speak, the brain cells are not preoccupied now, and they may. receive impressions which 
shall have right of way for all future life. It is the ideal time to store the mind with all kinds of mental wealth in literature-poetry, the Bible, hymns containing the best truths of life and spirit. And then, how important to store the memory from the life itself with impressions that will be mental wealth when recalled. Memory has to do with that strange something or nothing which we call time. It is a very elusive thing. We sometimes call it a stream; and yet future time is nonexistent; past time is non-existent; present time as soon as it exists becomes past time, and hence vanishes. Yet with this vanishing nothingness we build the most precious things of consciousness or destiny. The bridge that spans the present and the future from this end is called Life; from that end is called Memory. As life, it is short; as memory, it is long. Its pleasure as memory can only be determined by its character as life. Now we can arrange it for our child to be either pleasure or pain; then, it must be what it has been. The pleasures of memory depend not upon itself, but upon the nature of past deeds. It is impartial; it brings back all of the past, whether of joy or misery. The wealth of all after-years, through the channel of memory, is potentially in the hands of parents now. Cares will come after a while; sorrows will sink their pangs deep into the nature. What an opportunity now to sow deep the sunshine of life, that, come what will, can not be entirely effaced! 
Section V. In the Years That Follow.

We have now followed the child as far as our purpose requires. There yet remains the period of Adolescence; but it belongs rather to youth than to childhood. It has received much attention from investigators, and literature upon it is abundant. It presents opportunities for revolution of character, while we have traced only normal evolution.

If the proper attention has thus far been given to the child, he is now well prepared for entrance upon this peculiar "storm and stress" period. He will have unusual crises-physical, mental, and spiritual - through which he must pass, which will require the greatest attention and care from his spirit-guardians. But with a good foundation laid, there is every ground of expectation that these years will be safely passed, and the youth emerge into mature life with an equipment that is a guarantee of moral success.

The child, as we have followed him, is equipped at twelve years of age with a strong body, which is now about to enter upon a period of growth more rapid than he has ever before known. He has developed a moral sense which is a capable guide in situations where he must act alone and without consultation, as they become necessary. $\mathrm{He}$ has learned respect for and obedience to his earthly parents, and they have made themselves a symbol of the Heavenly Father, whom he has 
come to know through this means and the everpresent and ever-active influence of the Holy Spirit, who uses these symbols and teachings of earthly guardian-spirits to make known the invisible God and His purposes for men. We have no sure ground of confidence that the Holy Spirit performs this office in the absence of this human teaching. The spirit of obedience toward the parents has in it the elements and essential nature of yielding to the Higher Spirit, provided those parents have recognized their true office and relation to God and the child. The tastes of the character have been formed on a high plane and will not respond to appeals from lower levels. The feelings of the nature have been trained to be active in lines of sympathy and kindness. The control of the nature, both of the animal and rational, has been long disciplined and is now comparatively able. Virtuous habits have been formed which will steady him in trying hours when the spontaneous moral energy of the moment would not be sufficient. The child enters a world that is not "a friend to grace" indeed, where temptations are strong, and streams of social influence are against the ideals that have been implanted. But that world has no dominant ally within, although it will always seek an alliance with his animal nature. That physical nature, however, has also learned how to obey. It has been subjected to a strong control and to habits the bonds of which it can not of itself break. It can overcome only 


\section{MORAL CONDITION OF THE CHILD}

by some subjugation of the tastes and feelings, some tumultuous momentary onslaught, which may, indeed, secure a momentary victory; but even then through shame and contrition the usual and normal moral status may be re-established. Character has an inertia such that it does not radically and permanently change in a moment. This law is an impediment to sudden reformation; but it is also the bulwark of the virtuous against deformation.

That strange and unscientific factor called freedom of choice has not been nullified, and we therefore are unable to predict invariably what a soul will do. Some allowances have always to be made for this unpredictable element. Nevertheless there are laws of spirit-formation which we may investigate and whose working we may observe; on the outcome of these we may rely in the general results of life. The parent who has wisely obeyed these laws may confidently depend upon expected results, and in case of any temporary disappointment may with good conscience ask the special assistance of society and the Holy Spirit of God to confer unusual grace for what seems an unusual and humanly unavoidable result. 


\section{CHAPTER IX}

\section{THE MORAL SENSE}

I тнINк we must say that the religious nature of the child is neutral until the dawning of the sense of ought, or of the sense of right and wrong. Even then it is premature to think of him as a complete spiritual being. The time of the dawning of this moral sense is of very great interest and importance. Our reproaches and punishments must be adjusted to it. Stanley Hall says : "'For children all offenses are simply forbidden things, and the distinction between what is wrong or forbidden and what is criminal, and the perspective that differentiates between different crimes, comes late, but moral comes even later than intellectual maturity." ("Adolescence," I, 403.)

I know a little fellow who is sometimes caught doing what he has been forbidden to do. He is seventeen months old. When thus detected he will be found with his hands behind him, a picture of innocence. This presents a curious problem. Has he a conscience which he is disobeying? If not, why does he hide his action? I am inclined to answer: He has as yet no sense of right and wrong. His action, which seems so much like depravity, has in it no moral quality. The effort 
to hide his action grows out of the knowledge that it has been forbidden, and the doing of forbidden things is associated with punishment. Professor Major in his observation of his own child noted that the little fellow had many devices for getting away his little brother's playthings from him. It looked much like selfishness, but probably was not; for he was quite willing to let his brother have his own playthings. It was action which his opening powers suggested, that was not yet inhibited by the higher element, as yet undeveloped, of unselfish or altruistic action. His own testimony concerning the child at this age is, "I have never seen a single trait which even the "unembarrassed scientist' would call vicious." Some day there must come from within a feeling that it is wrong to do wrong. At about the age of six or seven years the child acquires the sense of the conventional, which is the idea of the proper or a social standard. This looks very much like the beginnings of the sense of ought as controlled by others, so far as we can trace it to outward influence. The conventional may easily pass into the obligatory. "With the beginnings of this consciousness the symbolic bent of the mind begins to yield a place to the higher and more conscious form of intellectual and moral activity." (W. T. Harris.) As to the nature and origin of conscience there is much difference of opinion among thoughtful writers. When one accepts the point of view of Divine Immanence, it is not so easy to distinguish the innate from the extra-personal. 
But speaking as a religionist, we love to think of it as God's voice and man's voice-God's voice in man's voice, and adopt the language of Kant. He says: "There are two things that fill my mind, the oftener and longer I dwell upon them, with ever-fresh and ever-growing admiration and awe: the starry heavens above me and the moral law within me. Neither is veiled in mystery or lost in immensity so that I need to seek them beyond the sphere of vision and merely surmise that they are there. I see them before me and link them immediately with the consciousness of my existence. . . . The second begins from my invisible self, my personality, and exhibits me in a world which has true infinity, but which is traceable only by, the understanding." (Eucken: "Problem of Human Life," 445.) Goethe must have had a similar faculty in mind when he speaks of that sentiment "which none brings with him into the world, but on which it entirely depends whether or not a man shall be in all respects a man-the sentiment of reverence." (do., 474.) But, however mysterious its origin or inexplicable its nature, the conscience never speaks more authoritatively than in the first years after its manifestation. W. E. Gladstone has told a beautiful story of it when it spoke to him as a stranger whom he did not recognize. It was when he was a little boy in his fourth year. He lifted a stick to kill a tortoise. "But all at once," he says, "something checked my arm, and at once a voice within me said, clear and loud, 'It is wrong.' I held 
my uplifted stick in wonder at the new emotionthe consciousness of an involuntary but inward restraint upon my actions-till the tortoise vanished from my sight. I hastened home and told the tale to my mother, and asked what it was that told me it was wrong. She wiped a tear from her eye with her apron and, taking me up in her arms, said: 'Some men call it conscience, but I prefer to call it the voice of God in the soul of man. If you listen and obey it, then it will speak clearer and clearer, and always guide you right; but if you turn a deaf ear or disobey, then. it will fade out little by little and leave you all in the dark without a guide. Your life depends upon this voice.' Then she went her way about her affairs, but no event of my life made a more deep and lasting impression upon me." This voice of God may at first speak only the things that are permitted; it may associate itself with the things that eause no pain; there may be primarily and even permanently some confusion, but its imperative is unmistakable; something in it will be heard above the din and clamor of earthly voices. Macbeth is not untrue to life when he asks :

Whence is that knocking?

How is 't with me when ever'y noise appalls me?

What hands are here? $\mathrm{Ha}$ ! they pluck out my eyes.

Will all great Neptune's ocean wash this blood

Clean from my hands? No; this my hand will rather The multitudinous seas incarnadine,

Making the green one red. (Macbeth, act ii, sc. 2.) 
It is thought by some that this moral faculty is an imitative function and has its origination in obedience. The child first feels the compulsion of command from his parents and from that gains the idea of obedience. This becomes a well-fixed attitude in his relation to them. But he will after awhile observe that they too are obedient. They sometimes say that they must do things or must not do things which they do not want to do or do want to do. In the parents the child notes-rather confusedly, of course, though more clearly when oft repeated-that the parents are obeying some unseen source of obligation. They say: We must; we must not. We ought; we ought not. An unseen authority is felt by them whom they obey. These instances of obligation come to be reduced to rule or principle, and after years the child has been impressed with a law of obligation that is different from the authority of his parents. It is very probable that this sense of moral obligation would be very seriously impaired where the parents act capriciously, always as they pleased, and were not themselves obedient to a Power not themselves.

Another root of this same origination is thus stated by Baldwin: "Suppose a boy who has once obeyed a command to let an apple alone, coming to confront the apple again when there is no one present to make him obey. There is his private, greedy, habitual self, eying the apple; there is also the spontaneously suggestible, accommodat- 
ing, imitating self over against it, mildly prompting him to do as his father said and let the apple alone; and there is-or would be, if the obedience had taught him no new thought of self-the quick victory of the former. But now a lesson has been learned. There arises a thought of one who obeys, who has no struggle in carrying out the behest of the father. This may be vague; his habit may be yet weak in the absence of persons and penalties, but it is there, however weak. And it is no longer the faint imitation of an obedient self which he does not understand. It carries within it, it is true, all the struggle of the first obedience, all the painful protests of the private greedy self, all the smoke of the earlier battlefield. But while he hesitates it is not now merely the balance of the old forces that makes him hesitate; it is the sense of the new, better, obedient self hovering before him. A few such fights, and he begins to grow accustomed to the presence of something in him which represents his father, mother, or in general the lawgiving personality." ("Social and Ethical Interpretations," 54.) The remaining step to be taken is to eject this representative of authority into all others of the family and all others generally.

This view of the origin of conscience may shock those who have regarded it as a purely extra-natural production. But it need not disturb our view that it is God's voice, however unsettling it may be to its sometimes supposed infallibility. 
We are apt to credit the doing of those things to God, the method of doing of which is hidden from our view. Then some day, when we look through a little glass and discover God in the doing of it, our first exclamation is, $\mathrm{O}$, it was not God, after all, who did it; it was somebody or something else! But this second thought is our blunder. God does it just the same when He puts a parent at the heart of the task, and through them accomplishes His purpose. May it exalt our view of parenthood when we see that they are vitally connected with this problem, and in their absence it is never well done; nor is it well done when they, careless of their task, do not recognize that they are in the place of God to their child.

What particular actions are wrong will be determined by the commandments from his parents until the time when he may have an understanding of the Higher Parent. Then His commandments will also be regarded as the content of moral conduct.*

The dawning of this spiritual sense is comparatively early, though no fixed age can be named that will hold for all children. Some children have it as early as four years; others as late as seven; others possibly later. If we should

* "Poor soul, here for so little, cast among so many hardships, filled with desires so incommensurate, and so inconsistent, savagely surrounded, savagely descended, irredeemably condemned to prey upon his fellows' lives; who should have blamed him had he been of a piece with his destiny? To touch the heart of his mystery, we find in him onc thought strange to the point of lunacy; the thought of duty; the thought of something owing to himself, to his neighbor, to his God; an idcal of decency to which he would rise, if it were possible; a limit of shame, below which if it were possible he will not stoap."--(R. L. Stevenson; "Pulvis et Lmbra," quoted by Tyler.) 


\section{MORAL CONDITION OF THE CHILD}

name six years, we would find it accompanied with marked physiological changes : it is the period of the second dentition; the brain has achieved its adult size and weight; now is the time of reduced growth, and increased activity and power to resist both disease and fatigue. (Hall: "Adolescence," II, 451.) There is no other such marked year between the third year and puberty.

J. R. Street, of Clark University, conducted an examination of one hundred and eighty-three persons, from which he drew the conclusion: "There was nothing to show that conscience played any great factor in life before the age of nine, and very little mention was made of it before thirteen. The cases, however, are altogether too few to make any generalized conclusion concerning the age at which conscience becomes a potent element in the individual. Yet it may be premised that it does not reveal its existence at as early an age as many would believe. The writer knows a child in whom it was abnormally developed at the age of three. Impulse governs most of the activities of early childhood." (A. MacDonald: "Experimental Child Study," 1339.)

When we reflect that brain cells are not sufficiently formed for purposes of intellectuality until about the sixth year, and that conscience should follow reflection, we must not expect conscience to be a factor before that age, and then only in its germinal form. As to what things a child's 
conscience shall say, we must know what has been taught by its parents and teachers.

MacDonald calls attention to another important point when he says: "Moral training is not the establishment of mere moral habits, as the ethical people advocate, but is the unfolding and widening of the deeper instincts, particularly the emotions, and has its roots in the religious sentiments that so early pervade child-life. . . The parent stands in such relation to the child as to enable him to seize upon the deed germ and so to nourish it that it will produce the beautiful plant of a pure, noble character."

This conception of the conscience assumes (1) a primal instinct that may be unfolded in childhood. This is not a moral endowment, implying merit or demerit, but an endowment of the nature, which when exercised opens in moral character. (2) The control of the action of the child directs the unfolding instinct or emotional power to the good or the evil character. The conscience faculty may have no content, but it does have a certain texture which forms a basis of moral reaction from the influences which shall come upon it after a while.

The important point is: not that we should adopt some time for the application of a religious formula and judgment concerning its spiritual relation to God, but that we should regard the moral awakening, whenever it comes, as a phe- 


\section{MORAL CONDITION OF THE CHILD}

nomenon realized and treat the child accordingly. Just as we observe the awakening of self-consciousness and the faculty of reasoning, so we should observe the awakening of the moral faculty and seek at that point to have it choose righteousness as such. That choice for the child is tantamount to the choosing of God. It has all the significance for the spiritual relation to God for the child that conversion has in riper years for the adult. I do not mean to say that a child can at that time make a choice that carries it unchangingly into the future, as the adult may. The child's nature requires that this choice be confirmed by every succeeding choice. But the choice for the moment contains the child's religious relation for the moment. If that choice is confirmed ever afterwards, the child is an acceptable child of God; if a contrary choice is subsequently made, it will need to seek forgiveness, just as the adult does when he falls from grace. This moral condition has the childish element of instability; but it has no taint of sin upon it. The instability suggests the child's moral dependence upon parents and teachers. It can not live its moral life alone any more than it can live its physical life alone. The parent is the child's moral supplement. 


\section{CHAPTER X}

THE SCIENTIFIC ERA OF RELIGIOUS INSTRUCTION

THERE are other elements than the dawn of the moral sense that enter into the question, When is the ideal time for religious instruction? The period for the formation of habits is from the third to the seventh year. Character, from one point of view, is the by-product of actions, and habitual actions thus are of most intense importance. Perhaps it was from some such knowledge as this that caused that student of this question, the most profound yet produced in America, Horace Bushnell, to say that more could be done to make or mar the eternal destiny of a child before three years of age than could be done afterwards. Remembering, then, the importance of these early years, and then from six years on to thirteen or fourteen, we have the period of opportunity for parent or teacher to lead a soul to Christ. After sixteen we may compare their rescue to that of the passengers wrecked in the ocean, clinging to planks and timbers. Some of them will be picked up; but it all seems accidental, and no rule can be named as to how it may be accomplished. There probably always has been in the 
Roman Catholic Church a scientific basis for the teaching of religion. Our objection to that Church can not be so much because of their methods of instruction as to the subject matter of their teaching. In method they are able to teach us very much. Their adherents, even without the strong religious passion that a personal yielding to Christ gives, are very tenacious to the faith and practices of their Church.

The evangelistic method can not be called scientific; nor can it be called ideal. It is greatly to be commended as a method to be used with adults who have lost their opportunity of scientific instruction. But its continuance under present conditions is losing to the Protestant Church twothirds of its children, and presents the most alarming and discouraging view of Christianity in the world. The greatest discouragement that we face is not in China, with its unknown number of millions to be evangelized, indoctrinated, and converted; but rather the fact that here in America from our Christian homes and Sunday schools sixty per cent of our children never become Christian. When we look at the means necessary to hold them, the neglect that we observe is as significant as the result which we deplore. They are not receiving the instruction, during this ideal period when they might be won, which is in any degree sufficient to insure that they will become Christians. They are allowed first to be lost, and then, when character's choice has been 
made, a belated and necessarily ineffectual effort is made to win them back.

Says Dr. David G. Downey: "The child holds the future, and the only way to save the future is to save the child. We can not save the child by allowing him to go to the devil in his youthhood, and then attempt by special and spectacular methods to win him back to God in his manhood. Our method of approach to the child-heart and mind must be in harmony with the well-established laws and principles that govern the child's growth. Religious development must be made not a matter of miracle and magic, but a part of the child's normal development, just as natural and normal as his development physically or mentally. God has ordained a right time and a right way for developing a child's physical life. It is not a matter of chance, caprice, or magic. It is a matter of care, feeding, exercise, and environment. Every parent understands, and up to the measure of his understanding co-operates with the divine law. God also has ordained a right time and a right way for developing the child's mental life. It is not a matter of chance, caprice, or magic. It is simply a matter of instruction, guidance, and teaching at the right time. Every parent and every teacher understands, and as far as possible co-operates with the divine law. . . . Let that time pass unimproved, and the child is intellectually lost. . . . Has God ordained a right time and a right way 
for developing the child's physical life? for developing the child's mental life? and has left his spiritual life without plan or care-a matter of chance, caprice, magic, miracle, or whim? Assuredly not. Here as elsewhere, nay, more, just here especially God has a right time and a right way."

It is probably not sufficiently realized that youth is the great crime-producing period. The County Court of Kings, New York, for the year 1908 passed sentence on 950 persons convicted of crime. Of these 491 were under twenty years of age and 283 were between twenty-one and thirty, and only 176 were above thirty years of age. In New York State in one year the superintendent of instruction reported 179,000 arrests of children under fifteen years of age. In France it is noted that during recent years juvenile depravity and criminality have greatly increased. They have passed a law that recognizes that every criminal under eighteen is still a child, and as such unfit for prison. Houses of correction are established, the distinguishing feature of which is, as far as possible to keep those convicted in touch with the home, recognizing it as containing the only sufficient elements for character formation. "Possessing as they do the ear, the heart, and the sympathy of the child, parents have it within their power to develop the child into almost whatever they may wish. Hence if they would get back to the Hebrew conception of the family, and would 
devote themselves as diligently to the nurture of their children as they do now to the ways of fashionable and business life or, better still, with all the solicitousness that they exercise in the rearing of their horses and dogs, the problem of the moral regeneration of the race would be most thoroughly solved." (MacDonald, 1342.)

A religious curriculum, embracing morning and evening prayer, attendance upon Sunday school and Church, and daily instruction in the religious life, would not be too much to withstand the tides of opposition to Christianity flowing all about them in our land. It is probable that modern times present many more allurements away from the Christian life than did several centuries ago. Yet we are far from equaling some of the Christians of those more simple times. The spiritual descendants of John Huss showed a carefulness and zeal which is not found in modern Church customs. The important connection between the Church and the home was thoroughly recognized. The membership of the congregation was divided into three sections : the beginners, the advanced, and the perfected. The first section was the children, who received separate instruction in the Bible. The instruction received in the Church was supplementary to and a review of that which was carried on in the home. Officers of the Church visited the homes regularly to see that the plan of home instruction was carried out, and reported the conditions to the pastor. "This 


\section{MORAL CONDITION OF THE CHILD}

home training consisted in a personal examination of the children by the father, usually during or after the midday meal, to discover what they remembered, and how much they understood of the religious teaching they had received, either at school or any of the many services of the week. From very few of the Church services were the children excused. . . Morning and evening family devotions were also conscientiously kept up." Several services were held during the Sabbath; one of them might overrun an hour, but the afternoon and evening services were scrupulously held to thirty minutes. During special seasons of the year the lessons suggested by them were carefully and impressively taught. During the year the whole Bible was gone over in outline. The parochial schools, which were held during the week, also made the teaching of the religious and moral life of great prominence. In view of this careful training of the children we are better able to understand the profound impressions that the Moravians have made upon the world.

Moreover, an indispensable condition is that children should not be associated with vice during these early years. No cost is too great that they may be shielded during those years when nature formed them to imitate what they see. It must be frankly admitted that this world is ill-adapted for the moral or even the mental education of the child. What are the sights that meet his eye as he goes to and from school? The great posters 
on the walls and the billboards sportray a world that he is not fitted to enter. Evil persons of adult years will try to engage his attention and his interest in their evil world. Children of his own years from the homes and slums of vice enact a life on the street that is very suggestive to his open mind. What comes to him from the newspaper that enters every home? Certainly very little that is fitted for his eyes and thoughtpictures and stories of crime and sin. The comic supplement to the Sunday newspaper is his especial enemy. It is gotten up to eatch his eye and engage his attention, but under the guidance of no moral purpose. One writer has recently said of. it: "It glorifies the smart child, proficient in monkey tricks; the cheeky, disrespectful, and irreverent child, who 'guys' his elders and betters; the libertine child, of silly, humoring parents." From the moral and religious point of view our modern world is very unfriendly to the child. He has no defenses in himself. He knows not his danger. Ofttimes parents do not comprehend that they are purposed to be his defense against moral invasion as really as they are against the invasion of physical danger and want. Many who pride themselves on the physical provision which they make for their children, allow them to suffer the merciless moral treatment of all the sin-traps of the street and public life that surges around our homes, seeking for entrance. In how many instances are tender chil- 


\section{MORAL CONDITION OF THE CHILD}

dren turned into the street to be the easy victims of its vice unavoidably visible! How many homes provide the instruction that we have noted as the minimum of necessity? Certainly the percentage of cases where these conditions are found is not as large as the percentage of children who become Christian. Many a child in a nominally Christian home has never heard his father's or his mother's voice in prayer. One of the most precious memories and most potent influences on life is thus lost. God is better to us than our plans and work. Those homes which carefully train their children with this daily and painstaking instruction secure the Christian character of their children; but those which depend upon their conversion through the agency of evangelistic methods are losing them in large masses. 


\section{CHAPTER XI}

\section{CHILDREN'S BAPTISM}

CHURCH history hardly affords a more striking illustration of the conflict between an instinctive spiritual tendency and the barriers erected by groping theologians than the manner in which the baptism of children has been treated by the Christian world. The New Testament is silent concerning it, and yet the teaching of Jesus has been arrayed on both sides of the conflict. The statement of John 3:5, "Except one be born of water and the Spirit, he can not see the Kingdom of God," seemed to shut children out of the Kingdom, their original sinfulness having been assumed. On the other hand, the statement, "of such is the Kingdom of heaven," was in direct opposition to this. Its plain meaning could not be evaded; but it could be neglected by those who could not make it harmonize with their belief. For the most part the Church has accepted both statements and emphasized both in the most inharmonious fashion. The custom of children's baptism probably had its roots in Jewish traditions and practices, and the fear that unbaptized persons would be excluded from the Kingdom for- 


\section{MORAL CONDITION OF THE CHILD}

ever, in harmony with the well-nigh unchallenged phrase, extra ecclesiam nulla salus. It grew early and extensively in the early Church, and at times has held an almost universal sway.

It has always been met, however, by two or more beliefs that seemed to make it untenable. The first was that baptism is for the "remission of sins." If this sin was original sin, of course it was logical for the child to be baptized as early as possible; but if it were for the sins actually committed by us, then it was best to defer baptism to a period as late in life as possible. Or if it were for both original and actual sins, as many held, the latter position is inevitable. This latter course was recommended by many and was the one pursued by Constantine the Great. Moreover, it was regarded peculiarly sacrilegious for a baptized person to commit sin, while an unbaptized person was privileged in sin. Augustin quotes the current saying, "Let him alone, let him do as he likes, for he is yet unbaptized." ("Confessions," I, xi.) The other belief was that baptism was a sign of admission into the Kingdom, which could be entered by those only who personally by faith accepted Jesus Christ. As this faith is impossible to children, they could not enter, and logic would require that they should be refused baptism, the initiatory rite. This attitude toward the subject has played a much larger rôle than the other, and is a very prevalent obstacle to the custom even to this day. It has been 
met in the history of the subject by the assertion of a sort of vicarious faith, or of unconscious faith on the part of the child. On the one hand, those who were sponsors for the child, parents or god-parents, were supposed to be able to exercise a faith that was available for him. On the other hand, some supposed that a sort of unconscious faith was exercised by the child. Thus Calvin taught, "Infants may have infused into them a kind of faith and knowledge, though not ours." This, however, as has been pointed out by Harnack, was an abandonment of the Protestant view of faith, and has not exercised so very. great influence on the practice.

The High Church idea of baptism, which may be called baptismal regeneration, has had a very great part in the defense of this custom. It is in the realm of the mystical, if not the magical, the mysterious, approaching the superstitious, if it does not actually reach it. It tries to escape the charge of mechanism in spiritual things, that the sheer application of water in itself works the regeneration of the spiritual being. I will not attempt to state the form of this disclaimer, for to me it has no validity. To its defenders the modus operandi becomes a matter of great importance. It must be the application of water, and not some other liquid, as milk or wine. Great care must be exercised that it be not repeated. If in doubt about this, one must preface the administration by the phrase, "If thou hast not 
been baptized." As the ordinance works of itself, it is valid even though it may have been performed by a heretic, etc., etc. Innocent III held that, as sin came to infants without their consciousness, so they could be freed from it by the power of the sacrament. In accordance with this line of reasoning, he thought that baptism would be effective upon men asleep or mad, if they had previously expressed a purpose of receiving it. (Vid. Hastings : "Encyc. of Religion and Ethics," II, 398.)

The Council of Trent, building its doctrine upon the tenet of Original Sin, made one distinction of value; though this distinction, so far as I know, has never been developed into a clearer expression of the normal human condition in morals. Its teaching is thus represented: "The guilt of original sin is removed in baptism, and the regenerate are no longer sinful in the eyes of God, though there remains in them a root of concupiscence, which is left for them to struggle against. This concupiscence must not be called ' $\sin$ ' if by the term it is implied that there is anything in the regenerate which can properly be called sin. It is sin only in so far as it comes from sin and leads to sin." (do., 399.) This point, that sin remained after baptism, which was supposed to remove it, had caused much trouble. Some were bold enough logicians to simply reject the fact. Augustin held that baptism "means the breaking down of the sinful habit, the be- 
stowal of a special grace of resistance, but not the entire removal of the enemy." Hillary had to warn his readers against supposing that baptism would restore them to the innocence of childhood. Baptism in the second century was regarded as a peculiarly strong form of exorcism. "Just as the Red Sea drowned Pharaoh, so baptism drowns the devil out of a man."

In general all these teachers and Churches, which taught infant baptism, regarded confirmation, or some other step to be taken when the child came to years of responsibility, as a necessity, which in effect is a substitute for believers' baptism.

It is little wonder that a custom that has been defended by an appeal to such absurdities and unfounded necessities, by such conflicting arguments and disregard of personal history, should fail of general acceptance and understanding, and be assailed with such sarcasm as this custom has met. And yet Christianity would be of little value if these attacks upon the custom were invincible. If Christianity is not for the child, then one-half of the human race are cut off from its benefits at a stroke: for one-half never grow up to be adults. But this is not the worst aspect of this opposition; it will have only a disputed value for the other half. If Christianity is not for the child, it is hardly adjustable to normal humanity, and will ever remain a little "lean-to" to life, the worth-while-ness of which will be dubious. If 
Christianity is normal to human life, it must cover the whole of it, and especially that part in which character is formed. If the child can come to a normal human spiritual stature without the help of the Church, the acceptance of Christ by the adult is emphatically superfluous. But to admit that the child may receive the benefits of Christianity, and yet refuse it the ministry of this rite, universally regarded as initiatory, is an indefensible position. How can it run the course, if it never enters upon it? We would place the baptism of children in a central position, and at the same time divorce it from the mystical, irrational, unrealizable ministrations that have been claimed for it. Its benefits in plain sight are sufficient to bind it upon us with indissoluble bands. With the cancellation of the doctrine of hereditary sin we at a stroke get rid of a mass of contradictions and absurdities. However the phrase, "for the remission of sins," may be interpreted, it creates more difficulties than it dissolves to say it is either for the sins which we inherit from Adam or, so far as it is a physical act, that it has the least effect in washing away actual sins. Biblical interpretation is never justified in creating more difficulties than it finds. If Biblical phrase is so mysterious that we can not penetrate its meaning, let it remain a mystery; but let there be no obligation created by the exegete that compels a believer to accept what he knows can not be true without the destruction of fundamental principles 
in morals, and intellectual dishonesty or suicide. There are certain conceptions of infant baptism that appear to us as little better than gross superstition on the one hand, or based on imaginary necessities on the other. They dwell in the region of mystical relations and imaginary benefits. It is impossible to trace the moral benefit to children, as supposed, in their actual life. The announcement of these views has doubtless done much to discredit the true benefits of baptism. Some speak of the good children derive from it as coming to them under the influence of a covenant. For myself, I can not see that the idea, which seems to bind some formal obligation on to God, adds much to the notion of His universal love for all His creatures. Furthermore, omitting the idea of their inherent sinfulness, and there seems to be no barrier to be overcome by a compact to the full display of His love and fellowship. But to those who seem to see some force in it I would quote the words of F. D. Maurice. "I am deeply persuaded," he says, "that a covenant presupposes an actual relation; and therefore object wholly to those phrases which speak of the relation as if it were constituted by the covenant." ("Life," I, 209.)

The Anabaptists of the sixteenth century "instead of infant baptism had a ceremony in which children were consecrated to God." (Lindsay: "Reformation," II, 435.) This seems to us to secure the central idea quite effectively, while it 
betrays a needless reservation of the ordinance, as if it had some ulterior benefits. Baptism of infants can mean only two things: First, a recognition on the part of others of the right of the child in the Church. No spiritual benefit can come to it directly from the physical act of applying water, whether in this form or that. The custom of baptizing a child which is about to die is comparable to the heathen idea of salvation by some utterly non-moral influence. But so long as baptism is regarded as a rite of entrance into the Church it should not be denied to children. From the beginning they are in the invisible Church, and the visible Church is making good her claims to a vital work in the world when she undertakes with all zeal to have all whom Christ receives enter by some visible ordinance into her fold.

But in the second place, there are some benefits to the child of a more dynamic character. They are none the less because they are indirect. The baptism of the child is an act of the parents by which they acknowledge the divine relation of the child to God already established, the divine origin of the child, the divine ownership of the child, and the obligation laid upon them of securing to him a divine destiny. The benefits that come to him are from the vividness and vitality of these impressions upon the minds of the parents. Should they be lacking entirely, and baptism be given through the influence of some ficti- 
tious ecclesiastical valuation, the benefit will be nothing. But if these convictions are present in active form, then the child will each day receive the benefit of that consecration which gave it back to God and which abides in the ever-working vision that this is a holy child and may not be dealt with as if it were in the sole power of the parents to do with as pleasure or caprice or unholy ambition dictate. Where this consecration is lacking, the ordinance is an empty and meaningless form; its only effect is to work a delusion.

Children's baptism, then, demands certain conditions, without which it is only an empty superstition. If the parents understand its nature and its limitations; if they will undertake to carry out its implications ; if they comprehend that its spiritual working is vicarious, coming to the child through them, then its observance will be fraught with the largest possible blessing and spiritual fruitage. It is but the first act of a program of spiritual education and influence that, through a wonderful and divine arrangement, enables the parents to be in very deed the father and the mother of the spiritual form of the child, and not merely the cause of its physical structure. This assumes a previous instruction and preparation that probably are not usually given, but without which it will be as profitless and mocking as it is sacrilegious. Could this be adequately understood we would enter upon a period which would 


\section{MORAL CONDITION OF THE CHILD}

not, as now, lose to us seventy-five per cent of our boys and a large per cent of our girls into the non-religious life. According to our use of it will this practice be the most effective or the most useless religious instrument of all the ordinances of the Church. 


\section{CHAPTER XII}

\section{HOW CAN A CHILD BE SAVED?}

Some years ago the writer was attending a preachers' meeting in a Western city. The popular pastor of the largest Church in the city came into the room just as some brother was announcing with great confidence the opinion that no one could get into the Kingdom of God, or get to heaven, without being converted. Our friend heard the statement, and as he swung into his seat, called out, "That 's my sentiment." The discussion drifted on for half an hour, and then this pastor arose, very subdued, and said with much feeling that he had lost two children some years before, and he always thought that they had gone to heaven. "But if what is said here to-day be true, then I do not know where they have gone." This seemed to put a new face on the matter. If conversion is the only door that admits people to heaven, then only those who can exercise personal faith in Jesus Christ can be saved. The question is not so serious in regard to those who live to mature years and have the chance of complying with the conditions admitting to conversion. But it was formerly said that one- 


\section{MORAL CONDITION OF THE CHILD}

half the human race die before they attain seven years, and these are by their situation shut out from heaven forever, unless a future probation is provided for them, which last supposition is generally unacceptable to those who stand for the doctrine of conversion. Some try to relieve the situation to a degree by indicating that children may be converted when very young, suggesting cases of conversion even at four years of age. The Rev. E. P. Hammond, recently translated, gives a number of instances of children converted when four years of age, and one at the extremely early age of two and a half. If these cases could be multiplied manifold there would still remain a great question in our minds concerning those not thus reached.

Many inquiries arise in our minds concerning this question of child-conversion. They have such life-interest to us all that no one will feel like speaking lightly of the solution that another may present. Psychologists have serious misgivings concerning the procedure of these early conversions. They seem to violate the very nature of the child-mind. How can there be the consciousness of sin which is involved in the process? That the sense of sorrow may be brought about by suggestion and sympathy is well known. May there not be something artificial about the whole procedure? That many children thus begin their religious life is undoubted. One is tempted to say, Better this method, even if involved in mis- 
taken suppositions, than the inattention to their religious life which widely prevails. But while we refrain from denunciation of what may be a mistake, may we not inquire, Is there not a better way, based upon truer psychology and purer doctrine?

That better way for the child that lives to grow up, we will consider when we come to speak of the "Birth from Above." But what shall we say concerning those who do not live to grow up?

One of the answers is, Baptize them: this will cure the sin of their nature and admit them into heaven. We have already paid our respects to that teaching. It is a belated doctrine proceeding out of the night of superstition. We need add no more.*

Another answer is: God cuts short the work in righteousness; sanctifies them, and takes them to heaven. We confess ourselves unable to put any meaning into these words. Can it mean that God accelerates the mental and moral develop-

- The following is from a sermon preached apparently only thirteen years ago, published in the Homiletic Review. I will not name the preacher, but it will show that I have not misstated the position that was held by orthodox preachers no longer ago than that. To my ear it sounds from very far away. I do not remember to have heard anything like it recently.

"By nature they (children) are in Adam, and not in Christ; they are the children of the world, and not of God. It is a divine transaction (by which they are made partakers of life)-a new lifc is given in holy baptism. That which is born of the flesh must be 'born again of water and the Spirit.' What has been promised to parents and their seed by the Holy Ghost shall be actually conferred. It is called the "washing of regeneration.' With this infants have no more to do than with their natural generation. That is an act of God in His own appointed way, and the life thus commenced underlies and precedes all consciousness, all thought, faith, hope, and charity. Children may regain in Jesus Christ all they lost in Adam. Those who are baptized into Christ have put on Christ, and if afterwards they change their relation to God it must be by departing from Him." 
ment of these children, so that they can enter upon conditions of faith and acceptance of Christ, and that, this being accomplished, their nature is regenerated and they are taken into heaven? These seem to be the necessities of the case on the assumption of inherited sinfulness. We undertake to say that even God can not do that. Moral character is a personal achievement, and can not be thus cut short, nor any short cuts taken in its attainment. Moreover, the whole representation is the promulgation of a theory in dire distress. It is much easier to disbelieve the whole theory, to start with, than to stretch our credulity to such limits. Reject the doctrine of original sin, and it serves no useful purpose.

The answer that these children are sent to perdition, having never done evil, requires nothing but a reference to it. There was a day when it required argument; but the sun of that day will never rise again. It passes our comprehension that such an article of faith ever could have had an hour's lodgment in human belief. That man could ever have thought so vilely of God is a mystery which can never be fully explained. That belief has been driven forth, not so much by argument or presentation of proof texts as by direct insight. Whatever else is true, that can not be true. We may forever despair of an answer to our question; but this answer is forever barred.

The only other answer that can be presented on the assumption of hereditary $\sin$ is the answer 
of a Future Probation. The argument runs something like this: None can be saved except those who personally accept Jesus Christ as their Savior. Children and some others can not accept Jesus Christ here; therefore an opportunity will be presented for them to accept Him in a future world. They will remain in the Intermediate State until they have passed through the moral conditions which are denied to them here.

This doctrine, on the assumption of original sin, always seemed to me, since I first came in contact with it, exceedingly reasonable. I never was a convert to it, because I concluded that, while it seemed unobjectionable from its relation to children, yet there is not enough data to pronounce it proven. But from our point of view it is not a necessary solution.

Our own solution of the problem may be presented in a few words: Children are in an acceptable relation to God when they come into the world. That relation they can not annul until they come to years of moral accountability and rebel against Him. In the meantime, if He should take them to Himself, we have only the problem of their development in righteousness under an environment more favorable than here. That problem lies outside our investigation; we need not enter upon its discussion. 


\section{CHAPTER XIII}

\section{THE BIRTH FROM ABOVE}

We have no doubt of the spiritual birth that comes in a moment of time. We have no word of discouragement for those who are seeking to secure the instantaneous conversion of adults from sin to holiness. Let that problem be considered and advanced as much as possible by those who have responsibility for it. All we need to say just now is that the workings of the Holy Spirit are not confined to it, and that manifestly it does not apply to infants and children. The unconscious birth from above as experienced by children is scarcely in need of defense; it has been experienced by so many eminent Christians. G. Campbell Morgan "can not recall any definite time of his conversion. He believes that the gift of grace may be unconsciously received, especially by children who have been taught from earliest years that they belong to Christ." Another writer, a profound student of this question, says: "To one who has handled the material of these psychological studies it becomes very clear that at the conclusion of the adolescent period, or shortly after, no important difference can be discovered 
between the persons who experienced a conscious conversion and those who have simply kept up their religious growth. More than that, it is certain that the process of growth is in many cases simply a gradual way of going through the same change that comes to others in what is called conversion, and there does not appear to be any special disadvantage in the gradual process as compared with the process of rapid upheaval." (Geo. A. Coe.)

On the other hand, we can not go with those who represent conversion as a mere adolescent experience. If it were so, all youth would pass through it, and it would eventuate in the Christian life. It is capable of demonstration that of many of those who are converted the experience occurs in adolescent years; but a majority of adolescent experiences do not result in conversion. The larger number of youth do not take the road at that time which is described by conversion, but turn from it into the rejection of the religious life. To criticise the methods of religious workers by which they seek to secure the consent of youth to live the religious life, by assuming that they were unnecessary, and that these youth would have arrived there by the adolescent route, is to fly in the face of abundant facts. The assumption that nature would bring about the goal is far from being warranted.

We are of those who believe that the birth from above is not the mere naturalistic development 


\section{MORAL CONDITION OF THE CHILD}

of something in the personality of the child; but we also believe that the ideal work of the Holy Spirit is done for the human spirit in normal development of the spirit of the child; that children may from birth be the children of the Heavenly Father. Our present task is to inquire into the manner and methods of the Holy Spirit in such a case, that by co-operation with that Spirit we may learn to promote in increasing measure that muchto-be-desired end.

Our conception is well described by the phrase "birth from above." The manner of it is not that of an instantaneous moral change, which evidently does not fit the childhood condition, but rather a spiritual incoming from a pressure as continuous as that of the atmosphere about us. The birth of the human spirit we have already pictured as occurring during the years when the child is coming to human manifestation. Even though to some that picture may be unacceptable as to the birth of the human spirit, it may stand as our illustration of the incoming of the Divine Spirit. We hold that the Holy Spirit is an everpresent, ever-active influence upon the childnature. It must be admitted that divine methods in general are from germinal beginnings through unobservable increments to fullness of life. That it should be so in this spiritual birth from above should create no surprise. We can conceive a great deal being done for the child before there is a volitional response from it. Psychologists 
recognize the change in consciousness when there is no consciousness of change. Along with the development of the mental and conscious life there may be a development of the moral nature giving a very decidedly different spiritual condition in the child before there has been anything like a choice based on the knowledge of right and wrong.

Says Mrs. Lamoreaux: "The nurture of these years is as silent as that of the dewdrop upon the blade of grass, but it is as real. God's voice is the still small voice that ever speaks in quietness. The stillness of the moment at the mother's knee, the prayer repeated in the reverent, low tone of the mother's voice, the earnest prayer offered for him in His presence, the Christlike living in the home, all carry their holy influence to his soul. He feels God without knowing Him." ("The Unfolding Life," 40.)

The first moral relation of the child that is established is a relation with the parent. The child is obedient or disobedient to the parent long before he knows his moral relation to the Heavenly Parent. Right training will put into this relation with the parent the germ up from which will grow the moral nature in his relation to all other beings. Thus the parents in the beginning are in the relation of God to the child, and through relation to them the moral nature is to have its first exercise and training. We would then say, hoping not to be understood as saying more than we do saymore than should be claimed at this stage of the 
child's life-that the child that is obedient to his parents, thus fulfilling the highest that he can at that time know, is born from above, is a child of God. This yielding to God by proxy is all that can be expected of him until he has learned about God and His relations. I do not mean by that merely until he has learned to repeat by rote certain definitions from the catechism or elsewherewhich teaching I most earnestly commend; but which for the time may be to him but little more than so many words-but until that time when his comprehension is intelligent and real. Doing the right and seeking the good is tantamount in his stage of development to yielding himself to God and seeking Him.

Accepting God for him must be as the dawning day; as gradually as the conception is formed, so gradually must be its response. We can not definitely fix the first moment of the first ray, and it would not be of supreme significance if we could; for the increment of light received the succeeding moment is of as much relative importance as the first dawn. Each succeeding increment of Godconsciousness also has its importance. "And if one says, But there must be a time of distinct choice between God and the world, the answer would be that at best this only fixes the beginning of self-consciousness in religion, and not the beginning of religion itself. And indeed, self-consciousness can rarely be thus accurately dated; but religion in the properly trained Christian 
child has complex and untraceable beginnings in the spirit and atmosphere of the home, in childhood prayers, in participation in religious rites and customs, in imitations of those about him, in wise parental instruction and discipline, and in the hidden influence of the Holy Spirit. These things can not be dated." (Bowne: "Studies in Christianity," 269.) A very remarkable case of this in the concrete is that of Phillips Brooks. He had felt the call to preach and went to talk to his pastor about the preliminaries. His pastor remarked that it was usual to be converted before beginning to preach. Brooks replied that he knew nothing about conversion. ("Life and Letters," I, 142.)

We are assuming that all this time the child is in a relation such as is technically defined as the justified relation to God. This relation may be broken in his case, as it is in the case of the adult by disobedience to its standard of right. That broken relation may be re-established by contrition, as also in the case of the adult. Here, again, the parent fulfills his function by teaching the child the place of repentance. These missteps and restorations have in them more of the nature of the sorrow and restoration as experienced by the adult Christian than of the breaking off of the wicked life by the adult sinner in conversion.

The means of developing this God-consciousness is of importance to note. In his early years the child is a creature of imitation and subject to 


\section{MORAL CONDITION OF THE CHILD}

authority. He forms habits which at first are without moral content, but which become in later years the very means of selfhood. Hence the child should now be taught the habit of prayer. It is a great opportunity now to teach him a certain formula of words, the deep moral meaning of which he can not immediately comprehend; but as their meaning grows in his understanding, their moral force comes home to his life. He can now form the habit of Church attendance, which by its very inertia may carry him subsequently through many an hour of indifference. The habitforming period will not return again.

Some people, not comprehending the nature of the child, and reasoning from the nature of an adult, are fearful that harm is being done him by having to go through actions and word-formulas which he does not mean, because he does not comprehend them. This is an idle fear. Educators assure us that use or action always goes before the comprehension of the reasons for them. "In its application to moral education this law means that the habit of good conduct should precede ethical reasoning, that the child's activities, in harmony with the best, should be developed before he can understand ethical principles." (Griggs: "Moral Education," 75.) A child should pray before he can understand the relation of God to man. All the religious activities may precede the comprehension of the reason for them. It is desirable that the Church service should become fa- 
miliar to the child before he can comprehend the Biblical history from which the principles of worship proceed. The child is incapable of hypocrisy for the very reason that he can not comprehend; e. g., teaching a child the Apostles' Creed. He can not know the meaning of those statements of belief; is he, therefore, consciously lying in repeating them? By no manner of means. This is a mere formula of sounds; but those sounds will be imbedded in memory and will say themselves. back to him as the years go by. As the meaning of the words gradually dawn they will be accepted or rejected in the light of all other Christian teaching. Below the moral consciousness impressions and habits are being formed that will deeply grip the spirit in the coming years. Our own convictions of the truth of our teaching is our warrant for it. He who is without deep convictions will have no foundation to impress these truths on the consciousness of his child.

Our conception of the work of the Holy Spirit is that of the near rather than the far; of the normal rather than the abnormal and unusual; of the gradual and developing pari passu with the physical and mental nature rather than the instantaneous and the revolutionary. It fortifies the nature before habits of sin have had the first and best chance. It makes religion a thing of life rather than a preparation for death. If it were not a possibility, we would surely conclude that the religion of the Bible were an after-thought, 
and not entirely adjusted to human problems and human nature. The child is God's own from the foundation of the world; it is hard to believe that he could be God's only by some strange working against his nature, and subsequent to childish development, and at the best God could only have a mere remnant of his life.

Believing earnestly, as we do, in the normality of childlike religion, we nevertheless believe that the growing youth is to have some crises in his development. He may proceed gradually on the upgrade of life, when suddenly a new vision, a wider horizon, opens upon him, with greater opportunities, new privileges, and heavier responsibilities than those before known. Will he enter upon this larger day? The decision is not the question of conversion from a life of sin; but it is a question of the further progress or retrogression of life. "We have failed to make the proper" distinction between conversion and the coming into clearness of spiritual consciousness. This latter is necessary in the case of every person, but conversion is necessary only in the case of those who have fallen away from God through voluntary sin. Failing to make this distinction, we have fallen into the error of regarding certain experiences which come naturally to children in their moral and spiritual development as conversion, where in reality it is only what may be called 'the spiritual awakening,' that is a necessary incident to the spiritual life, when that which lies latent and undefined in the mind becomes active and 
definite. This corresponds in the spiritual life to what occurs ordinarily in the mental life. The development of the mind in any large way requires a mental a wakening when the mind becomes eager and questioning and hungry; when its eyes are opened and it begins to look out upon the world of things with interest and strong desire for knowledge. To the soul also must come a time when it awakens from vague into distinct consciousness of God, when its spiritual cravings take definite direction, when in fact the soul becomes conscious of itself and its moral power. Such an awakening should be expected in the history of every child, but it may have nothing in common with what we know as conversion or regeneration in an adult." (Dr. McFarland: "Preservation versus The Rescue of the Child," 21.) Even to the Christian child the adolescent period is likely to precipitate such a crisis, and its decision is fraught with grave consequences. A quotation from Campbell Morgan will cover this point and much that we have already contended for. "It is a great mistake to think of man as made, and then put in some position, where he may rise or fall, according to the capacity of his own personality. It is rather to be remembered that he was cre- ated in the image of God, and then put in the probationary position, through which he has to pass to some larger form of existence, if his life were lived in union 'with God who created him." ("Crises of the Christ," 28.)"

We are presenting no recent or strange doc- 
trine in holding to the acceptable relation of children to God. As good a theologian as Dr. W. F. Warren, as fraternal delegate from the General Conference of the Methodist Episcopal Church to the British Conference in 1882, in ringing words presented the following ideal: "What, then, is the type higher and better? . . . It is the type which does not demand . . . that the first years of every life shall be given to the service of $\sin$ and Satan; it is the type which comes of making the resources of divine grace equal to all the necessities of childhood; it is the type which comes to light in the Christian household when the child of many prayers and of intelligent Christian nurture yields to the drawings of the Holy Spirit so early and so sweetly as never in later life to know when it began to love God and to lead a life prayerful and Christian and of ever-growing beauty and strength. . . Rare as its actualization may be, it is the type which God by His Holy Spirit is evermore trying to actualize in every Christian home. . . . If the Methodism of the future is to be equal to her providential call and mission in this respect, she must not permit the exponents of a catastrophic piety to hide her loftier and better ideal. . . . She must acknowledge those whom God acknowledges, and, like her Lord, re- ' buking all interdiction, she must take these little ones in her arms and bless them, saying, 'Of such is the Kingdom of heaven.' . . . In our conception there is perfect purity for the vilest sinner. 
But if for the vilest sinner, how much more for the artless spirit of the little child, who, under the influences of a Christian nurture at the very dawn of the spiritual consciousness, trustfully yields himself up to the Spirit's purifying touch." (The Christian Advocate, N. Y., Aug. 10, 1882.)

Dr. Arthur H. Goodenough says: "To make the child a Christian is not our business. Our work is to see that it never ceases to be a Christian. The thing needed for the child is not conversion, but atmosphere, example, nurture, encouragement. The child is in the Kingdom. It is the Father's own, whom Jesus loved and blessed. The Master pointed to the child as the pattern of what we ought to be; and yet some of our brothers still insist that the children of their flocks must go to the altar, and in the one way, their way, the narrow way, the only way, tell God what great sinners they have been. To keep a child out of Church membership because this is not done is unwarranted and wicked; and yet this very thing is occurring all the time. The children, sweet and beautiful, are being driven away from the Church home and shelter and help just because their parents will not consent to their going through the same forms of confession and repentance that are expected of hardened sinners. The parents are right, the Churches are wrong. Such conduct is cruel to the children and must be displeasing to the Master." (Zion's Herald, Nov. 11, 1903.)

Dr. Curtis, of Drew Theological Seminary, 


\section{MORAL CONDITION OF THE CHILD}

says: "The child is in a spiritual condition which is the equivalent of the regenerated state." ("The Christian Faith," 437.)

Stanley Hall says : "The Lutheran children do not look forward to conversion. If they have been baptized in infancy and daily nurtured, they must not be assumed to be unregenerate but as already in a state of grace. The germs of a spiritual life were early planted and have grown with their growth, and they need no violent change or drastic religious experience. Religion is a growth, not a conquest; but adolescence is the critical season of development, during which special care is needful." The above practice, it may be conceded, has not produced satisfactory results, and the spiritual condition of the Lutheran Church in Germany is one of the most discouraging facts in the world. To assign the reason we do not think it necessary to assume the doctrine of original sin in infants; but rather call attention to the fact that the spiritual tests are all perfunctory and mechanical. They should be spiritual and vital. The theory that we maintain is by no means a lazy theory of religion; a theory that assumes that all is well, and that, therefore, we need give ourselves no trouble, or that we may be satisfied with a few formal observances. It is just the contrary. It assumes the necessity of immediate and continuous religious instruction and care. This on the basis that the child is already in the Kingdom of God and needs Christian culture all the way to 
manhood. It shrinks from no test that is now applied to Christian people, unless the test be purely formal. Having done its work for the child, having brought it through the period when character is formed, it now challenges any tests that may demonstrate the presence of the Christlife within. If now it is demonstrated that it is devoid of that life, we would join with others in what are accounted revival lines and seek to secure the conversion of the soul to God. Our practical objection to the exclusive revivalistic method is that logically it would neglect the child through formative years, and then seek to bring him into the Kingdom by conquest, by revolution. This method we would commend only as a last resort.

We can not nullify absolutely the perils of freedom. After we have done all that human and even divine wisdom can suggest, there is ever a tribunal to which we must submit the results of our work. It is the august tribunal of the human soul itself. Man and God Himself must stand aside while this judge that never abdicates the throne renders the verdict. And yet religion is so reasonable, and sin is so suicidal and indefensible that the human soul, endowed with reason, should render such a verdict as we desire. We may do our work with a strong expectation of success, if we do it faithfully and well. Dr. S. P. Cadman has well expressed this confidence. $\mathrm{He}$ says: "The plane occupied at birth and during the earliest years should not be deserted, but main- 


\section{MORAL CONDITION OF THE CHILD}

tained. The spontaneous faith, the free and unmediated approach of the soul to its Creator, the faculties as yet uncrippled by the blows of sin, the warm and fragrant affection, the touching dependence on superior strength, all are hallmarks which are visible in the first years of this pilgrimage. And none can achieve a better fate than to turn back at eventide to the radiance that escorted his spirit into consciousness. How, then, do we deal with these morning flowers when they display their sweets, their gay and silken leaves unfold? Their spiritual experiences do not need the instilling of adult beliefs so much as the fostering of infant intuition. For these experiences precede statements of religious truth. They live in heaven before they conceive of heaven.

Bo glorious is their nature, so august

Man's inborn uninstructed impulses,

His naked spirit so majestical.

- . There is no powerful resistance in him which piety must overcome to obtain a lodgment. - . James Martineau says that 'if we place before our children the clear objects of faith, of truth in its beauty, and God in His holiness, they will respond. When we speak to them of the high deeds and splendid characters of the past, of the universe in which God lives and rules, of Jesus and His words and works, we may be assured the fruit will appear in due season. . . . Fasten his alert attention on the love and justice that permeate the universal frame and fill the activities 
of earth and boundless recesses of heaven; then leave these instructions to ripen in his susceptible and impressionable being, and fear not for the results." "' (Brooklyn Eagle.)

This view of the relation of the child to God seems to have been older than Christianity. The practices of the Jews would indicate that they. held their children to be members of the holy. nation, and that their religious rights should be strictly observed. Dr. Charles S. Robinson gives the following account of the care of Jewish children: "Counsels without number are given with reference to all the younger members of the family. They were to be solemnly dedicated under a prescribed ordinance. They were to be trained in all the matters of the ceremonial law. Historical and commemorative festivals were to be explained to their understanding, so as to be fixed in their intelligent recollection. They were not allowed to come under the contaminating influences which nurses of a different religion might possibly exert. As soon as they could speak they were taught to repeat sentences from the Scriptures. In the schools the law of Moses formed one of their common text-books. A sort of degree was to be taken at thirteen years old, and they received thereafter the name 'Sons of the Commandment.' And the settled rule in the Jewish nation was that as soon as they were able to walk up Mt. Moriah by holding on to their father's hands, they were to go up to Jerusalem to keep 


\section{MORAL CONDITION OF THE CHILD}

their first Passover. All along their growing years until they were mature they were held under strictest guardianship; and at last, when one had passed out of boyhood, he was brought officially before ten of the picked men and by solemn act was thrown on his own responsibility, his parents on that occasion soberly laying off the charge of their covenant and thanking God that they had been spared to complete his education, and now offer him to God and the nation." (Sunday School Times.) 


\section{CHAPTER XIV}

\section{WHICH ROAD?}

THERE are two roads in which children may be guided: the road of animal development and the road which uses physical powers but subordinates them to higher uses-the road of spiritual overdevelopment.

The history of our subject shows that there have always been two roads between which choice was made; but they have not always been distinguished as we would have them. The road of the spirit has been interpreted by the Puritanic thinker as one in which the flesh was regarded as in itself evil, and hence there was nothing to be done with it but to disregard it and deny its tendencies. This road has been broadly interpreted as asceticism. Of course, it never was a logical road, or one that was possible to vigorous men. The consequence has been that there was ever a rebellion against its standard by normal people and a self-depreciation by those who, accepting the standard as right and divinely imposed, never could live up to it.

Our own day is seeing the opposite extreme. The study of nature is largely a study of physical nature. Its impulses and tendencies are be- 
ing set forth so as to be well understood. It is not this positive work which we wish to question. The point of danger is that the physical nature is not being studied sufficiently in the light of its purpose or intended service. If it be regarded as ultimate, then we have as the object of human life the activities of the animal or physical nature. Johnson the pugilist would represent civilization's climax. This is the point at which the roads may divide. Against the culture and perfection of the physical nature we have no word of objection; but now we ask, What next? There are two distinct goals from this point. One is the physical only; the other is the perfected physical as the efficient instrument of the spiritual. Upon the choice of the goal to be aimed at will depend the choice and direction of future activities. One course is : having found out what the physical demands, supply the child with that, without further solicitude or program. The other says: Having given reasonable attention to physical development, what now are the demands of the spiritual nature which represents the ultimate self? The answer to this question must be determinative of the course taken. It is not demonstrable that the physical being requires all the resources of a normal life. It is rather true that the physical itself has a better development when it is used as a means, an instrument, a servant of the higher life. That is a better body which is under the control of a moral purpose than that which has no life in 
view beyond its own. The man with a spiritual purpose may have better health and live longer than the man who lives only to cultivate the physical. Thus we believe that the dominance and the subordination of the physical may be thoroughly harmonized as a method of normal life for both.

So we plead for the reinstatement of the spiritual as a program of life. We plead for the guidance of parent and teacher, following their conviction as to what is good for the young life rather than the control of the non-moral and uninstructed inclinations of boys and girls as to what should be the discipline of their life. The pendulum of control has swung too far toward the impulses of nature. In doing so it has missed its way and will never reach the goal of life. Inclination, as expressed in youthful life, is not always the same as nature's course. What children clamor for is not always and, after its course has been followed for a time, is seldom the demand of nature for their true development. Parents should know the laws of the child-nature and act accordingly; but in so doing they must not mistake the requests of the child as being the statement of those laws. Children may know what they want; but their wants are seldom under the control of a broad life-program. Parents are better able to arrange that. To allow mere clamor to change their course from the known good to the known evil is inexcusable weakness, however insistent the commotion, 


\section{MORAL CONDITION OF THE CHILD}

and the fruitage for parent and child will be as bitter as if the course had been adopted from sheer evil purpose. When the request is based in a natural demand of nature it should be acceeded to, but not always in the form which the child has urged it. Young people need social life. They should have it. The gratification of this need has in it the weal or the woe of the child. The easy way of providing for it is to turn children out into the street. In the case of boys this is the course in many cases. In the unwillingness of parents to pay the price of a better way lies more danger to our future than there is in all the battleships of all our possible national enemies. The other way is the creation of social life in the home, where it may be guided to high ends. This is costly. It wears out the carpets and mars the furniture. But there is more reward, greater dividends in saving boys and girls than in saving carpets.

A mother sometimes says: "I did not believe my boy ought to go out this evening; but he pleaded so hard that I let him go." That is an illustration oft repeated in families in which spiritual guidance loses its grip and lawless inclination takes the reins. This course is assumed as 'defensible by many people under the pressure of present-day tendencies-the tendency of finding what the animal wants, and giving it that. If this is correct theory, then the assumption that human beings are moral and that moral control is the 
highest expression of life, is unfounded. The recognition of the demands and laws of the physical life is one thing; the abdication of moral control is quite another. To observe natural obligations and conform to them by no means requires that the direction of the personality should be turned over to passions which are too blind even to seek their own good, to say nothing of the good of a spiritual nature to which is given the insight and the responsibility for the present and eternal guidance of the whole being. The expansive power of steam turns the propeller and drives the ship through the sea. Disregard of its power would lead to an explosion; failure to conserve it would allow it to dissipate in the air, and the ship without pushing power would be pounded to pieces by the merciless action of the waves. But it would be just as fatal to start the engine and leave it run with its mighty propulsion without a pilot to guide it. It would surely find the rocks and destroy all. So the passions of our nature make us go; but the reason, as a pilot, must steer the course, avoiding the rocks and finding the harbor.

In making this plea for the over-guidance of the spiritual, however, we express no sympathy whatever for that inattention to the whole nature of the child which is so often displayed. Let us remember that "that is not first which is spiritual, but that which is natural; and afterwards that which is spiritual." Every life must root itself in the physical. No life can be normal which ignores 


\section{MORAL CONDITION OF THE CHILD}

the animal nature, the physical basis, and spreads its tiny tendrils in the pure air of spirituality. We may not be able to fathom the divine reason for the complexity of our nature; but we may recognize it as a fact invincible, and believe that it represents a plan of God and can not be successfully annulled or obstructed. We start with the physical. The problem is, how to direct the total personality up into the spiritual, as representing the final expression of our being. The physical is first, but it should not be last. The moral problem of life is to achieve such a mastery of the physical, such a subordination of the physical, such a crucifixion of the physical, when it presents an unyielding obstacle, and withal such a ministration of the physical as shall make life in its outcome a total spiritual victor, and the physical shall drop away at last, bearing our kindliest memories, having accomplished its temporary purpose. Surpassingly happy is the man who, as he bids it farewell, can thank God for the gift and realize that its impulses and passions have not engulfed his real and final self, but have had a distinct and essential part in his final completeness.

A mother, a father, should know the nature of their child through and through. They should know boy-life. If they try to build a spiritual life without regard to all the realities that are in the problem; if they talk only of spiritual things, frowning upon the intrusion of the natural and passionate; if they seek only a certain high ex- 
pression of the spiritual nature; if they ignore the fact of social inclination, physical activity, or even sexual impulses, the danger is that their child will develop, so far as their knowledge goes, a crust of artificiality to which the real life within may be unrelated. Know your children. Do not be content with knowing only what you would like them to be. Encourage them to open to you their desires, their inclinations, their temptations, their conflicts. Work from the vantage point of that knowledge, however heartbreaking may be its revelations. You can do more when you see than when you do not. You can accomplish more when using knowledge than when you are operating only with ignorance as an instrument. How many cases we have known where a continually pious conversation of parents with their children caused them to cultivate a suavity of manner, a guardedness of expression, a piety of apparent belief and life because they had learned that nothing else was received without reproof or distaste! Such children learn to be secretive, to live a life they never reveal to their parents; a life in which real confidences are not given; a veneer life; an unreal life the reason for which is not seated in conviction nor anchored in resolution. This is a road which many religious parents are tempted to travel. The revelation of the reality underneath after a while is a painful tragedy.

In morals as in biology there is a law of the "Survival of the Fittest." It does not mean that 
the best will survive; it means that that survives which best fits into the environment. Hence it often indicates degeneration as well as, under other circumstances, progress. We control the survival of the best by our control of the environment. "Nature never gives a final verdict in favor of good or bad, but only and always in favor of the fit. Let the conditions change, so that rapacity fits them better than righteousness, . . . and the thing we call high will go before the thing we call low. . . These laws enthroned and dethroned the civilization of the past: they have enthroned and may dethrone us. But this end is not inevitable, since man-and this is his great character-not merely reacts on his environment, as all creatures must, but can create and re-create it. The business of eugenics or race-culture is to create an environment such that the human characters of which the human spirit approves shall in it outweigh those of which we disapprove. Make it fittest to be best, and the best will win-not because it is the best, but because it is the fittest: had the worst been the fittest it would have won." (Saleeby: "Parenthood and Race Culture," 53.)

In the struggle of the different elements in human nature we may arrange for the mastery (survival) of the higher or the lower, according as we create surroundings in which the higher or the lower will be brought most into exercise. In an atmosphere of physical ideals we may expect physical activities to grow large and strong, and spir- 
itual activities to dwindle and slink out of sight, because they are uncalled for and unappreciated. The atmosphere is created by the conversation in the family circle, the books on the shelves, the papers on the table, the visitors in the home, the invited companions of the children, the home extended in school and Church, and the undercurrents of ambitions and ideals which dominate and spontaneously come to expression in all the offguard moments of life. Keep thy home with all diligence; for out of it are the character issues of thy children-is a good modern version of one of the profoundest sayings in literature. One author makes the sweeping statement that "all of the environmental conditions of the growing youth are faulty, save - in the case of the fortunate ones - the moral atmosphere of a proper home, the great inhibitor of all moral evils." (Lydston: "Diseases of Society," 403.) 


\section{CHAPTER XV}

\section{SUMMARY}

LET us connect our chain into three well-defined links. 1. The genesis of the child is not from an act inherently sinful. It is necessary to call distinct attention to the importance of this fact, because logically it is the source of the doctrine of the inherent sinfulness of human nature. That the child is a product of sinful passion has been the assumption of Christian thinkers at least since the time of Augustin, who had so much to do with the formation of Christian doctrine. We are the more surprised at the age-long dominance of this assumption when we remember that the first positive command in the Bible was to multiply and replenish the earth. We remember also that in this act God takes man into partnership in the introduction of human beings into what we believe is the beginning of an eternal career of communion with Himself. It is surprising that we should regard God's part in this act as more worthy of Him than the speaking into existence of a material world, and at the same time should regard man's part as inherently and invincibly evil. God has nowhere bestowed upon man greater dignity than 
when He permits him to open the gate of life to an eternal spirit. It but manifests the immeasurable destructiveness of $\sin$ when by misuse of this privilege man turns the gate of life into the gate of death. We must awaken more and more to a consideration of the ruin of society which is being wrought by the violations of sex relations. By it innocent and unsuspecting brides are subject to irremediable disease and measureless pain ; unborn children are consigned to degeneracy and human infamy, and civilization itself is endangered. But to find that the misuse of the highest human function leads to the greatest enormities of misery and shame, is to find as ever in nature that the worst is but the corruption of the best and is no argument against the spiritual normality of the origin of human life.

We are surprised, again, that a divinely implanted passion, for the existence of which none but God is responsible, should in its operation be regarded as always in opposition to the divine will, and that the ideal condition of human nature should ever have been considered as that in which this passion is forever negatived and destroyed. To allow this assumption to continue its dominance in religious circles is to carry on a continuous warfare against the scientific world, which knows, if it knows anything, that the reproduction of individuals of the race is a biologic virtue. We deplore this belief again because of its degradation of the marital life. Marriage is usually 


\section{MORAL CONDITION OF THE CHILD}

treated as a matter for jokes and never-ending suggestive allusion. Courtship is surrounded with an atmosphere of dissipation and frivolity, instead of being the apotheosis of human relationship, as it should be. The biggest show of the season in many a town is a mock-trial in a breach-of-promise case promoted by a national fun-maker. If marriage be lifted up to its divine ideal, and the marital act be regarded as a response to a divine call, then we have the genesis of a human being lifted to a plane where sin has no normal place, and the whole doctrine of human depravity is left without any foundation except the abuse of God-given powers and the misuse of normal human function.

2. We have by no means eliminated moral human struggle. It remains just as strenuous and as fateful as ever. The struggle is still a struggle against $\sin$; but $\sin$ is differently apprehended. It has been considered as an inbred something, something that could never be eradicated until the God-given body was laid aside. Whatever mastery over self one acquired, whatever profession of victory one might make, the movement of fleshly impulse still existed, and this "movement" was believed to be essentially sinful. The doctrine of Christian perfection, under such an apprehension of sin, was an absurd claim, and the wail of all ages for personal holiness must forever continue until the earth history is concluded-there is no escape while we live in the body. If our view is correct, victory over sin is not only a possibility, 
but its non-attainment is a disgrace to every child of God. That victory may be attained while the flesh is exerting its everlasting impulsion toward gratification. "The fruit of the Spirit is selfcontrol," says Paul. The demand for this control is ever insistent, and, thank God! its possibility is within our reach!

3. The third link in our chain is the vitality of the family-life. We would, if power sufficient is given us, leave the impression upon every parent that infancy and childhood are as full of destiny to the child spiritually as the prenatal condition is physically. There are certain laws which the parent may use, as vital in sustaining and directing the moral quality of the life, as the laws of food and clothing are in directing and sustaining the physical life. Two of these factors are known as Imitation and Authority. The child is so made that he will imitate us; thus God las put him within the absolute control of example. He can not help imitating us, and he has no action of the will during his early years which he may direct against this law of his nature. But as he does, so he is. To start with, he is, an empty vessel, intellectually and morally. Every time he acts he is dropping a little grain of selfhood down into this vessel, and this all before he has come to the place of moral choice.

In the years a little later, and on up to thirteen and fourteen years of age, he is so made that direction by another is to him normal. He 


\section{MORAL CONDITION OF THE CHILD}

is fitted to receive command without interruption or disturbance of his proper development. This authoritative direction should be supplied to him just as food is supplied to his body, as unswervingly as the planets in their course. So, if we will give him proper direction, we will secure from him proper action. And still, as he acts so he is. The vessel is not yet full. Every time he acts aright he is still dropping a grain of selfhood down into his character, against the day when he must take up moral self-direction for himself.

On authority as a fundamental law of being, Dr. Charles H. Parkhurst has the following thoughtful words: "Parents do well to foster in their children a liberty-loving spirit; but liberty is a positive matter, and not a negative, and consists not in what we renounce but in what we espouse. We emancipate ourselves, not in what we tear ourselves lose from, but in what we tie ourselves up to; and the only liberty fit to be set up in the home, or anywhere else, as an object of admiration and an end to be attained, is the liberty that fulfills itself in zealous adherence to external authority, not in its rejection. Liberty is a genius for obeying, and consists not in our successful escape from ordinance, but in the graceful facility with which we are able to execute it. It is the liberty to do consciously what the flower does unconsciously when, without constraint and without revolt, it accomplishes the 
vegetable destiny decreed for it; what the star does unconsciously when, unhasting and unresting, it beamingly runs the road laid down for it."

To grasp control of the will of the child was one of Susannah Wesley's earliest tasks, "because," she continues, "this is the only strong and rational foundation of a religious education, without which both precept and example will be ineffectual. But when this is thoroughly done, then a child is capable of being governed by the reason and piety of its parents, till its own understanding comes to maturity and the principles of religion have taken root in the mind." (Stevens: "Hist. of Methodism," I, 55.) This subjection of the will of the child is often criticised as if it were breaking the will of the child. It is no more breaking the will than is the staking up of a vine the breaking of the vine. It is rather giving direction to the will, governing it in harmony with the laws of its own nature, so that when it comes to its own independent expression it will not break against the unyielding forces of nature and society about it.

It is only necessary further to remark that these two laws, imitation and authority, which are to be used by parents, may also be used by others. So that there is a negative or defensive duty which we owe the child. We must keep him from those sights and those directing and suggesting influences which are evil and will produce the evil 


\section{MORAL CONDITION OF THE CHILD}

action. If this in its completeness is an impossibility, it at least is an ideal, and its violation is a peril to the extent to which it may proceed. This empty vessel can be filled with vice as inevitably as it can be filled with virtue by the operation of the same laws. 



\section{University of California}

SOUTHERN REGIONAL LIBRARY FACILITY

405 Hilgard Avenue, Los Angele to library

Return this material to the which it was borrowed.

$$
\text { from which it }
$$


UC SOUTHERN REGIONAL LIBRARY FACILITY A 000670075 , 
